
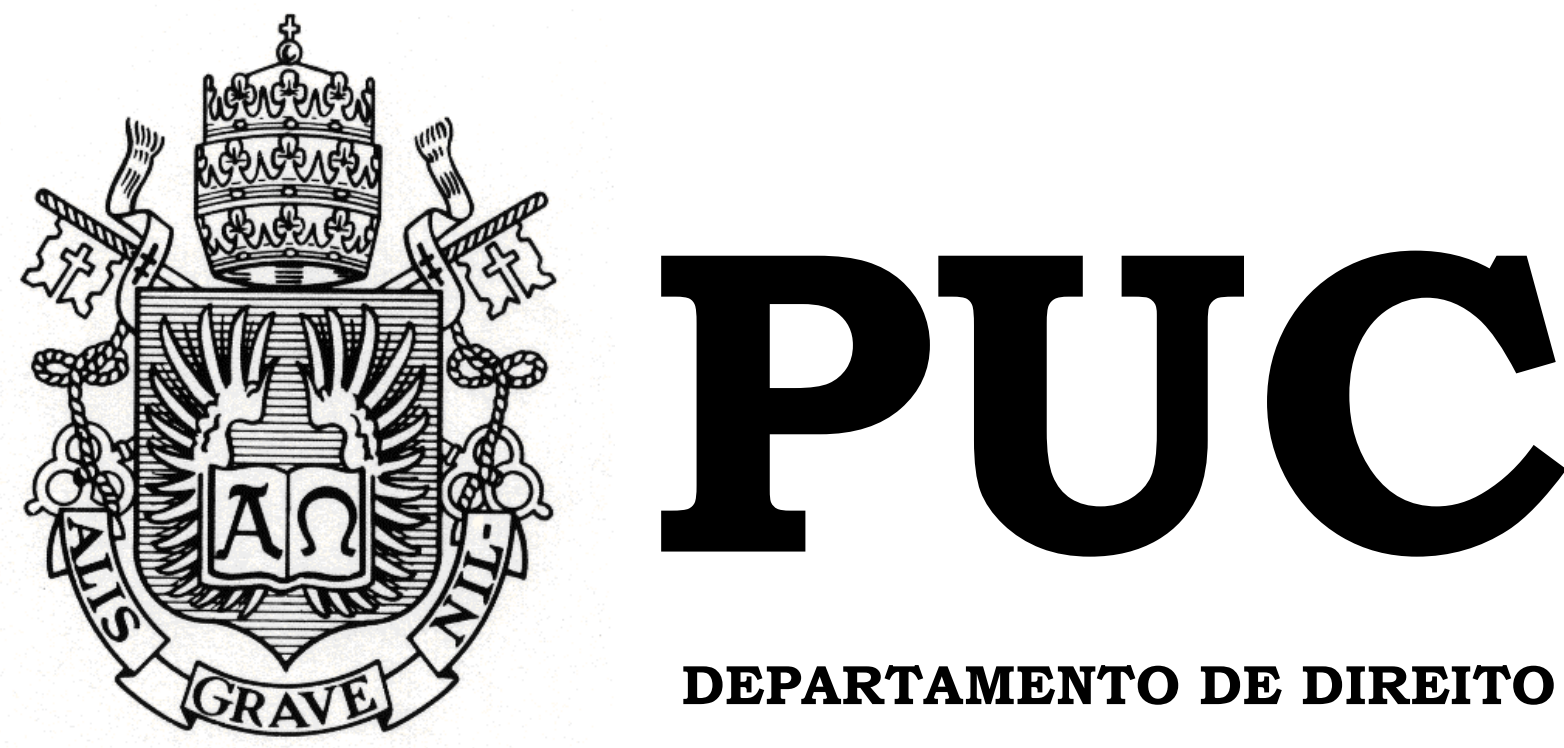

DEPARTAMENTO DE DIREITO

Os shark repellents à luz do mercado de capitais brasileiro: proteção ou entrincheiramento?

por

Elmiro Chiesse Coutinho Neto

ORIENTADOR: Francisco Antunes Maciel Müssnich 2016.1

PONTIFÍCIA UNIVERSIDADE CATÓLICA DO RIO DE JANEIRO

RUA MARQUÊS DE SÃO VICENTE, 225 - CEP 22453-900

RIO DE JANEIRO - BRASIL 


\title{
Os shark repellents à luz do mercado de capitais brasileiro: proteção ou entrincheiramento?
}

\author{
por \\ Elmiro Chiesse Coutinho Neto
}

Monografia apresentada ao

Departamento de Direito da

Pontificia Universidade Católica do Rio de Janeiro (PUC-Rio) como requisito parcial para obtenção do título de Bacharel em Direito.

Orientador: Francisco Antunes Maciel Müssnich 
Poison Pills - "É semelhante à venda de um terno de casimira para alguém que mora em Teresina, sob os argumentos de que ele atende suas demandas, além de ser a última moda, para depois esse pobre usuário descobrir que não consegue sair da roupa, de tão bem talhada que foi”.

(ARAGÃO, Paulo Cezar. Desafio é não estragar a Lei. Revista Capital Aberto. Setembro de 2010) 


\section{Agradecimentos}

Aos meus pais e irmãos, por todo o apoio e carinho.

A todos os ex-integrantes do Gabinete da Presidência da CVM, em especial, à Julia Franco e à Camila Pantera.

Adicionalmente, gostaria de agradecer à ex-Diretora da CVM, Ana Novaes, com quem também tive o privilégio de trabalhar.

A todos que fazem parte da equipe de Mercado de Capitais do Veirano Advogados, em especial, ao Julio Dubeux, Guilherme Monteiro, Vitor Rozenthal, Roberta de Carolis e Pedro Figueiredo, bem como meus colegas de estágio Eduardo Campello e Bianca Napoli.

Por fim, ao meu professor e orientador Chico Müssnich, por todo o aprendizado e inspiração. 


\section{Resumo}

Coutinho Neto, Elmiro Chiesse. Os shark repellents à luz do mercado de capitais brasileiro: proteção ou entrincheiramento? 137 p. Monografia (Graduação em Direito) - Pontifícia Universidade Católica do Rio de Janeiro: Rio de Janeiro, 2016.

O presente trabalho tem como primeiro objetivo analisar as formas de exercício do poder de controle nas sociedades por ações, bem como o instituto das ofertas públicas de aquisição de controle, a fim de estabelecer alicerces que serão importantes para o desenvolvimento desta monografia. Além disso, serão examinadas as diferentes espécies de mecanismos de proteção contra a tomada hostil de controle de companhias, com destaque para as Brazilian pills. Adicionalmente, estudar-se-á a jurisprudência da Suprema Corte de Delaware, assim como da Comissão de Valores Mobiliários (CVM) acerca do tema, a fim de proporcionar um estudo à luz do direito comparado. Por fim, a partir da análise da pesquisa empírica realizada no âmbito deste trabalho (Anexo I), realizar-se-á um exame crítico acerca da aplicação dos mecanismos de proteção e suas implicações no âmbito do mercado de capitais brasileiro.

Palavras Chave: Direito Societário - Mercado de Capitais - Oferta Pública de Aquisição de Controle - Mecanismos de Proteção contra a Tomada Hostil de Controle - shark repellents - Brazilian pills. 


\section{Sumário}

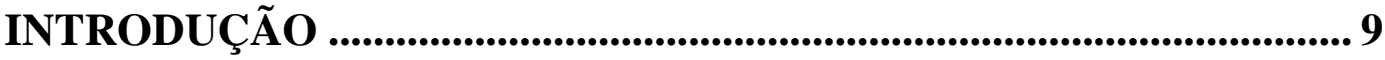

CAPÍTULO 1 - O PODER DE CONTROLE NAS COMPANHIAS .. 15

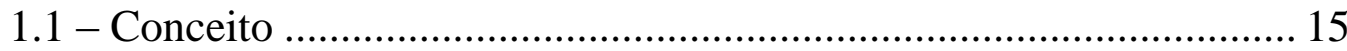

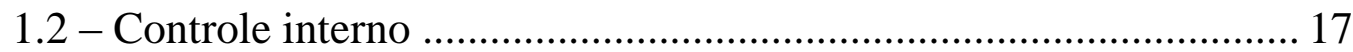

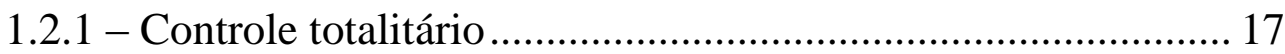

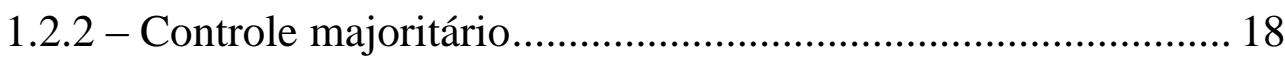

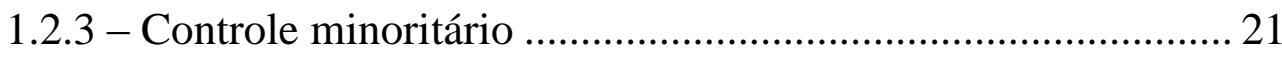

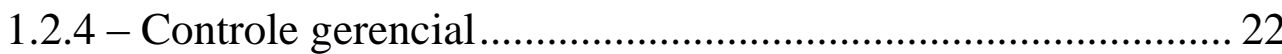

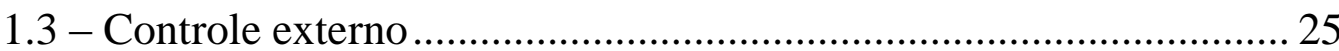

CAPÍtUlO 2 - A OFERTA PÚBLICA DE AQUISIÇÃo DE CONTROLE ...................................................................................................... 27

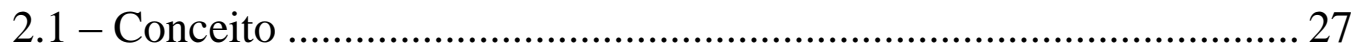

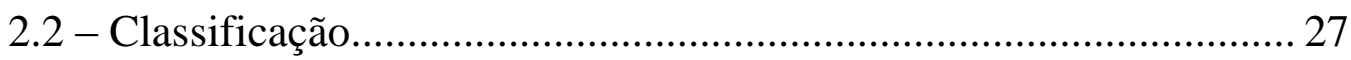

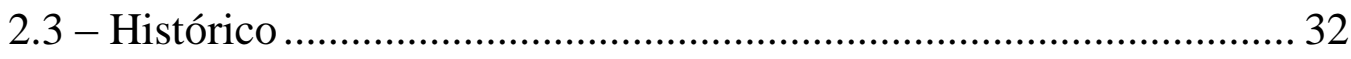

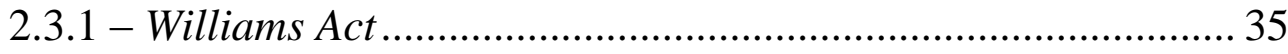

2.3.2 - Securities Exchange Act of 1934, Sections $13(d)$ e 14 (d)..... 36

2.4 - O pioneirismo do advogado Joseph Flom......................................... 39

2.5 - As ofertas coercitivas sob a ótica da teoria dos jogos...................... 42

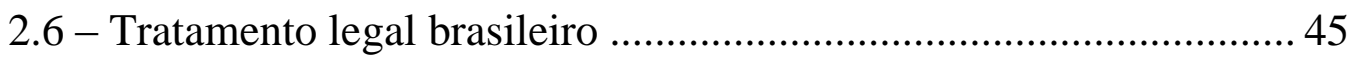

CAPÍTULO 3 - OS MECANISMOS DE PROTEÇÃO CONTRA A TOMADA HOSTIL DE CONTROLE .................................................... 49

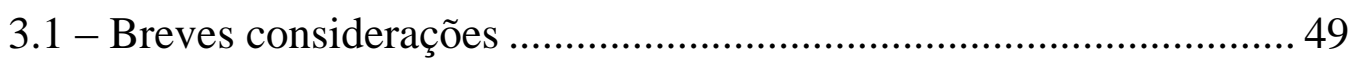

3.2 - Pílulas de veneno (poison pills) ........................................................ 50

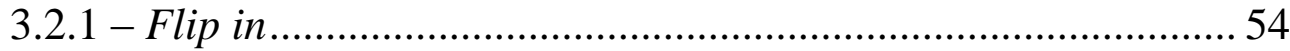

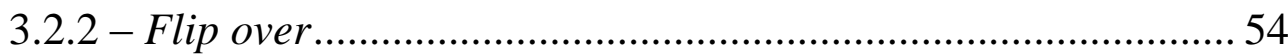

3.3 - Cláusulas de proteção à dispersão acionária (Brazilian pills) ......... 55

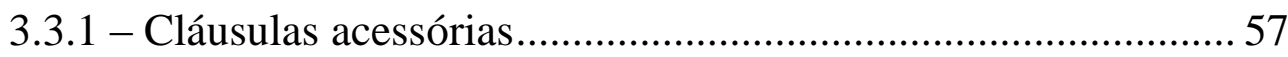

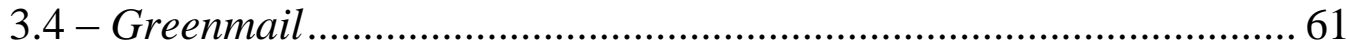

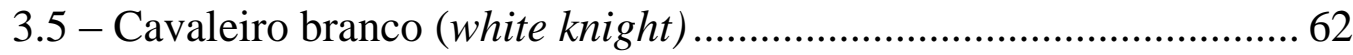

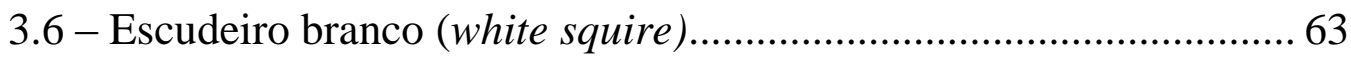

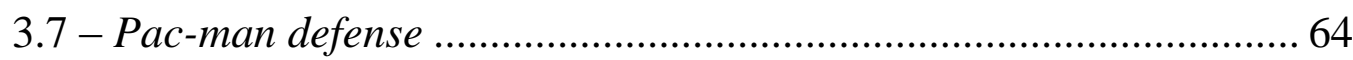

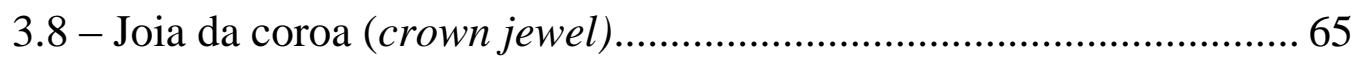




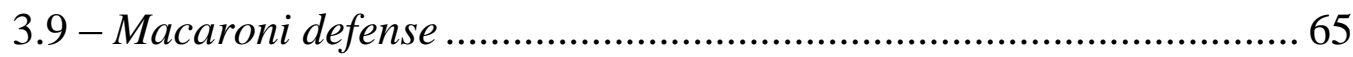

3.10 - Paraquedas dourado (golden parachute).......................................... 65

3.11 - Conselho de administração escalonado (staggered board)............ 66

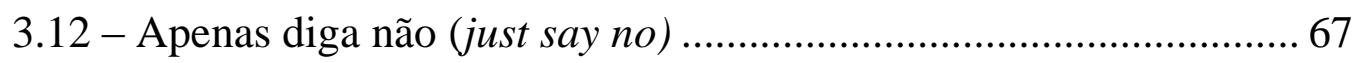

CAPÍTULO 4 - OS MECANISMOS DE PROTEÇÃO NOS ESTADOS

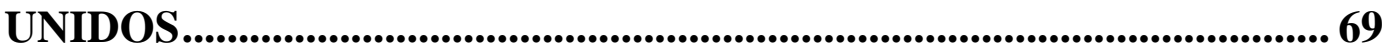

4.1 - A importância do estado de Delaware .............................................. 70

4.1.1 - A business judgment rule como salvaguarda dos

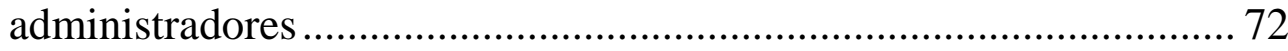

4.1.2 - Casos da Suprema Corte de Delaware ...................................... 74

4.1.2.1 - Unocal Corp. v. Mesa Petroleum Co.......................... 74

4.1.2.2 - Moran v. Household International ............................... 77

4.1.2.3 - Revlon, Inc. v. MacAndrews and Forbes Holdings, Inc. 81

4.1.2.4 - Paramount Communications, Inc. v. Time, Inc. ......... 84

4.1.2.5 - Paramount Communications v. Qvc Network.............. 86

4.1.2.6 - Unitrin, Inc. v. American General Corp..................... 88

\section{CAPÍTULO 5 - OS MECANISMOS DE PROTEÇÃO NO BRASIL .93}

5.1 - A Comissão de Valores Mobiliários (CVM) .................................... 93

5.1.1 - Decisão do Colegiado de 14/04/2009 - Memorando sobre as Brazilian pills de Marcos Barbosa Pinto e Otavio Yazbek ................. 95

5.1.2 - Parecer de orientação CVM n ${ }^{\circ}$ 36/09 .................................... 96

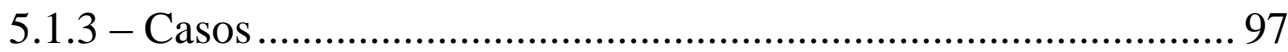

5.1.3.1 - Mittal Steel Company N.V. e Arcelor S.A. ................. 97

5.1.3.2 - Reorganização societária de Datasul S.A. e Totvs S.A.; Construtora Tenda S.A. e Gafisa S.A.; e Company S.A. e Brascan Residencial Properties S.A. (memorando para a SRE, enviado pela GER-1 em 17/09/2008, referente ao Processo RJ n ${ }^{\circ}$

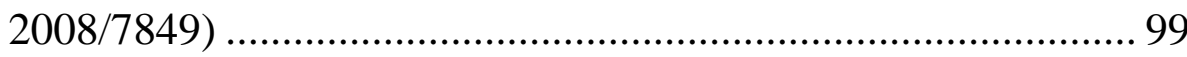

5.1.3.3 - Processo Administrativo Sancionador CVM $\mathrm{n}^{\circ} \mathrm{RJ}$

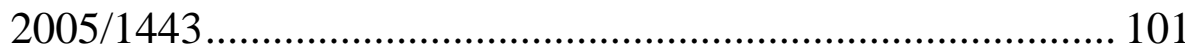

5.2 - A Bolsa de Valores de São Paulo (BM\&FBovespa)....................... 101

5.2.1 - Diagnósticos da América S.A. e Cromossomo Participações II

S.A. (Caso da Câmara de Arbitragem da BM\&FBovespa) ............... 102

5.2.2 - Regulamento de Listagem do Novo Mercado ....................... 104 
CAPÍTULO 6 - OS DEVERES DOS ADMINISTRADORES NA LEI

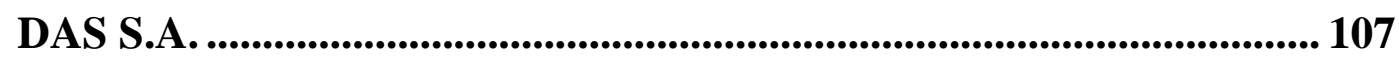

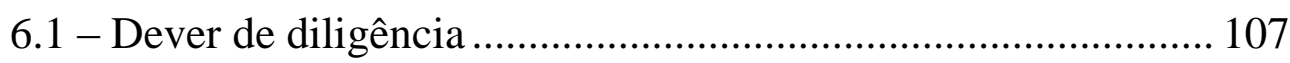

6.1 .1 - Dever de se informar................................................. 108

6.1.2 - Dever de vigilância ....................................................... 109

6.1.3 - Dever de investigar ...................................................... 109

6.1.4 - Dever de intervir ............................................................ 109

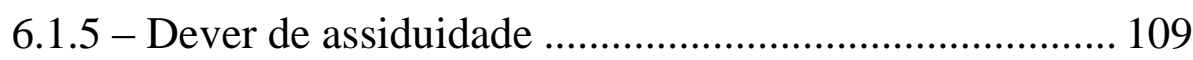

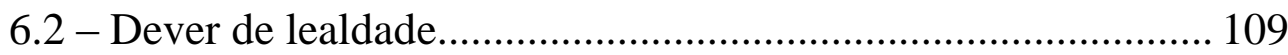

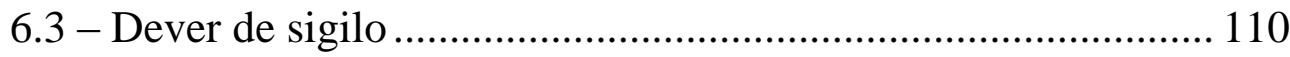

6.4 - Dever de informar ................................................................. 112

CAPÍTULO 7 - EXAME DA APLICAÇÃO E PERTINÊNCIA DOS MECANISMOS DE PROTEÇÃO NO BRASIL ...................................... 114

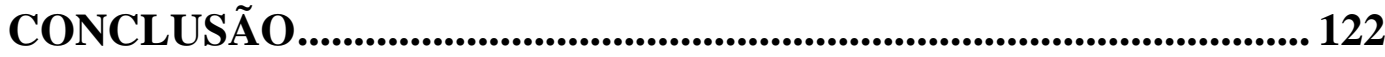

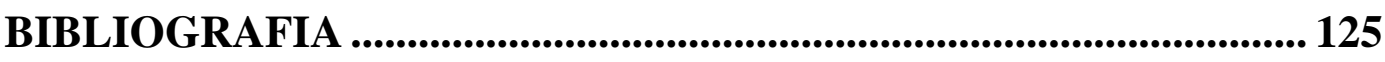

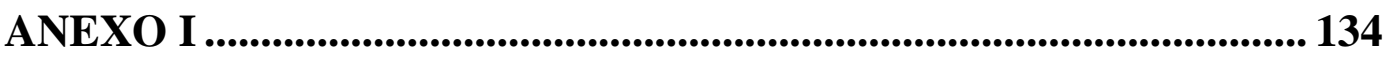




\section{INTRODUÇÃO}

O início do século XXI foi marcado por um período de intenso desenvolvimento do mercado de capitais brasileiro. ${ }^{1}$ Nessa época, houve um aumento significativo no número de aberturas de capital para fins de realização de Initial Public Offerings (IPOs) ${ }^{2}$. Isso se deu, dentre outros motivos, pelo crescimento da economia mundial anterior à crise de 2008, e pela criação dos segmentos especiais de listagem da BM\&FBovespa em $2000 .^{3}$

As companhias que aderem a esses segmentos proporcionam maior proteção aos seus acionistas, sobretudo aos minoritários, tendo em vista a adoção em suas estruturas societárias de regras mais rígidas do que aquelas previstas na legislação aplicável. ${ }^{4}$ A BM\&FBovespa visou, com isso, conferir ao mercado ambientes de negociação que atraíssem o interesse dos investidores e que, ao mesmo tempo, valorizassem as companhias neles listadas. ${ }^{5}$ O Regulamento do Novo Mercado, por exemplo, estabelece regras que visam a maior liquidez das ações, dentre elas, a obrigação de manutenção de um free float de $25 \%$ do capital social ${ }^{6}$.

Nesse contexto de crescimento e mudança da realidade do mercado, o Brasil aos poucos passou a vivenciar o fenômeno da dispersão acionária

\footnotetext{
${ }^{1}$ NASCIMENTO, João Pedro Barroso do. Medidas Defensivas à Tomada de Controle de Companhias. São Paulo: Quartier Latin, 2011. p. 25.

${ }^{2}$ Segundo dados fornecidos pela Bolsa, foram realizadas 7 ofertas iniciais em 2004, 9 em 2005, 26 em 2006 e 64 em 2007, quando o mercado atingiu seu recorde. Já a partir de 2008, os números

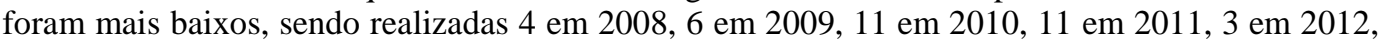
10 em 2003, 1 em 2014 e 1 em 2015. Disponível em: <http://www.bmfbovespa.com.br/pt$\mathrm{br} /$ mercados/acoes/ofertas-publicas/ofertas-publicas.aspx?idioma=pt-br $>$.

${ }^{3}$ PEREIRA, Atademes Branco; TREIGER, José Marcos. Por que abrir o capital? In: SIQUEIRA, Marcelo; PEREIRA, Atademes Branco; TREIGER, José Marcos (Coord.). Brasil S/A: Guia de Acesso ao Mercado de Capitais para Companhias Brasileiras. Rio de Janeiro: RR Donnelley Financial Comunicação Corporativa, 2014. p. 15.

${ }^{4}$ Disponível em: http://www.bmfbovespa.com.br/pt-br/servicos/solucoes-paraempresas/segmentos-de-listagem/o-que-sao-segmentos-de-listagem.aspx?idioma=pt-br.

${ }^{5}$ EIZIRIK, Nelson; GAAL, Ariádna B.; PARENTE, Flávia; HENRIQUES, Marcus Freitas. Mercado de Capitais - Regime Jurídico. 3ed. Revista e ampliada. Rio de Janeiro: Renovar, 2011. p. 250-251.

${ }^{6}$ MÜSSNICH, Francisco Antunes Maciel; LOBÃO MELO, Vitor de Britto. Análise Prática e Considerações sobre a realidade e a aplicação das medidas de proteção à tomada de controle nos estatutos sociais das companhias abertas brasileiras (Brazilian Pills). In: SILVA, Alexandre Couto (Coord.). Direito Societário - Estudos sobre a lei de sociedades por ações. 2013. Editora Saraiva. p. 255-256.
} 
seguindo, ainda que de forma incipiente, a experiência de mercados de capitais mais desenvolvidos, como Estados Unidos e Inglaterra. ${ }^{7}$

Nos Estados Unidos, BERLE e MEANS realizaram um estudo ${ }^{8}$ sobre a separação entre propriedade e controle das companhias norteamericanas. Segundo os autores, com o processo de concentração empresarial verificado nos Estados Unidos, ocorreria uma crescente dispersão da propriedade, passando os proprietários - acionistas - a ocupar uma posição cada vez mais passiva nas companhias, enquanto que os administradores passariam a deter o controle de fato:

Accompanying the concentration of economic power, growing out of it, and making it possible, has come an ever wider dispersion of stock ownership. This in turn has brought about a fundamental change in the character of wealth, - in the relation between the individual and his wealth, the value of that wealth and the nature of property itself. Dispersion in the ownership of separate enterprises appears to be inherent in the corporate system ${ }^{9}$.

Verifica-se pelo estudo de BERLE e MEANS que a forma de controle predominante entre as companhias norte-americanas seria aquela denominada de controle gerencial (management control), ou seja, aquela em que não há acionista controlador definido, tendo em vista que $44 \%$ das maiores 200 empresas estariam controladas pelos administradores; $21 \%$ mediante expedientes legais (legal device); $23 \%$ estariam sob controle

\footnotetext{
${ }^{7}$ Neste caso, vale considerar as ponderações de MUNHOZ sobre o sistema concentrado e diluído e os desafios do direito brasileiro acerca do tema: "O reconhecimento da predominância do controle concentrado impõe desde logo uma indagação: deve-se buscar a transformação da estrutura para a de controle diluído, sistema havido como superior por grande parte da literatura? A resposta, ainda que fosse positiva, levaria à adoção de posturas ingênuas e pouco efetivas. A transformação da estrutura de controle dominante em um determinado país não se faz apenas por meio da modificação das regras societárias, ainda que fosse possível aprovar tais modificações. Há uma série de outros fatores, de ordem econômica, social e política, que tornam a estrutura de controle presente em um dado momento histórico altamente resistente a mudanças. Prova disso é que o sistema de controle diluído, havido como mais eficiente, é dominante talvez apenas nos Estados Unidos e no Reino Unido." (MUNHOZ, Eduardo Secchi. Desafios do Direito Societário Brasileiro na Disciplina da Companhia Aberta: Avaliação dos Sistemas de Controle Diluído e Concentrado. In: CASTRO, Rodrigo R. Monteiro de; ARAGÃO, Leandro Santos de (Coord.). Direito Societário - Desafios Atuais. São Paulo: Quartier Latin, 2009. p. 153).

${ }^{8}$ BERLE, Adolf; MEANS, Gardiner. The Modern Corporation and Private Property. Harcourt, Brace \& World, Inc. New York. Revised Edition. 1967. First Edition 1932.

${ }^{9}$ Ibid. p. 47.
} 
minoritário (minority control); e os restantes sob administração judicial ou controle de acionistas majoritários ${ }^{10}$.

O fenômeno da dispersão acionária começou a se manifestar no Brasil após grandes mudanças ocorridas no mercado a partir de 2004, quando a Natura Cosméticos S.A. abriu seu capital, e ofertou publicamente ações de sua emissão no Novo Mercado. O sucesso da oferta da sociedade marcou o início de um processo de aberturas de companhias com controle similar no Brasil. A Natura trouxe também para a realidade do mercado a primeira previsão estatutária de cláusulas de proteção contra a tomada hostil de controle ${ }^{11}$.

Em 2005, a Lojas Renner S.A. também apresentou um fato até então inédito quando sua controladora, J. C. Penney, decidiu alienar o controle da companhia no mercado de forma pulverizada. Com a operação, a Lojas Renner se tornou a primeira companhia brasileira a ter efetivamente seu capital disperso, com mais de $90 \%$ das ações em circulação. Assim como a Natura, a Lojas Renner também incluiu uma medida de proteção em seu estatuto contra aquisições hostis de controle ${ }^{12}$.

Em 2006, a Perdigão S.A. também passou a ter seu controle difuso, e essa realidade permitiu que a Sadia S.A. realizasse uma oferta pública hostil para tomada de controle da companhia. No entanto, a operação foi inviabilizada com a recusa da oferta por mais de $50 \%$ dos acionistas da Perdigão. Ressalte-se que à época, a companhia também possuía uma previsão estatutária similar à da Natura e da Lojas Renner, embora não tenha sido utilizada. ${ }^{13}$

Nos Estados Unidos, muitas companhias adotaram medidas de defesa no momento da realização de IPOs. O entendimento de FIELD e

\footnotetext{
${ }^{10}$ Ibid. p. 109.

${ }^{11}$ PRADO, Roberta Nioac. Desconcentração do Poder de Controle e Poison Pills: Evolução no Mercado de Capitais Brasileiro. In: CASTRO, Rodrigo R. Monteiro de; MOURA AZEVEDO, Luís André N. de (Coord.). Poder de Controle e Outros Temas de Direito Societário e Mercado de Capitais. São Paulo: Quartier Latin. 2010. p. 384-385.

12 Ibid. p. 390-393.

13 Ibid. p. 393-398.
} 
KARPOFF é o de que administradores costumam aplicar tais medidas especialmente quando (i) suas remunerações são altas; (ii) as participações societárias são pequenas; e (iii) a supervisão pelos acionistas não gerenciais é fraca. Concluem, ainda, que os custos marginais das medidas acabam excedendo seus benefícios. ${ }^{14}$ Entende-se que, no Brasil, em alguns casos, as medidas adotadas no momento dos IPOs, em geral eram propostas por intermediários financeiros da oferta, tendo em vista o receio dos controladores de perderem o poder de domínio da companhia em uma eventual abertura de capital.

Não obstante as mudanças ocorridas no mercado brasileiro, o fenômeno da dispersão acionária apontado por BERLE e MEANS em 1932 ainda está apenas engatinhando no Brasil. Do mesmo modo, o controle gerencial ainda se verifica de forma muito embrionária, uma vez que são excepcionais os casos de companhias brasileiras desprovidas de controle acionário definido. ${ }^{15} \mathrm{De}$ acordo com a pesquisa realizada para este trabalho nos formulários de referência (FRs) de 130 companhias integrantes do Novo Mercado (Anexo I), verificou-se neste estudo que 92 apresentavam controlador definido, enquanto apenas 38 não apresentavam ${ }^{16}$.

Ressalte-se que à medida que a dispersão acionária cresce, as companhias tornam-se mais suscetíveis à tomada de controle, propiciando

\footnotetext{
14 "Many firms deploy takeover defenses when they go public. IPO managers tend to deploy defenses when their compensation is high, shareholdings are small, and oversight from nonmanagerial shareholders is weak. The presence of a defense is negatively related to subsequent acquisition likelihood, yet has no impact on takeover premiums for firms that are acquired. These results do not support arguments that takeover defenses facilitate the eventual sale of IPO firms at high takeover premiums. Rather, they suggest that managers shift the cost of takeover protection onto nonmanagerial shareholders. Thus, agency problems are important even for firms at the IPO stage.” (FIELD, Laura Casares; KARPOFF, Jonathan M. Takeover Defenses of IPO Firms. Journal of Finance, Vol. 57, No. 5, October 2002). Disponível em: <http://papers.ssrn.com/sol3/papers.cfm?abstract_id=286923>. Acesso em: 02/05/2016.

15 ZANINI, Carlos Klein. A Poison Pill Brasileira: Desvirtuamento, antijuridicidade $e$ ineficiência. In: ADAMEK, Marcelo Vieira Von. (Coord.). Temas de Direito Societário e Empresarial Contemporâneos. São Paulo: Malheiros, 2011. p. 262.

${ }^{16}$ Site da Comissão de Valores Mobiliários. Disponível em: <http://www.cvm.gov.br/>. Setembro de 2015.
} 
que terceiros interessados na aquisição o façam mediante operações realizadas em bolsa de valores ou mediante oferta pública de aquisição ${ }^{17}$.

Conforme se observa em estudo sobre o mercado de capitais brasileiro realizado por GORGA em 2009:

This analysis shows that changes in ownership patterns towards more dispersed ownership have produced important effects in companies' bylaws, prompting shareholders to adopt takeover defenses. However, these defenses may not correspond to an actual threat, as there still is a significant degree of concentrated ownership in most companies that could preclude takeover threats. ${ }^{18}$

Em outras palavras, ainda que haja um grau significativo de concentração acionária no Brasil, a pulverização acionária de algumas empresas tem produzido efeitos importantes no mercado, já que diversas companhias têm adotado cláusulas de proteção à dispersão acionária, de forma a tentar evitar a tomada hostil de controle. Essas cláusulas têm sido inseridas de forma generalizada nos estatutos sociais das mais diversas companhias.

Diante disso, esta monografia, primeiramente, visa estabelecer parâmetros para uma análise crítica sobre os efeitos da aplicação de tais mecanismos de proteção e sua pertinência no âmbito do mercado de capitais brasileiro. Para isso, serão conceituadas as diferentes espécies de controle adotadas pelas companhias, a fim de identificar quais estariam mais suscetíveis a uma eventual tomada de controle acionário.

Além disso, analisar-se-á o instituto da oferta pública de aquisição de controle, tendo em vista que este consiste no mecanismo mais tradicional para a tomada de controle, bem como arrolar fatos históricos que possam contribuir para a compreensão do tema.

\footnotetext{
17 NASCIMENTO, João Pedro Barroso do. Medidas Defensivas à Tomada de Controle de Companhias. São Paulo: Quartier Latin, 2011. p. 24.

${ }^{18}$ GORGA, Erica. Changing the Paradigm of Stock Ownership from Concentrated towards Dispersed Ownership: Evidence from Brazil and Consequences for Emerging Countries. Northwestern Journal of International Law \& Business. 2009. Disponível em: $<\mathrm{http}: / /$ scholarlycommons.law.northwestern.edu/cgi/viewcontent.cgi?article=1689\&context=njilb >. Acesso em: 16/05/2016. p. 483.
} 
Adicionalmente, analisar-se-á as diferentes espécies de mecanismos de proteção, com destaque para as cláusulas de proteção à dispersão acionária, também conhecidas como Brazilian pills.

E ainda, a fim de proporcionar uma análise à luz do direito comparado, estudar-se-á a jurisprudência da Suprema Corte de Delaware sobre o tema, tendo em vista a relevância da questão no ambiente norteamericano, além do posicionamento da Comissão de Valores Mobiliários com relação à matéria no Brasil.

Por fim, com base na aplicação prática dos mecanismos de proteção contra a tomada hostil de controle, observada por meio da pesquisa empírica realizada no âmbito deste trabalho (Anexo I), far-se-á uma análise crítica acerca da adoção de tais mecanismos no Brasil, observando os argumentos pró e contra sua adoção. 


\section{CAPÍTULO 1 - 0 PODER DE CONTROLE NAS COMPANHIAS}

\section{1 - Conceito}

BERLE e MEANS afirmam o seguinte sobre o poder de controle, levando em conta o fenômeno da separação entre propriedade e controle vivenciado nos Estados Unidos:

[...] we may say for practical purposes that control lies in the hands of the individual or group who have the actual power to select the board of directors, (or its majority), either by mobilizing the legal right to choose them-"controlling" a majority of the votes directly or through the selection of directors, but through dictation to the management, as where a bank determines the policy of a corporation seriously indebted to it. In most cases, however, if one can determine who does actually have the power to select the directors, one has located the group of individuals who for practical purposes may be regarded as "the control"19.

Especificamente no Brasil, a Lei das S.A., por sua vez, trata do poder de controle de forma detalhada em seu artigo $116^{20}$.

Pela leitura da Lei das S.A., observa-se a necessidade do preenchimento dos seguintes requisitos para a caracterização do acionista controlador: (i) ser titular de direitos de sócio que lhe assegurem, de forma permanente, a maioria dos votos nas deliberações da assembleia geral e o poder de eleger a maioria dos administradores da companhia; e (ii) usar efetivamente seu poder para dirigir as atividades sociais e orientar o funcionamento dos órgãos da companhia. $^{21}$

\footnotetext{
${ }^{19}$ BERLE, Adolf; MEANS, Gardiner. The Modern Corporation and Private Property. Revised Edition. First Edition 1932. New York: Harcourt, Brace \& World, Inc.,1967. p. 66-67.

20 "Art. 116. Entende-se por acionista controlador a pessoa, natural ou jurídica, ou o grupo de pessoas vinculadas por acordo de voto, ou sob controle comum, que: a) é titular de direitos de sócio que lhe assegurem, de modo permanente, a maioria dos votos nas deliberações da assembléia-geral e o poder de eleger a maioria dos administradores da companhia; e b) usa efetivamente seu poder para dirigir as atividades sociais e orientar o funcionamento dos órgãos da companhia. Parágrafo único. O acionista controlador deve usar o poder com o fim de fazer a companhia realizar o seu objeto e cumprir sua função social, e tem deveres e responsabilidades para com os demais acionistas da empresa, os que nela trabalham e para com a comunidade em que atua, cujos direitos e interesses deve lealmente respeitar e atender."

${ }^{21}$ EIZIRIK, Nelson. A Lei das S/A Comentada. Volume I. São Paulo: Quartier Latin, 2011. p. 665667.
} 
Essa definição foi dada em função da assembleia geral, uma vez que exige do acionista a titularidade de direitos de sócio que lhe assegurem maioria dos votos nas deliberações. E não basta apenas que o titular detenha a maioria das ações, como também as utilize de forma a exercer o poder de fato, em conformidade com o entendimento de LAMY FILHO e BULHÕES PEDREIRA de que "[o] poder de controle é poder de fato, e não poder jurídico". ${ }^{22}$

Sobre a utilização da maioria para o exercício do poder de fato, BORBA afirma o seguinte sobre a definição dada pelo artigo 116:

Trata-se de definição eminentemente centrada na realidade material, porquanto apenas considera controlador quem tem a maioria dos votos nas assembleias e, ao mesmo tempo, usa essa maioria para comandar a sociedade. Quem tem a maioria e não a utiliza é sócio majoritário, mas não é controlador. As maiorias eventuais também não caracterizam o controle, pois para tanto exige a lei um poder permanente. $^{23}$

Nessa linha, é interessante notar que, no âmbito do Novo Mercado, é possível verificar a existência ou não do poder de fato quando determinado acionista tenha assegurado maioria absoluta dos votos nas três últimas assembleias, conforme abaixo:

Há presunção relativa de titularidade do controle em relação à pessoa ou ao Grupo de Acionistas que seja titular de ações que lhe tenham assegurado a maioria absoluta dos votos dos acionistas presentes nas 3 (três) últimas assembleias gerais da Companhia, ainda que não seja titular das ações que the assegurem a maioria absoluta do capital votante. ${ }^{24}$

Para classificação do poder de controle, os autores BERLE e MEANS propuseram cinco espécies de controle interno: (i) controle quase

${ }^{22}$ LAMY FILHO, Alfredo; BULHÕES PEDREIRA, José Luiz. Estrutura da Companhia. In: LAMY FILHO, Alfredo; BULHÕES PEDREIRA, José Luiz (Coord.). Direito das Companhias. Volume I. Rio de Janeiro: Forense, 2009. p. 827.

${ }^{23}$ BORBA, José Edwaldo Tavares. Direito societário. 13ª ed. Rio de Janeiro: Renovar, 2012. p. 366.

${ }^{24}$ Conforme o Regulamento de Listagem do Novo Mercado da BM\&FBovespa, o poder de controle "significa o poder efetivamente utilizado de dirigir as atividades sociais e orientar o funcionamento dos órgãos da Companhia, de forma direta ou indireta, de fato ou de direito, independentemente da participação acionária detida. Há presunção relativa de titularidade do controle em relação à pessoa ou ao Grupo de Acionistas que seja titular de ações que lhe tenham assegurado a maioria absoluta dos votos dos acionistas presentes nas 3 (três) últimas assembleias gerais da Companhia, ainda que não seja titular das ações que lhe assegurem a maioria absoluta do capital votante". 
totalitário (control through almost complete ownership); (ii) controle majoritário (majority control); (iii) controle mediante expedientes legais (through a legal device) ${ }^{25}$; (iv) controle minoritário (minority control) e; (v) controle administrativo ou gerencial (management control). ${ }^{26}$ COMPARATO, no entanto, entende que a terceira espécie seria discutível, visto que a originalidade do instituto não permite a generalização dessa espécie particular de controle aos demais sistemas jurídicos. ${ }^{27}$ Sendo assim, adotar-se-á o modelo de classificação do controle interno sugerido por COMPARATO.

Além disso, analisar-se-á também a modalidade de controle externo, amplamente reconhecida pela doutrina, inclusive, pelos autores da Lei da S.A., LAMY FILHO e BULHÕES PEDREIRA. ${ }^{28}$

\section{2 - Controle interno}

Segundo LAMY FILHO e BULHÕES PEDREIRA, o controle interno é "próprio da estrutura da companhia". ${ }^{29}$

Para os fins deste trabalho, serão consideradas como espécies do controle interno: (i) o totalitário; (ii) o majoritário; (iii) o minoritário; e (iv) o gerencial.

\subsection{1 - Controle totalitário}

\footnotetext{
25 "In the effort to maintain control of a corporation without ownership of a majority of its stock, various legal devices have been developed. Of these, the most important among the very large companies is the device of 'pyramiding'. This involves the owning of a majority of the stock of one corporation which in turn holds a majority of the stock of another-a process which can be repeated a number of times" (BERLE, Adolf; MEANS, Gardiner. The Modern Corporation and Private Property. Harcourt, Brace \& World, Inc. New York. Revised Edition. 1967. First Edition 1932. p. 69).

26 "Five more types can be distinguished, though no sharp dividing line separates type from type. This include (1) control through almost complete ownership, (ii) majority control, (3) control through a legal device without majority ownership, (4) minority control, and (5) management control. Of these, the first three are forms of control resting on a legal base and revolve about the right to vote a majority of the voting stock. The last two, minority and management control are extra legal, resting on a factual rather than a legal base." (Ibid. p. 67).

${ }^{27}$ COMPARATO, Fábio Konder. O poder de controle na sociedade anônima. 6. ed. Rio de Janeiro: Ed. Forense, 2014. p. 54.

${ }^{28}$ LAMY FILHO, Alfredo; BULHÕES PEDREIRA, José Luiz. Estrutura da Companhia. In: LAMY FILHO, Alfredo; BULHÕES PEDREIRA, José Luiz (Coord.). Direito das Companhias. Volume I. Rio de Janeiro: Forense, 2009. p. 830-832.

${ }^{29}$ Ibid. p. 831.
} 
O controle totalitário consiste no poder exercido com quase a completa titularidade acionária, sendo similar à sociedade unipessoal. De acordo com COMPARATO, caracteriza-se:

[...] quando nenhum acionista é excluído do poder de dominação na sociedade, quer se trate de sociedade unipessoal, quer se esteja diante de uma companhia do tipo familiar (controle totalitário conjunto) ${ }^{30}$.

No entanto, como nota o autor, basta:

[...] que exista um só outro acionista, titular de uma única ação, ainda que sem direito a voto, para que se dissipe o caráter totalitário do controle e reapareça a possibilidade de conflitos de interesse entre sócios ${ }^{31}$.

A Lei das S.A. consagra o princípio majoritário no artigo $129^{32}$ quando exige que as deliberações da assembleia sejam aprovadas por maioria absoluta dos votos, ressalvados os votos em branco, e observadas exceções previstas.

Sendo assim, o titular desse controle seria, a princípio, capaz de aprovar todas as deliberações submetidas à assembleia geral, embora isso não seja possível, por exemplo, nos casos em que Lei das S.A. exige unanimidade para aprovação ${ }^{33}-34$.

\subsection{2 - Controle majoritário}

O conceito de controle majoritário pode ser extraído da própria Lei das S.A. quando reconhece como controlador aquele que é "titular de direitos de sócio que lhe assegurem, de modo permanente, a maioria dos votos nas deliberações da assembléia-geral".

Sobre isso, afirma VALVERDE:

A assembléia geral dos acionistas, como órgão da pessoa jurídica, recebe a energia volitiva dos membros que a compõem, mas só filtra a corrente mais forte,

\footnotetext{
${ }^{30}$ COMPARATO, Fábio Konder. O poder de controle na sociedade anônima. 6. ed. Rio de Janeiro: Ed. Forense, 2014. p. 50.

${ }^{31}$ Ibid. p. 45.

32 “Art. 129. As deliberações da assembléia-geral, ressalvadas as exceções previstas em lei, serão tomadas por maioria absoluta de votos, não se computando os votos em branco. [...]".

${ }^{33}$ Art. 87, § $2^{\circ}$; art. 221; art. 229, § 5% e o art. 294, § $2^{\circ}$ da Lei 6.404/76.

34 NASCIMENTO, João Pedro Barroso do. Medidas Defensivas à Tomada de Controle de Companhias. São Paulo: Quartier Latin, 2011. p. 40.
} 
manifestada pela voz da maioria, corrente que movimentará o corpo social, através de seu órgão de direção. ${ }^{35}$

Sobre o caráter majoritário dessa espécie de controle, é interessante a questão levantada por COMPARATO:

[...] Mas por que a maioria deve comandar? Parte-se, sem dúvida, do postulado de que a sociedade existe no interesse dos sócios, e como ninguém, em princípio, está investido da prerrogativa de decidir pelos interesses alheios, prevalece sempre a vontade do maior número, julgando cada qual segundo o seu próprio interesse. $^{36}$

\section{Em resposta a essa mesma pergunta, LAMY FILHO e BULHÕES}

PEDREIRA entendem que o papel do controlador em uma companhia é extremamente importante, tendo em vista que:

[...] a presença do acionista controlador é fundamental na criação, no desenvolvimento e para a continuidade da empresa porque é ele quem assegura estabilidade administrativa, sem a qual nenhuma empresa prospera e sobrevive ${ }^{37}$.

\section{Sobre isso afirma VALVERDE:}

O egoísmo ou a incompreensão de alguns acionistas não havia de prevalecer contra o interêsse coletivo e da organização econômica da nação, em que a sociedade anônima tem sede e desenvolve a sua atividade. Para que, pois, a emprêsa continue, não cesse o seu trabalho e possa adaptar-se às novas concepções ou imposições do tempo que atravessa, era necessário que a lei garantisse à maioria dos que dirigem a corporação e representam o interêsse preponderante o direito de alterar ou reformar as regras, que disciplinam o funcionamento da pessoa jurídica e regulam os direitos e obrigações dos seus membros..$^{38}$

Percebe-se que o controle majoritário constitui a modalidade de controle mais usual no país, devido à alta concentração acionária verificada no mercado brasileiro.

É possível definir o controle majoritário, de forma ainda mais clara, como aquele que se caracteriza quando um acionista e/ou grupo de

\footnotetext{
${ }^{35}$ VALVERDE, Trajano de Miranda. Sociedades por Ações. Vol. II. $3^{\text {a }}$ edição. 1959. Rio de Janeiro: Forense. p. 114.

36 COMPARATO, Fábio Konder. O poder de controle na sociedade anônima. 6. ed. Rio de Janeiro: Ed. Forense, 2014. p. 50-51.

${ }^{37}$ LAMY FILHO, Alfredo; BULHÕES PEDREIRA, José Luiz. Estrutura da Companhia. In: LAMY FILHO, Alfredo; BULHÕES PEDREIRA, José Luiz (Coord.). Direito das Companhias. Volume I. Rio de Janeiro: Forense, 2009. p. 814.

38 VALVERDE, Trajano de Miranda. Sociedades por Ações. Vol. II. $3^{a}$ edição. 1959. Rio de Janeiro. Forense. Pág. 151-152.
} 
acionistas detém, em conjunto ou isoladamente, a maioria das ações com direito a voto. ${ }^{39}$

Como ensina EIZIRIK, nas companhias com controle majoritário, "muitas vezes, nota-se uma sobreposição entre a propriedade das ações que assegurem o poder de controle e as funções executivas, particularmente aquelas atribuídas ao conselho de administração" 40 . Ou seja, neste caso, quem de fato controla a companhia são seus proprietários e não seus administradores, ao contrário do que ocorre no controle gerencial, modelo predominantemente adotado nos Estados Unidos.

Faz-se necessário destacar que também é bastante comum na prática brasileira que o controle majoritário seja estabelecido por meio de acordo de acionistas, nos termos do artigo $118^{41}$ da Lei das S.A., entre acionistas

39 NASCIMENTO, João Pedro Barroso do. Medidas Defensivas à Tomada de Controle de Companhias. São Paulo: Quartier Latin, 2011. p. 41.

${ }^{40}$ EIZIRIK, Nelson; GAAL, Ariádna B.; PARENTE, Flávia; HENRIQUES, Marcus Freitas. Mercado de Capitais - Regime Jurídico. 3ed. Rio de Janeiro: Renovar, 2011. p. 394.

41 “Art. 118. Os acordos de acionistas, sobre a compra e venda de suas ações, preferência para adquiri-las, exercício do direito a voto, ou do poder de controle deverão ser observados pela companhia quando arquivados na sua sede.(Redação dada pela Lei $n^{\circ} 10.303$, de 2001 ) $\S 1^{\circ}$ As obrigações ou ônus decorrentes desses acordos somente serão oponíveis a terceiros, depois de averbados nos livros de registro e nos certificados das ações, se emitidos. $\S 2^{\circ}$ Esses acordos não poderão ser invocados para eximir o acionista de responsabilidade no exercício do direito de voto (artigo 115) ou do poder de controle (artigos 116 e 117). $\S 3^{\circ}$ Nas condições previstas no acordo, os acionistas podem promover a execução específica das obrigações assumidas. $\S 4^{\circ}$ As ações averbadas nos termos deste artigo não poderão ser negociadas em bolsa ou no mercado de balcão. $\S 5^{\circ}$ No relatório anual, os órgãos da administração da companhia aberta informarão à assembléiageral as disposições sobre política de reinvestimento de lucros e distribuição de dividendos, constantes de acordos de acionistas arquivados na companhia. $\S 6^{\circ} \mathrm{O}$ acordo de acionistas cujo prazo for fixado em função de termo ou condição resolutiva somente pode ser denunciado segundo suas estipulações. (Incluído pela Lei $n^{\circ} 10.303$, de 2001) $\S 7^{\circ} \mathrm{O}$ mandato outorgado nos termos de acordo de acionistas para proferir, em assembléia-geral ou especial, voto contra ou a favor de determinada deliberação, poderá prever prazo superior ao constante do $\S 1^{\circ}$ do art. 126 desta Lei.(Incluído pela Lei $n^{\circ} 10.303$, de 2001) $\S 8^{\circ}$ O presidente da assembléia ou do órgão colegiado de deliberação da companhia não computará o voto proferido com infração de acordo de acionistas devidamente arquivado.(Incluído pela Lei $\mathrm{n}^{\circ} 10.303$, de 2001) $\S 9^{\circ} \mathrm{O}$ não comparecimento à assembléia ou às reuniões dos órgãos de administração da companhia, bem como as abstenções de voto de qualquer parte de acordo de acionistas ou de membros do conselho de administração eleitos nos termos de acordo de acionistas, assegura à parte prejudicada o direito de votar com as ações pertencentes ao acionista ausente ou omisso e, no caso de membro do conselho de administração, pelo conselheiro eleito com os votos da parte prejudicada. (Incluído pela Lei $\mathrm{n}^{\circ}$ 10.303, de 2001) § 10. Os acionistas vinculados a acordo de acionistas deverão indicar, no ato de arquivamento, representante para comunicar-se com a companhia, para prestar ou receber informações, quando solicitadas.(Incluído pela Lei $n^{\circ} 10.303$, de 2001) § 11. A companhia poderá solicitar aos membros do acordo esclarecimento sobre suas cláusulas. (Incluído pela Lei $\mathrm{n}^{\circ}$ 10.303, de 2001)" 
que em conjunto exerçam o controle de forma compartilhada, constituindo um bloco de controle.

Sobre isso afirma MUNIZ:

O objetivo do acordo de voto é obrigar um certo número de acionistas a harmonizar o exercício de voto em bloco, como se fosse um único acionista, pelo menos no que tange às matérias cuja uniformização de voto foram acordadas. No Brasil, na sua grande maioria, tem por objeto constituir uma maioria acionária sustentável. ${ }^{42}$

\subsection{3 - Controle minoritário}

Segundo definição proposta por EIZIRIK, o controle minoritário:

[...] caracteriza-se quando, dada a dispersão das ações da companhia no mercado, um acionista ou grupo de acionistas exerce o poder de controle com menos da metade do capital votante, uma vez que nenhum outro acionista ou grupo está organizado ou detém maior volume de ações com direito a voto." 43

COMPARATO, de forma ainda mais concisa, define o controle minoritário como o controle fundado em número de ações inferior à metade do capital votante, o que os autores norte-americanos denominam working control. ${ }^{44}$

Ressalte-se que o detentor dessa espécie de controle pode encontrar dificuldades para aprovar determinadas matérias para as quais a Lei das S.A. exige quórum específico de aprovação. Um exemplo é o quórum de maioria do capital com direito a voto para a aprovação das matérias elencadas no artigo $136 .{ }^{45}$

\footnotetext{
${ }^{42}$ MUNIZ, Ian de Porto Alegre. Fusões e Aquisições - Aspectos Fiscais e Societários. $2^{\mathrm{a}}$ edição. São Paulo: Quartier Latin, 2011. p. 340.

${ }^{43}$ EIZIRIK, Nelson. A Lei das S/A Comentada. Volume I. São Paulo: Quartier Latin, 2011. p. 671.

${ }^{44}$ COMPARATO, Fábio Konder. O poder de controle na sociedade anônima. 6 . ed. Rio de Janeiro: Ed. Forense, 2014. p. 54.

45 “Art. 136. É necessária a aprovação de acionistas que representem metade, no mínimo, das ações com direito a voto, se maior quorum não for exigido pelo estatuto da companhia cujas ações não estejam admitidas à negociação em bolsa ou no mercado de balcão, para deliberação sobre: I criação de ações preferenciais ou aumento de classe de ações preferenciais existentes, sem guardar proporção com as demais classes de ações preferenciais, salvo se já previstos ou autorizados pelo estatuto; II - alteração nas preferências, vantagens e condições de resgate ou amortização de uma ou mais classes de ações preferenciais, ou criação de nova classe mais favorecida; III - redução do dividendo obrigatório; IV - fusão da companhia, ou sua incorporação em outra; V - participação em grupo de sociedades (art. 265); VI - mudança do objeto da companhia; VII - cessação do estado de liquidação da companhia; VIII - criação de partes beneficiárias; IX - cisão da companhia; X - dissolução da companhia. (Incluído pela Lei $n^{\circ} 9.457$, de 1997) § $1^{\circ}$ Nos casos dos incisos I e II, a eficácia da deliberação depende de prévia aprovação ou da ratificação, em prazo
} 
A Lei das S.A., no entanto, reconheceu implicitamente a possibilidade de um controle minoritário, tendo em vista que a norma geral é a de que a assembleia geral se instala, em primeira convocação, com a presença de acionistas que representem no mínimo um quarto do capital social com direito a voto.

\subsection{4 - Controle gerencial}

Conforme COMPARATO, o controle administrativo ou gerencial caracteriza-se como aquele que é fundado não na participação acionária, mas unicamente nas prerrogativas diretoriais. ${ }^{46}$ Ou seja, esse controle para ser exercido não pressupõe a titularidade de ações em que se divide o capital.

Isso ocorre nos casos em que, dada a extrema dispersão acionária das ações e do absenteísmo de acionistas com participações relevantes, os administradores passam a assumir o poder de controle. Ocorre assim a chamada autoperpetuação dos administradores da companhia, que é empreendida por meio da proxy machinery, assim amplamente citada pela doutrina brasileira, que consiste em pedidos públicos de procuração realizados pelos administradores aos acionistas da companhia. ${ }^{47}$

Ressalte-se que a possibilidade de realização de pedidos públicos de procuração vem da experiência norte-americana. O pedido de procuração, que deve ser dirigido a todos os acionistas cujos endereços constem dos

\footnotetext{
improrrogável de um ano, por titulares de mais da metade de cada classe de ações preferenciais prejudicadas, reunidos em assembléia especial convocada pelos administradores e instalada com as formalidades desta Lei. $\S 2^{\circ}$ A Comissão de Valores Mobiliários pode autorizar a redução do quorum previsto neste artigo no caso de companhia aberta com a propriedade das ações dispersa no mercado, e cujas 3 (três) últimas assembléias tenham sido realizadas com a presença de acionistas representando menos da metade das ações com direito a voto. Neste caso, a autorização da Comissão de Valores Mobiliários será mencionada nos avisos de convocação e a deliberação com quorum reduzido somente poderá ser adotada em terceira convocação. $\S 3$ o O disposto no $\S$ 2o deste artigo aplica-se também às assembléias especiais de acionistas preferenciais de que trata o $\S 10$. (Redação dada pela Lei $n^{\circ} 10.303$, de 2001) $\S 4^{\circ}$ Deverá constar da ata da assembléia-geral que deliberar sobre as matérias dos incisos I e II, se não houver prévia aprovação, que a deliberação só terá eficácia após a sua ratificação pela assembléia especial prevista no $\S 1^{\circ}$. (Incluído pela Lei no 9.457, de 1997)"

${ }^{46}$ COMPARATO, Fábio Konder. O poder de controle na sociedade anônima. 6. ed. Rio de Janeiro: Ed. Forense, 2014. p. 60.

47 NASCIMENTO, João Pedro Barroso do. Medidas Defensivas à Tomada de Controle de Companhias. São Paulo: Quartier Latin, 2011. p. 43.
} 
registros da companhia, pode ser feito por pessoa que deseje angariar votos para deliberações em companhias que não possuem acionista majoritário definido e que precisam mobilizar votos para aprovação de matérias. ${ }^{48}$

A Instrução CVM 481 de dezembro de 2009 dispõe sobre informações, pedidos públicos de procuração, participação e votação a distância em assembleias de acionistas.

Para a referida instrução, são considerados pedidos públicos de procuração: (i) os pedidos que empreguem meios públicos de comunicação, tais como a televisão, o rádio, revistas jornais e páginas na rede mundial de computadores; (ii) os pedidos dirigidos a mais de cinco acionistas, quando promovidos, direta ou indiretamente, pela administração ou por acionista controlador; e (iii) os pedidos dirigidos a mais de dez acionistas, quando promovidos por qualquer outra pessoa.

A adoção dos pedidos, ao passo em que permite o fácil atendimento dos quóruns de instalação pela outorga de direitos de representação, não deve acarretar a massiva presença de acionistas nas assembleias, posto que os votos são outorgados a poucas pessoas, notadamente os administradores. ${ }^{49}$

A matéria tratada na Instrução 481/09 pode ainda não ter reconhecida sua devida importância na experiência brasileira, mas se tornará um dos pilares do funcionamento das companhias brasileiras caso a tendência de pulverização do capital se concretize. Neste cenário, deverão tomar lugar as proxy contests ou proxy fights, brigas por procurações para exercício do controle de companhias, o que contribuirá para a afirmação do controle gerencial no Brasil.

Sobre as proxy fights, nota COMPARATO:

[...] como o controle minoritário e, sobretudo, o administrativo é instável, não se pode excluir a possibilidade de que os candidatos à tomada do poder procurem ter

\footnotetext{
48 APPENDINO, Fábio. O Instituto do Direito de Voto em um Contexto de Dispersão Acionária. In: CASTRO, Rodrigo R. Monteiro de; MOURA AZEVEDO, Luís André N. de (Coord.). Poder de Controle e Outros Temas de Direito Societário e Mercado de Capitais. São Paulo: Quartier Latin. p. 453.

${ }^{49}$ Ibid. p. 455.
} 
acesso ao mesmo eleitorado. Daí o surgimento de disputas ásperas, nas quais a caça às procurações implica o dispêndio de somas consideráveis. É óbvio que, nessas proxy fights, o detentor do poder de controle leva sobre o outsider insurgente a grande vantagem de poder contar com os recursos da própria companhia, com a sua organização interna (notadamente os registros de acionistas) e com o prestígio que confere todo o poder instalado contra as "manobras subversivas". Mas a regra também comporta exceções. Em todo caso, o magnata Rockefeller foi obrigado a despender oitocentos mil dólares em 1929 (que, ressalte-se, não são oitocentos mil dólares atuais) para conseguir a destituição da diretoria da Standard Oil of Indiana, na qual possuía 14,5 das ações. ${ }^{50}{ }_{-}^{51}$

${ }^{50}$ COMPARATO, Fábio Konder. O poder de controle na sociedade anônima. 6. ed. Rio de Janeiro: Ed. Forense, 2014. p. 196-197.

${ }^{51}$ BERLE e MEANS descrevem o evento da seguinte forma: "In recent years the most striking illustration of this fight for control was presented by the open warfare between Mr. John D. Rockefeller, Jr., and the management of the Standard Oil Company of Indiana. Mr. Rockefeller actually held 14.9 per cent of the voting stock. He had been in substantial control of the company for years. Colonel Stewart, the chairman of the board of directors and undeniably the driving force behind much of that company's activity, displeased Mr. Rockfeller in connection with certain transactions which were the subject of discussion during the administration of President Harding. He asked Colonel Stewart to resign; Stewart refused and did not grant to Mr. Rockefeller the use of the proxy machinery at the following annual election of directors. Thereupon Mr. Rockefeller waged a most dramatic proxy battle against him. He circularized the stockholders at considerable expense, asking for proxies. He engaged the most eminent legal talent to guard against any 'technical mistakes'. He brought to bear the tremendous influence of his standing in the community. The Wall Street Journal pointed out at the time that the fight marked the first time the Rockefeller domination in a large Standard Oil unit 'had been really in question'. In opposition, Colonel Stewart obtained the full support of the existing board of directors and sought the support of the 16,000 employees who were stockholders. At this most opportune moment the company declared a 50 per cent stock dividend. The issue was for long in grave doubt. Four days previous to the election both sides are reported to have claimed the support of a majority, the one of votes and the other of stockholders. In the final election of directors, Mr. Rockefeller won, 59 per cent of the votes outstanding or 65 per cent of the votes cast being in favor of his candidates. Control may be said to have remained in his hands. Colonel Stewart's connection with the company was brought to a close.

The basis for Mr. Rockefeller's success in this fight must be a matter of conjecture, but, though his ownership of the stock formed the nucleus about which he attracted support, the outcome did not rest on ownership alone. He appears to have won partly because the public in general sided with him in his view of the transaction to which Stewart had been a party, and still more, perhaps, because Mr. Rockefeller's own standing in the community commanded the confidence of a large body of stockholders. The difficulty and cost of dislodging the management, however, emphasizes the precarious nature of control resting on the ownership of a minority of the voting stock, - a control which would appear in ordinary times to be adequately safeguarded, - and further emphasizes the importance of the management to any effective minority control.

This case has been described in detail because it probably marks the dividing line between minority control and management control. If Mr. Stewart had won the fight we could say that management without appreciable ownership was in the saddle. As it is, we may say that Mr. Rockefeller is in control, to a considerable degree through his ownership of a minority interest of 14.9 per cent and in part through less tangible factors. Could other men with less prestige and financial power have retained control with but a 15 per cent ownership? Could Mr. Rockefeller have retained control if his ownership had been appreciably less? Here would seem to be control based on the minimum of ownership which would allow it to be held separate from the titular management." (BERLE, Adolf; MEANS, Gardiner. The Modern Corporation and Private Property. Harcourt, Brace \& World, Inc. New York. Revised Edition. 1967. First Edition 1932. p. 76-78.) 
De todo modo, nota-se que é esse ambiente de dispersão que propicia a tomada de controle hostil, tendo em vista a acentuada pulverização das ações. Conforme observa NASCIMENTO:

A existência da dispersão acionária é premissa essencial para a tomada de controle. A aquisição de controle em companhia com concentração acionária pressupõe a concordância entre o titular do poder de controle em aliená-lo ao adquirente, o que, por si só, inviabiliza a ideia da tomada de controle, que é entendida como operação realizada à revelia de acionistas relevantes e/ou administradores. ${ }^{52}$

Portanto, para os fins deste trabalho, o controle gerencial, assim como o minoritário, será associado ao gênero do controle difuso, em que não há acionista detentor de ações que represente mais da metade do capital social. As companhias de controle difuso são as que estão mais suscetíveis às tentativas de tomada de controle.

\section{3 - Controle externo}

O controle externo, nas palavras de LAMY FILHO e BULHÕES PEDREIRA, é a "modalidade de influência dominante sobre a companhia com fundamento em contratos desta com terceiros ou de poder cuja fonte são as relações de participação nos mercados." 53

Sendo assim, o controle externo pode ser exercido, por exemplo, por uma empresa que possua direitos de crédito contra outra qualquer. Conforme nota COMPARATO:

Há, assim, em primeiro lugar, toda uma série de hipóteses em que o controle externo resulta de uma situação de endividamento da sociedade. Em razão do seu direito de crédito, cuja execução forçada pode levar a companhia à falência, o credor passa, muitas vezes, a dominar a devedora, comandando a sua exploração empresarial. ${ }^{54}$

\footnotetext{
52 NASCIMENTO, João Pedro Barroso do. Medidas Defensivas à Tomada de Controle de Companhias. São Paulo: Quartier Latin, 2011. p. 47.

${ }^{53}$ LAMY FILHO, Alfredo; BULHÕES PEDREIRA, José Luiz. Estrutura da Companhia. In: LAMY FILHO, Alfredo; BULHÕES PEDREIRA, José Luiz (Coord.). Direito das Companhias. Volume I. Rio de Janeiro: Forense, 2009. p. 830-832.

${ }^{54}$ COMPARATO, Fábio Konder. O poder de controle na sociedade anônima. 6. ed. Rio de Janeiro: Ed. Forense, 2014. p. 78.
} 
A Lei das S.A., por sua vez, trata apenas da modalidade de controle interno, e não de controle externo ${ }^{55}$, embora este seja verificado na prática.

${ }^{55}$ LAMY FILHO, Alfredo; BULHÕES PEDREIRA, José Luiz. Estrutura da Companhia. In: LAMY FILHO, Alfredo; BULHÕES PEDREIRA, José Luiz (Coord.). Direito das Companhias. Volume I. Rio de Janeiro: Forense, 2009. p. 832. 


\section{CAPÍTULO 2 - A OFERTA PÚBLICA DE AQUISIÇÃo DE CONTROLE}

\section{1 - Conceito}

\section{Conforme NASCIMENTO:}

A oferta para aquisição de controle é realizada por ofertante interessado em adquirir ações de certa companhia aberta (companhia-alvo) diretamente de seus acionistas, mediante a realização de uma oferta pública, com o objetivo de adquirir e/ou consolidar o poder de controle. ${ }^{56}$

\section{Na definição de SILVEIRA LOBO:}

A oferta pública para aquisição de controle de companhia aberta é uma proposta irrevogável de contratar a compra e venda ou a permuta de ações com direito a voto de uma companhia aberta, em quantidade suficiente para assegurar ao adquirente o controle da companhia, dirigida indistintamente a todos os titulares dessas ações por meio da publicação em jornal de grande circulação. ${ }^{57}$

Sendo assim, tal oferta constitui uma declaração de vontade unilateral por meio da qual o proponente manifesta, por determinado prazo, o compromisso de adquirir uma quantidade de ações a um certo preço e segundo cláusulas e condições previamente estabelecidas. ${ }^{58}$

\section{2 - Classificação}

Conforme classificação proposta por NASCIMENTO, a oferta pública de aquisição de controle é uma modalidade de aquisição de controle voluntária, originária, decorrente de operação isolada, e pode ser amigável ou hostil, conforme o caso. É voluntária, pois se caracteriza pela manifestação volitiva do adquirente, diferentemente da aquisição involuntária, que se dá por motivos externos a sua vontade. ${ }^{59}$

Conforme o autor observa, considera-se originária, pois o bloco de ações que representa o controle se forma inicial e originalmente a partir da

\footnotetext{
56 NASCIMENTO, João Pedro Barroso do. Medidas Defensivas à Tomada de Controle de Companhias. São Paulo: Quartier Latin, 2011. p. 75.

57 SILVEIRA LOBO, Carlos Augusto da. Oferta Pública para Aquisição de Controle de Companhia Aberta. In: LAMY FILHO, Alfredo; BULHÕES PEDREIRA, José Luiz. Direito das Companhias. Volume II. Rio de Janeiro: Forense, 2009. p. 2031-2032.

${ }^{58}$ EIZIRIK, Nelson. A Lei das S/A Comentada. Volume III. São Paulo: Quartier Latin, 2011. p. 456.

59 NASCIMENTO, João Pedro Barroso do. Medidas Defensivas à Tomada de Controle de Companhias. São Paulo: Quartier Latin, 2011. p. 57.
} 
reunião, pelo ofertante, das ações que se encontravam dispersas no mercado, diferentemente da derivada. Nas aquisições derivadas, o adquirente compra ações da companhia nas condições em que se encontravam no patrimônio do alienante. ${ }^{60}$

Em outras palavras, a aquisição originária se dá não com a transferência do bloco de controle, mas sim com a formação do bloco de controle pelo adquirente. Ressalte-se que, no regime jurídico brasileiro, a distinção entre aquisições de controle sob a forma originária ou derivada é importante para determinar a aplicação do artigo $254-\mathrm{A}^{61}$ da Lei das S.A. que se aplica às aquisições derivadas.

As aquisições derivadas pressupõem a existência de um bloco de controle já constituído na companhia-alvo, a ser adquirido, nas condições em que se encontra, pelo adquirente. Faz-se necessário, portanto, analisar caso a caso se houve ou não transferência de controle, de maneira a determinar a incidência de realização de oferta pública de aquisição de ações pertencentes aos acionistas minoritários, conforme o disposto no artigo 254-A, o que não ocorre nas aquisições de controle originárias. ${ }^{62}$

Considera-se decorrente de operação isolada, visto que a oferta pública tende a adquirir o poder de controle em uma única operação, e não

\footnotetext{
${ }^{60}$ Ibid. p. 75.

${ }^{61}$ Art. 254-A. A alienação, direta ou indireta, do controle de companhia aberta somente poderá ser contratada sob a condição, suspensiva ou resolutiva, de que o adquirente se obrigue a fazer oferta pública de aquisição das ações com direito a voto de propriedade dos demais acionistas da companhia, de modo a lhes assegurar o preço no mínimo igual a $80 \%$ (oitenta por cento) do valor pago por ação com direito a voto, integrante do bloco de controle. $\S 1^{\circ}$ Entende-se como alienação de controle a transferência, de forma direta ou indireta, de ações integrantes do bloco de controle, de ações vinculadas a acordos de acionistas e de valores mobiliários conversíveis em ações com direito a voto, cessão de direitos de subscrição de ações e de outros títulos ou direitos relativos a valores mobiliários conversíveis em ações que venham a resultar na alienação de controle acionário da sociedade. $\S 2^{\circ}$ A Comissão de Valores Mobiliários autorizará a alienação de controle de que trata o caput, desde que verificado que as condições da oferta pública atendem aos requisitos legais. $\S 3^{\circ}$ Compete à Comissão de Valores Mobiliários estabelecer normas a serem observadas na oferta pública de que trata o caput. $\S 4^{\circ} \mathrm{O}$ adquirente do controle acionário de companhia aberta poderá oferecer aos acionistas minoritários a opção de permanecer na companhia, mediante o pagamento de um prêmio equivalente à diferença entre o valor de mercado das ações e o valor pago por ação integrante do bloco de controle.

62 NASCIMENTO, João Pedro Barroso do. Medidas Defensivas à Tomada de Controle de Companhias. São Paulo: Quartier Latin, 2011. p. 60.
} 
por meio de operações conjuntas, como por exemplo, mediante operações de compra em bolsa de valores. ${ }^{63}$

Por fim, as ofertas públicas podem ser amigáveis ou hostis. Deve-se analisar no caso se a oferta foi realizada ou não com consentimento dos administradores e/ou dos acionistas relevantes da companhia. Se a aquisição foi realizada com esse consentimento, será considerada amigável. Já se foi realizada sem esse consentimento, será considerada hostil. ${ }^{64}$

No mercado norte-americano são reconhecidos como raiders ${ }^{65}$ aqueles que têm por objetivo adquirir o controle de companhias de maneira hostil. Toma-se como exemplo o personagem Edward Lewis protagonizado pelo ator Richard Gere em "Pretty Woman” (1990) ${ }^{66}$, um executivo que, com o suporte de seu advogado, vive uma vida multimilionária através da aquisição hostil de empresas que passam por grandes dificuldades financeiras, buscando auferir lucros imediatos, com a alienação de seus ativos. Assim como em “Other People's Money" (1991) ${ }^{67}$, filme em que o personagem principal exerce atividade similar no mercado, e passa a ser conhecido por todos como "Larry the liquidator".

Nota-se, pelo exemplo do cinema norte-americano, como a terminologia hostile raiders pode acabar por tomar, algumas vezes, uma conotação negativa, como se os ofertantes interessados em adquirir o controle de companhia aberta de forma hostil estivessem apenas interessados em saqueá-la, tomando seus bens e ativos. ${ }^{68}$

As ofertas públicas de aquisição se revelaram como instrumentos eficientes para a aquisição hostil de companhias. Essas ofertas pressupõem

\footnotetext{
${ }^{63}$ Ibid. p. 75.

${ }^{64}$ Ibid. p. 61 .

65 “Corporate raider. pessoa ou sociedade que tenta tomar o controle de outra sociedade, contra sua vontade, por meio da compra de seu controle acionário e nomeação de nova diretoria." (CASTRO, Marcílio Moreira de. Dicionário de direito, economia e contabilidade: português-inglês/inglêsportuguês. 4. ed. Rio de Janeiro: Forense, 2013. p. 496).

${ }^{66}$ PRETTY WOMAN. Direção de Garry Marshall. Estados Unidos: Touchstone Pictures. 1990. A versão brasileira foi intitulada "Uma linda mulher".

67 OTHER PEOPLE'S MONEY. Direção de Norman Jewison. Estados Unidos: Warner Bros. 1991. A versão brasileira foi intitulada "Com o dinheiro dos outros".
} 
um elevado grau de dispersão das ações de emissão da companhia-alvo e a inexistência de poder de controle definido. ${ }^{69}$

Conforme já abordado no capítulo anterior, as companhias mais suscetíveis a uma eventual tomada hostil de controle são aquelas que possuem controle minoritário ou gerencial.

Conforme nota NASCIMENTO, essas ofertas de aquisição se destinam a todos os titulares de ações com direito a voto, em tratamento igualitário, de acordo com o princípio da generalidade da oferta (all holders rule). Por isso, é importante notar que a eventual hostilidade de uma oferta se dá em relação à administração e/ou acionistas relevantes, mas não em relação à companhia em si ou à generalidade dos acionistas, uma vez que há para estes a oportunidade de receber um valor maior por suas ações e negociar a venda das mesmas. ${ }^{70}$

Percebe-se que, por questões econômicas, e para convencer os acionistas a aderirem a oferta, o preço a ser ofertado é superior ao valor de cotação das ações em bolsa. E, por isso, muitos reconhecem que essas ofertas podem ser benéficas, do ponto de vista financeiro, para os acionistas da companhia-alvo. ${ }^{71}$

Além disso, é interessante destacar que existem as ofertas públicas para a aquisição de controle que são realizadas com recursos próprios, ou seja, o ofertante suporta todos os custos e despesas da tomada de controle com seus próprios recursos. E ainda, existem as ofertas públicas que são realizadas com recursos de terceiros, ou seja, o ofertante, nesse caso é financiado por terceiros. ${ }^{72}$

${ }^{68}$ NASCIMENTO, João Pedro Barroso do. Medidas Defensivas à Tomada de Controle de Companhias. São Paulo: Quartier Latin, 2011. p. 75.

${ }^{69}$ Ibid. p. 76.

${ }^{70}$ Ibid. p. $76-78$.

${ }^{71}$ Ibid. p. 78-79.

${ }^{72}$ Ibid. p. 100-101. 
Dentro dessa última modalidade, há o leveraged buyout ("LBO") ${ }^{73}$ ${ }^{74}$. Nessa operação de aquisição de controle, uma parcela substancial dos recursos utilizados para o pagamento das ações adquiridas é financiada por dívida assumida pelo ofertante. Usualmente, os terceiros que financiam são instituições financeiras que visam com o empréstimo participarem de eventuais ganhos posteriores, em caso de sucesso na obtenção do controle da companha-alvo. ${ }^{75}$

Faz-se necessário destacar também o management buy-out ("MBO") 76 . Note-se que os LBOs clássicos são gênero do qual os MBOs são espécie. A distinção básica é o fato de que os MBOs são LBOs em que o ofertante é membro da administração da companhia-alvo. ${ }^{77}$

A técnica do LBO visa viabilizar financeiramente a aquisição de controle e tem como característica "a transferência dos custos e despesas de aquisição para a sociedade adquirida, mediante a assunção por esta de uma dívida contraída para a sua aquisição." ${ }^{\text {78 }}$

Essas operações são estruturadas de forma a assegurar que o desembolso realizado pelo ofertante será recompensado quando da efetiva obtenção do controle da companhia-alvo. ${ }^{79}$

Pretende-se, nesses casos, transferir os custos e despesas para a companhia-alvo, de modo que o pagamento do endividamento realizado

\footnotetext{
${ }^{73}$ Segundo o Black's Law Dictionary, buyout significa "The purchase of all or a controlling percentage of the assets or shares of a business".

${ }^{74}$ Segundo o Black's Law Dictionary, leveraged buyout significa "The purchase of a publicly held corporation's outstanding stock by its management or outside investors, financed manly with funds borrowed from investment bankers or brokers and usu. secured by the corporation's assets". (GARNER, Bryan A. Black's Law Dictionary. 3a edição. Thomson/West, 2006. p. 84).

${ }^{75}$ NASCIMENTO, João Pedro Barroso do. Medidas Defensivas à Tomada de Controle de Companhias. São Paulo: Quartier Latin, 2011. p. 101.

${ }^{76}$ Segundo o Black's Law Dictionary, management buyout significa "1. A buyout of a corporation by its own directors and officers. 2. A leveraged buyout of a corporation by an outside entity in which the corporation's management has a material financial interest". (GARNER, Bryan A. Black's Law Dictionary. 3a edição. Thomson/West, 2006. p. 84).

${ }^{77}$ NASCIMENTO, João Pedro Barroso do. Medidas Defensivas à Tomada de Controle de Companhias. São Paulo: Quartier Latin, 2011. p. 101.

${ }^{78}$ OSÓRIO, José Diogo Horta. Da Tomada do Controlo de Sociedades (takeovers) por Leveraged Buy-Out e sua Harmonização com o Direito Português. Coimbra: Almedina, 2001. p. 9. Apud: NASCIMENTO, João Pedro Barroso do. Medidas Defensivas à Tomada de Controle de Companhias. São Paulo: Quartier Latin, 2011. p. 102.
} 
pelo ofertante seja realizado com os recursos da própria companhia-alvo recém adquirida. ${ }^{80}$

Utilizam-se, em casos típicos, uma sociedade-veículo, que não possua ativos ou passivos com valores significativos, para realizar a oferta pública para a aquisição de controle da companhia-alvo. A sociedadeveículo assume o endividamento em montante correspondente aos custos e despesas a serem suportados com a oferta. ${ }^{81}$

A sociedade-veículo, após adquirir o controle da companhia-alvo, é incorporada por esta. Sendo assim, todo o endividamento assumido é transferido à companhia-alvo que sucede a sociedade-veículo incorporada em bens e obrigações. ${ }^{82}$

\section{3 - Histórico}

Conforme exposto por NASCIMENTO, as tender offers se desenvolveram e receberam destaque nos Estados Unidos, sobretudo na década de 1980, conhecida como "deal decade". ${ }^{83}$

Nos EUA, até a década de 1960, o método comumente utilizado em operações hostis era o das batalhas por procurações para representação em assembleia, conhecidas pela doutrina norte-americana como proxy fights. A partir da década de 1960, surgiram novos métodos, como o da "Saturday Night Special" ${ }^{84}$

Em relação a este último método, conforme destaca o autor, as ofertas hostis de aquisição de controle se realizavam, basicamente, às sextas-feiras, por valores superiores aos da cotação em bolsa, de modo a convencer os investidores a aceitar a oferta no início da semana seguinte. Os pagamentos seriam realizados em dinheiro, à vista, na ordem em que os acionistas da companhia-alvo aceitassem a oferta. Além disso, a oferta

\footnotetext{
79 NASCIMENTO, João Pedro Barroso do. Medidas Defensivas à Tomada de Controle de Companhias. São Paulo: Quartier Latin, 2011. p. 102.

${ }^{80}$ Ibid. p. 102.

${ }^{81}$ Ibid. p. 102.

${ }^{82}$ Ibid. p. 102.

${ }^{83}$ Ibid. p. 79.

${ }^{84}$ Ibid. p. 81.
} 
estaria limitada a determinado percentual do capital social da companhiaalvo, suficiente apenas para assegurar o controle..$^{85}$

A oferta permanecia aberta apenas durante o final de semana, com previsão de adesão no início da semana subsequente. Os acionistas que demorassem a aderir ou que não aderissem à oferta não teriam suas ações adquiridas pelo ofertante. Em alguns casos, esses acionistas ficavam "congelados" na companhia-alvo e sem liquidez para vender suas ações no mercado. ${ }^{86}$

Logo após o ofertante adquirir o controle da companhia-alvo, os demais acionistas seriam "espremidos" para fora (squeezed out ${ }^{87}$ ), por meio de: (i) uma segunda oferta pública de aquisição de ações com valores inferiores aos da primeira oferta; ou (ii) incorporação da companhia-alvo em outra companhia existente detida pelo recém adquirente do controle da companhia-alvo. ${ }^{88}$

Sendo assim, as ações da companhia-alvo que não fossem adquiridas na oferta pública eram substituídas por ações da incorporadora, sendo que esta última era quase sempre uma companhia com valores mobiliários subordinados (junk bonds). Dessa maneira, realizava-se a clássica "two tier takeover ${ }^{\$ 89}{ }^{90}$, operação de tomada de controle que conjugava uma oferta

\footnotetext{
${ }^{85}$ Ibid. p. 81-82.

${ }^{86}$ Ibid. p. 82.

87 "The term squeezeouts is sometimes used interchangeably with freezouts, but may have a different connotation: a transaction or set of transactions that does not coerce the noncontrolling shareholder in any formal legal sense, but that has the purpose and practical effect of making his situation so unrewarding that he is virtually disinvested or so unpleasant that he will inevitably sell out on the insider's terms." (CLARK, Robert Charles. Corporate Law. Boston/Toronto: Little, Brown and Company, 1986. p. 500).

${ }^{88}$ NASCIMENTO, João Pedro Barroso do. Medidas Defensivas à Tomada de Controle de Companhias. São Paulo: Quartier Latin, 2011. p. 82.

89 "In a two tier offer, the offeror makes a bid for bare control at one price and, if successful, then effects a freezeout merger of remaining shareholders, usually at a lower price. One argument developed, for example, by Professor Bebchuck - is that these practices lead to a distorted choice. Target shareholders may tender because they fear they will be left out of a sale at premium price and will become minority shareholders who are (relatively) poorly treated, not because they think the offeror's bid price reflects the company's full value. Put another way, a single owner of control of the target, not being affected by such strategic considerations, might demand and get a higher price for the target's shares." (CLARK, Robert Charles. Corporate Law. Boston/Toronto: Little, Brown and Company, 1986. p. 545-546).
} 
pública seguida de: (i) uma outra oferta para aquisição das ações remanescentes por valor inferior ao da oferta anterior em que se adquiriu o controle (back-end); ou (ii) incorporação da companhia-alvo em outra companhia (squeeze out merger). ${ }^{91}$

O sucesso desse tipo de operação se dava, evidentemente, pela coerção que era imposta aos acionistas da companhia-alvo de aderirem à oferta pública realizada pelo ofertante. Isso ocorria, porque os acionistas poderiam acabar enfrentando uma incorporação logo após a tomada de controle, na qual suas ações seriam substituídas por junk bonds. Ou então, poderiam acabar se tornando proprietários de ações sem liquidez no mercado e, no caso, essas ações atrairiam apenas o interesse do recém adquirente do controle. ${ }^{92}$

Tendo isso em vista, foi criado nos EUA o Williams Act ${ }^{93}$ de 1968, que alterou o Securities Exchange Act de 1934, com a finalidade de combater as Saturday Night Specials. ${ }^{94}$

\section{Conforme afirmou SUBRAMANIAN:}

The Williams Act, passed by Congress in 1968, substantially reduces a bidder's ability to make a structurally coercive offer. Rule $14 \mathrm{e}-1$, promulgated by the SEC under the authority of the Act, requires that all tender offers stay open for at least twenty business days, thus eliminating the possibility of Saturday Night Specials. Rule 14d-8 requires an acquirer to purchase all shares on a pro rata basis if the offer is oversubscribed. And Rule 14d-10, the "all-holders rule," requires the acquirer to open its tender offer to all shareholders, and to pay all those who tender the same best price..$^{95}$

\footnotetext{
90 "In a two-tier, highly coercive tender offer, the threat is obvious: shareholders may be compelled to tender to avoid being treated adversely in the second stage of the transaction." (Paramount Communications, Inc. v. Time, Inc. 571 A.2d 1140, Delaware, 1990, Rel. Horsey).

${ }^{91}$ NASCIMENTO, João Pedro Barroso do. Medidas Defensivas à Tomada de Controle de Companhias. São Paulo: Quartier Latin, 2011. p. 82.

${ }^{92}$ Ibid. p. 83.

93 "In the United States, tender offers are primarily regulated by the Williams Act, which added certain sections to the Securities Exchange Act, by state takeover statutes, and by general corporate law doctrines." (CLARK, Robert Charles. Corporate Law. Boston/Toronto: Little, Brown and Company, 1986. p. 533).

${ }^{94}$ NASCIMENTO, João Pedro Barroso do. Medidas Defensivas à Tomada de Controle de Companhias. São Paulo: Quartier Latin, 2011. p. 83.

${ }^{95}$ SUBRAMANIAN, Guhan. Bargaining in the Shadow of Takeover Defenses. Yale Law Journal, Vol. 113, Issue 3. December, 2003. p. 631. Disponível em: <http://papers.ssrn.com/sol3/papers.cfm?abstract_id=442721 >. Acesso em: 10/03/2016.
} 
O Williams Act, portanto, pôs fim à epidemia de tomadas de controle, sob a forma de Saturday Night Specials, mas não representou o fim das ofertas públicas para a tomada de controle hostil. Essas ofertas continuaram existindo, tanto que os administradores de companhias tiveram que dedicar mais tempo para orientar os acionistas em relação às ofertas, inclusive, adotando mecanismos de proteção. ${ }^{96}$

Após o Williams Act, os EUA vivenciou o auge das tomadas de controle e dos mecanismos de proteção. Na década de 1980, diversas companhias abertas norte-americanas receberam oferta hostil. As ofertas normalmente consistiam em uma tentativa de obtenção de lucros rápidos $(\text { bust-up })^{97}$, por meio da venda imediata de ativos e/ou segmentos de atuação da companhia-alvo. ${ }^{98}$

O período do wild west capitalism, como ficou conhecido nos EUA, interrompeu-se, dentre outros motivos, após a alteração dos regimes jurídicos implementados por diferentes estados norte-americanos, por meio de leis e regras aplicáveis aos mecanismos de proteção. ${ }^{99}$

\subsection{1 - Williams Act}

Promulgado em 1968, o Williams Act foi uma resposta a uma onda de tentativas de aquisição hostis coercitivas, principalmente, de ofertas públicas para aquisição de controle. As ofertas, muitas vezes, compeliam os acionistas a venderem suas participações acionárias em um curto intervalo de tempo. ${ }^{100}$

Nas palavras de CLARK:

\footnotetext{
${ }^{96}$ NASCIMENTO, João Pedro Barroso do. Medidas Defensivas à Tomada de Controle de Companhias. São Paulo: Quartier Latin, 2011. p. 84-85.

97 “'As we noted in Moran, a 'bust-up' takeover generally refers to a situation in which one seeks to finance an acquisition by selling off pieces of the acquired company, presumably at a substantial profit." (Revlon Inc. v. Macandrews \& Forbes Holdings, Inc. 506 A.2d 173, Delaware, 1986, Rel. Moore. Nota de rodapé $n^{\circ} 12$ ).

${ }^{98}$ NASCIMENTO, João Pedro Barroso do. Medidas Defensivas à Tomada de Controle de Companhias. São Paulo: Quartier Latin, 2011. p. 85.

${ }^{99}$ Ibid. p. 86.

100 The Williams Act: a Truly "Modern" Assessment. Disponível em: $<$ http://corpgov.law.harvard.edu/wp-content/uploads/2011/10/The-Williams-Act-A-TrulyModern-Assessment.pdf>. Acesso em: 08/02/2016.
} 
The argument was advanced that investors faced with a bid for their shares were no less entitled to an opportunity to make a rational investment decision based on all the relevant information than were investors facing a proxy contest or exchange offer. Congress apparently bought this argument, for in 1968 it passed the Williams Act, which amended the Securities Exchange Act of 1934. The Williams Act added Sections 13(d)-(e) and 14(d)-(e) of the Exchange Act. It deals with both acquisitions of control through market purchases and with acquisitions through tender offers, and places similar disclosure requirements on the two types of acquisitions. In addition, some provisions subject tender offers to further regulations designed to relieve investors of some of the pressure attendant on offers limited with respect to time or number of shares requested. Ultimately, the Act sought to place tender offers under regulations designed to give investors the same protections that are accorded investors facing proxy contests or exchange offers, but was not intended, however, either to encourage or discourage tender offers. ${ }^{101}$

O Williams Act foi criado para proteger os investidores que enfrentavam dilemas graves quando corporate raiders realizavam ofertas para assumir o controle das companhias. A lei foi destinada a preencher lacunas na legislação societária federal e estadual norte-americana, já que leis federais de valores mobiliários já haviam incluído requisitos de divulgação para as proxy-fights e share-for-share exchanges, enquanto não havia leis aplicáveis às ofertas públicas de aquisição de controle.

O congresso reconheceu que aquisições de controle de companhias poderiam beneficiar acionistas e a economia como um todo, e também reconheceu que impedir indevidamente a aquisição de grandes blocos de ações poderia ser prejudicial ao mercado. $\mathrm{O}$ congresso americano, portanto, procurou equilibrar os interesses dos administradores, potenciais compradores e acionistas. ${ }^{102}$

\subsection{2 - Securities Exchange Act of 1934, Sections 13 (d) e 14 (d)}

Quando o mercado acionário caiu em outubro de 1929, assim como a confiança do público no mercado norte-americano, o congresso realizou audiências para identificar os problemas e buscar soluções. Com base nisso, no ano de pico da Depressão, aprovou o Securities Act of 1933. E ainda, no

${ }^{101}$ CLARK, Robert Charles. Corporate Law. Boston/Toronto: Little, Brown and Company, 1986. p. 547.

102 The Williams Act: a Truly "Modern" Assessment. Disponível em: <http://corpgov.law.harvard.edu/wp-content/uploads/2011/10/The-Williams-Act-A-TrulyModern-Assessment.pdf>. Acesso em: 08/02/2016. 
ano seguinte, aprovou o Securities Exchange Act of 1934, que criou a Securities and Exchange Commission (SEC).

Os principais objetivos dessas leis são os seguintes: (i) as empresas que oferecem valores mobiliários para venda ao público investidor devem dizer a verdade sobre o seu negócio, sobre os valores mobiliários que estão vendendo, e os riscos envolvidos no investimento; e (ii) aqueles que vendem e negociam valores mobiliários - corretores, distribuidores, etc. devem tratar os investidores de forma justa e honesta. ${ }^{103}$

Nota-se que a SEC tem, portanto, o papel de (i) proteger os investidores de valores mobiliários; (ii) manter o mercado de capitais justo, ordenado e eficiente; e (iii) facilitar a formação de capital. ${ }^{104}$

O Williams Act, conforme exposto anteriormente, por conta do grande número de aquisições hostis ocorridas na década de 60 , veio a integrar a Securities and Exchange Act, notadamente nos artigos 13 (d) e 14 (d).

O dispositivo 13 (d) estabelece para aquele que adquire 5\% das ações de uma companhia, o dever de prestar, no prazo de dez dias a contar da aquisição, uma série de informações (ex.: fonte dos recursos utilizados para a compra, o propósito da aquisição, etc.). Essas informações devem ser prestadas à companhia, à SEC e à bolsa de valores em que a companhia possui listagem. ${ }^{105}{ }_{-} 106$

\footnotetext{
103 The Role of the SEC. Disponível em: <https://www.investor.gov/introduction-markets/rolesec>. Acesso em: 08/02/2016.

104 The Investor's Advocate: How the SEC Protects Investors, Maintains Market Integrity, and Facilitates Capital Formation. Jun. 2013. Disponível em: <https://www.sec.gov/about/whatwedo.shtml >. Acesso em: 08/02/2016.

${ }^{105}$ TOLEDO, Paulo Fernando Campos Salles de. Poison pill: Modismo ou Solução? In: CASTRO, Rodrigo R. Monteiro de; ARAGÃO, Leandro Santos de (Coord.). Direito Societário - Desafios Atuais. São Paulo: Quartier Latin, 2009. p. 169.

${ }^{106}$ Sec. 13 (d)(1) Any person who, after acquiring directly or indirectly the beneficial ownership of any equity security of a class which is registered pursuant to section 12 of this title, or any equity security of an insurance company which would have been required to be so registered except for the exemption contained in section $12(\mathrm{~g})(2)(\mathrm{G})$ of this title, or any equity security issued by a closed-end investment company registered under the Investment Company Act of 1940 or any equity security issued by a Native Corporation pursuant to section 37(d)(6) of the Alaska Native Claims Settlement Act, or otherwise becomes or is deemed to become a beneficial owner of any of the foregoing upon the purchase or sale of a security-based swap that the Commission may define by rule, and is directly or indirectly the beneficial owner of more than 5 per centum of such class
} 


\title{
O 14 (d) prevê que será considerada ilegal qualquer oferta de
} aquisição de ações se, após consumada, o ofertante se tornar titular de 5\%

\author{
das ações, sem que sejam apresentadas as informações acima. ${ }^{107}$
}

shall, within ten days after such acquisition or within such shorter time as the Commission may establish by rule, file with the Commission, a statement containing such of the following information, and such additional information, as the Commission may by rules and regulations, prescribe as necessary or appropriate in the public interest or for the protection of investors - (A) the background, and identity, residence, and citizenship of, and the nature of such beneficial ownership by, such person and all other persons by whom or on whose behalf the purchases have been or are to be effected; (B) the source and amount of the funds or other consideration used or to be used in making the purchases, and if any part of the purchase price is represented or is to be represented by funds or other consideration borrowed or otherwise obtained for the purpose of acquiring, holding, or trading such security, a description of the transaction and the names of the parties thereto, except that where a source of funds is a loan made in the ordinary course of business by a bank, as defined in section 3(a)(6) of this title, if the person filing such statement so requests, the name of the bank shall not be made available to the public; (C) if the purpose of the purchases or prospective purchases is to acquire control of the business of the issuer of the securities any plans or proposals which such persons may have to liquidate such issuer, to sell its assets to or merge it with any other persons, or to make any other major change in its business or corporate structure; (D) the number of shares of such security which are beneficially owned, and the number of shares concerning which there is a right to acquire, directly or indirectly, by (i) such person, and (ii) by each associate of such person, giving the background, identity, residence, and citizenship of each such associate; and (E) information as to any contracts, arrangements, or understandings with any person with respect to any securities of the issuer, including but not limited to transfer of any of the securities, joint ventures, loan or option arrangements, puts or calls, guaranties of loans, guaranties against loss or guaranties of profits, division of losses or profits, or the giving or withholding of proxies, naming the persons with whom such contracts, arrangements, or understandings have been entered into, and giving the details thereof. (2) If any material change occurs in the facts set forth in the statement filed with the Commission, an amendment shall be filed with the Commission, in accordance with such rules and regulations as the Commission may prescribe as necessary or appropriate in the public interest or for the protection of investors. (3) When two or more persons act as a partnership, limited partnership, syndicate, or other group for the purpose of acquiring, holding, or disposing of securities of an issuer, such syndicate or group shall be deemed a "person'" for the purposes of this subsection. (4) In determining, for purposes of this subsection, any percentage of a class of any security, such class shall be deemed to consist of the amount of the outstanding securities of such class, exclusive of any securities of such class held by or for the account of the issuer or a subsidiary of the issuer. (5) The Commission, by rule or regulation or by order, may permit any person to file in lieu of the statement required by paragraph (1) of this subsection or the rules and regulations thereunder, a notice stating the name of such person, the number of shares of any equity securities subject to paragraph (1) which are owned by him, the date of their acquisition and such other information as the Commission may specify, if it appears to the Commission that such securities were acquired by such person in the ordinary course of his business and were not acquired for the purpose of and do not have the effect of changing or influencing the control of the issuer nor in connection with or as a participant in any transaction having such purpose or effect. (6) The provisions of this subsection shall not apply to- (A) any acquisition or offer to acquire securities made or proposed to be made by means of a registration statement under the Securities Act of 1933; (B) any acquisition of the beneficial ownership of a security which, together with all other acquisitions by the same person of securities of the same class during the preceding twelve months, does not exceed 2 per centum of that class; (C) any acquisition of an equity security by the issuer of such security; (D) any acquisition or proposed acquisition of a security which the Commission, by rules or regulations or by order, shall exempt from the provisions of this subsection as not entered into for the purpose of, and not having the effect of, changing or influencing the control of the issuer or otherwise as not comprehended within the purposes of this subsection.

${ }^{107}$ Sec. 14 (d)(1) It shall be unlawful for any person, directly or indirectly, by use of the mails or by any means or instrumentality of interstate commerce or of any facility of a national securities 


\section{4 - O pioneirismo do advogado Joseph Flom}

exchange or otherwise, to make a tender offer for, or a request or invitation for tenders of, any class of any equity security which is registered pursuant to section 12 of this title, or any equity security of an insurance company which would have been required to be so registered except for the exemption contained in section $12(\mathrm{~g})(2)(\mathrm{G})$ of this title, or any equity security issued by a closed-end investment company registered under the Investment Company Act of 1940, if, after consummation thereof, such person would, directly or indirectly, be the beneficial owner of more than 5 per centum of such class, unless at the time copies of the offer or request or invitation are first published or sent or given to security holders such person has filed with the Commission a statement containing such of the information specified in section 13(d) of this title, and such additional information as the Commission may by rules and regulations prescribe as necessary or appropriate in the public interest or for the protection of investors. All requests or invitations for tenders or advertisements making a tender offer or requesting or inviting tenders, of such a security shall be filed as a part of such statement and shall contain such of the information contained in such statement as the Commission may by rules and regulations prescribe. Copies of any additional material soliciting or requesting such tender offers subsequent to the initial solicitation or request shall contain such information as the Commission may by rules and regulations prescribe as necessary or appropriate in the public interest or for the protection of investors, and shall be filed with the Commission not later than the time copies of such material are first published or sent or given to security holders. Copies of all statements, in the form in which such material is furnished to security holders and the Commission, shall be sent to the issuer not later than the date such material is first published or sent or given to any security holders. (2) When two or more persons act as a partnership, limited partnership, syndicate, or other group for the purpose of acquiring, holding, or disposing of securities of an issuer, such syndicate or group shall be deemed a "person" for purposes of this subsection. (3) In determining, for purposes of this subsection, any percentage of a class of any security, such class shall be deemed to consist of the amount of the outstanding securities of such class, exclusive of any securities of such class held by or for the account of the issuer or a subsidiary of the issuer. (4) Any solicitation or recommendation to the holders of such a security to accept or reject a tender offer or request or invitation for tenders shall be made in accordance with such rules and regulations as the Commission may prescribe as necessary or appropriate in the public interest or for the protection of investors. (5) Securities deposited pursuant to a tender offer or request or invitation for tenders may be withdrawn by or on behalf of the depositor at any time until the expiration of seven days after the time definitive copies of the offer or request or invitation are first published or sent or given to security holders, and at any time after sixty days from the date of the original tender offer or request or invitation, except as the Commission may otherwise prescribe by rules, regulations, or order as necessary or appropriate in the public interest or for the protection of investors. (6) Where any person makes a tender offer, or request or invitation for tenders, for less than all the outstanding equity securities of a class, and where a greater number of securities is deposited pursuant thereto within ten days after copies of the offer or request or invitation are first published or sent or given to security holders than such person is bound or willing to take up and pay for, the securities taken up shall be taken up as nearly as may be pro rata, disregarding fractions, according to the number of securities deposited by each depositor. The provisions of this subsection shall also apply to securities deposited within ten days after notice of an increase in the consideration offered to security holders, as described in paragraph (7), is first published or sent or given to security holders. (7) Where any person varies the terms of a tender offer or request or invitation for tenders before the expiration thereof by increasing the consideration offered to holders of such securities, such person shall pay the increased consideration to each security holder whose securities are taken up and paid for pursuant to the tender offer or request or invitation for tenders whether or not such securities have been taken up by such person before the variation of the tender offer or request or invitation. (8) The provisions of this subsection shall not apply to any offer for, or request or invitation for tenders of, any security- (A) if the acquisition of such security, together with all other acquisitions by the same person of securities of the same class during the preceding twelve months, would not exceed 2 per centum of that class; (B) by the issuer of such security; or (C) which the Commission, by rules or regulations or by order, shall exempt from the provisions of this subsection as not entered into for the purpose of, and not having the effect of, changing or influencing the control of the issuer or otherwise as not comprehended within the purposes of this subsection. 
Conforme afirmou o advogado certa vez:

There is an old Chinese wish: "May you live in interesting times." It may be a curse or a blessing. For those practicing in this arena, I feel it is safe to say it undoubtedly will be both; - either way, will certainly be interesting. ${ }^{108}$

O jornalista GLADWELL em seu livro "Outliers - The Story of Success" "109 expôs um pouco da história de Joseph Flom (21 de dezembro, 1923 - 23 de fevereiro, 2011), um dos advogados mais influentes de sua época em matéria de aquisições hostis de controle. Em 1999, ele foi inserido na lista dos advogados do século ("lawyers of the century") pela revista The American Lawyer. ${ }^{110}$

Flom cresceu no Brooklyn, no estado de Nova Iorque. Estudou no City College em Upper Manhattan e, mais tarde, na Universidade de Direito de Harvard. Foi contratado para a Skadden, Arps, Slate, Meagher \& Flom LLP (denominação atual) como associado até se tornar sócio da firma, que hoje é considerada uma das mais poderosas do mundo.

As bancas de advocacia mais cobiçadas de sua época (as "white shoe firms") raramente se envolviam em aquisições de controle hostis por considera-las operações deselegantes. Nessa época, entretanto, Flom já era especialista em aquisições hostis e em batalhas por procurações (proxy fights), trabalho que até então poucos queriam fazer.

Fato é que, na década de 1970, os mercados se internacionalizaram e os investidores se tornaram mais agressivos. $\mathrm{O}$ resultado foi um aumento no número e tamanho de aquisições hostis. De meados de 1970 até o fim dos anos 1980, o mercado de fusões e aquisições em Wall Street atingiu o ápice de US\$ 250 bilhões. ${ }^{111}$

\footnotetext{
${ }^{108}$ FLOM, Joseph H. Mergers \& Acquisitions: The Decade in Review. University of Miami Law Review. 2000. $\quad$ p. $781 . \quad$ Disponível $\langle$ http://repository.law.miami.edu/cgi/viewcontent.cgi?article=1593\&context=umlr $>$. Acesso em: 09/05/2016.

109 GLADWELL, Malcolm. Fora de Série - Outliers. Tradução de Ivo Korytowski. Rio de Janeiro: Sextante, 2008.

110 Joe timeline. Disponível em: <http://www.skadden.com/newsletters/Joe_Flom_Timeline.pdf >. Acesso em: 09/05/2016.

111 GLADWELL, Malcolm. Fora de Série - Outliers. Tradução de Ivo Korytowski. Rio de Janeiro: Sextante, 2008. p. 121.
} 
Nas palavras de GLADWELL, “de uma hora para outra, tudo aquilo que os escritórios de advocacia não queriam lidar - tomadas hostis de controle e litígios - tornou-se o trabalho que todo escritório de advocacia desejava executar". 112

Com isso, Flom, pela reputação e experiência de longa data, tornouse, antes de todos, a referência e a preferência dos clientes em matéria de aquisições hostis de controle, o que contribuiu muito para a enorme ascensão da Skadden, Arps.

O maior concorrente de Joseph Flom era o escritório Wachtell, Lipton, Rosen \& Katz. Diferentemente dos grandes escritórios de advocacia de Nova Iorque, como o Skadden, Arps, que possui centenas de advogados atuando nas maiores capitais do mundo, o Wachtell, Lipton opera apenas no centro de Manhattan. Sua sede está instalada no prédio comercial de grande prestígio, conhecido como BlackRock. ${ }^{113}$

Martin Lipton é um dos sócios do escritório. Ele frequentou escolas públicas de New Jersey, depois a universidade da Pensilvânia, e por fim, a faculdade de Direito da Universidade de Nova Iorque. Foi ele quem formulou a poison pill em 1982. ${ }^{114}$ Martin Lipton e Joseph Flom representaram clientes de lados opostos em casos de aquisição de controle e medidas defensivas, e representaram uma nova era para o mundo das fusões e aquisições. ${ }^{115}$

\footnotetext{
${ }^{112}$ Ibid. p. 121.

${ }^{113}$ Ibid. p. 146.

114 "In September 1982, Mr. Lipton published a memorandum describing the 'Warrant Dividend Plan.' The 'warrant' was a security that could be issued by the board of directors of a target company that would have the effect of increasing the time available to the board to react to an unsolicited bid and allow the board to maintain control over the process of responding to the bid. In various forms it was used successfully by targets of hostile bids in 1982 and 1983 to gain time and maximize shareholder value. In 1983, Mr. Lipton's plan was christened with the unfortunate name 'poison pill' by an investment banker who had nothing to do with its creation." (LIPTON, Martin; ROWE, Paul K. Pills, Polls, and Professors: A Reply to Professor Gilson. The Delaware Journal of Corporate Law, Vol. 27, No. 1, pp. 1-55, 2002. Disponível em: <http://papers.ssrn.com/sol3/papers.cfm?abstract_id=398060>. Acesso em: 15/05/2016. p. 14-15). 115 "Joseph Flom, who spearheaded the $1983-85$ attacks on the pill, has observed that ' $[\mathrm{t}]$ he Nineties . . . have seen almost total acceptance of hostile takeover activity, with domestic hostile bids being made by major establishment firms such as GE, AT\&T, IBM, Pfizer and AlliedSignal." (LIPTON, Martin; ROWE, Paul K. Pills, Polls, and Professors: A Reply to Professor Gilson. The Delaware Journal of Corporate Law, Vol. 27, No. 1, pp. 1-55, 2002. Disponível em:
} 
Flom representou uma série de clientes em casos famosos, como (i) Anheuser-Busch em sua aquisição pela InBev; (ii) Ronald Perelman em sua aquisição não solicitada da Revlon; (iii) Chemical Bank em sua defesa contra uma tentativa de aquisição hostil por Saul Steinberg; (iv) Marshall Field and Co. em sua defesa contra as propostas de aquisição hostil de Carter Hawley Hale e de Carl Icahn; (v) U.S. Steel em sua defesa contra a campanha do Sr. Icahn contra a Companhia; e (vi) T. Boone Pickens e Mesa Petroleum em uma tentativa de aquisição hostil da Unocal. ${ }^{116}$

\section{5 - As ofertas coercitivas sob a ótica da teoria dos jogos}

A teoria dos jogos, conforme MANKIW, é o estudo de como as pessoas se comportam em situações estratégicas. Estratégia, nesse caso, refere-se a situações em que um indivíduo, quando precisa escolher entre determinadas alternativas, deve considerar a reação das outras pessoas à decisão tomada. A teoria dos jogos ajuda a explicar as estratégias que as pessoas escolhem, seja no âmbito de um jogo de pôquer, seja no âmbito das aquisições hostis e das medidas de proteção. ${ }^{117}$

Para o estudo dessa teoria, outro conceito importante a ser destacado é o do Equilíbrio de Nash, nome dado em homenagem ao economista que ganhou o prêmio Nobel de Economia em $1994^{118}$, John Nash, cuja história de vida foi retratada no filme "A beautiful mind"119. Um equilíbrio de Nash é uma situação em que os agentes econômicos que estão interagindo uns

\footnotetext{
$<$ http://papers.ssrn.com/sol3/papers.cfm?abstract_id=398060>. Acesso em: 15/05/2016. Nota de rodapé $\mathrm{n}^{\circ} 59$ ).

116 Disponível em: <https://www.skadden.com/news-events/joseph-h-flom-ma-pioneer-andphilanthropist-dies-87>.

〈http://www.skadden.com/newsletters/Flom_Additional_Information.pdf $>$ Acesso em: 11/02/2016.

${ }^{117}$ MANKIW, N. Gregory. Tradução de Allan Vidigal Hastings, Elisete Paes e Lima. Introdução à Economia. Título original: Principles of economics. 5. ed. norte-americana. São Paulo: Cengage Learning, 2009. p. 349-350.

${ }^{118}$ Ibid. p. 360.

119 A BEAUTIFUL MIND. Direção de Ron Howard. Estados Unidos: Universal Pictures/DreamWorks Pictures/Imagine Entertainment. 2001. A versão brasileira foi intitulada "Uma mente brilhante".
} 
com os outros escolhem a melhor estratégia para si com base nas estratégias escolhidas pelos outros. ${ }^{120 \_121}$

Antes de expor a situação enfrentada pelos investidores em face das ofertas coercitivas, faz-se necessário, por questões didáticas, tratar de um problema da teoria dos jogos conhecido como o dilema dos prisioneiros, um jogo entre dois prisioneiros que ilustra como é difícil manter a cooperação, mesmo quando esta é mutuamente benéfica. ${ }^{122}$

Conforme MANKIW ${ }^{123}$, o dilema dos prisioneiros é uma história de dois criminosos que foram capturados pela polícia. Por questões didáticas, os criminosos vão ser chamados de prisioneiro $\mathrm{X}$ e prisioneiro $\mathrm{Y}$. O caso é o seguinte: a polícia possui provas suficientes para condená-los a um ano de prisão pelo crime de porte ilegal de armas. A polícia também suspeita que os dois tenham cometido um assalto a banco juntos, mas não têm evidências concretas para condená-los por esse outro crime. A polícia os interroga em salas separadas e propõe a cada um deles o seguinte acordo:

Até este momento, podemos prendê-lo por um ano. Entretanto, se você confessar o assalto a banco e acusar seu comparsa, nós lhe daremos imunidade e você ficará livre. Seu cúmplice passará 20 anos na cadeia. Mas, se vocês dois confessarem o crime, não precisaremos de seu testemunho e poderemos economizar os custos do julgamento, de modo que vocês dois receberão uma pena intermediária de 8 anos. $^{124}$

Visto isso, cada prisioneiro tem duas estratégias: confessar ou ficar em silêncio. A sentença de cada um dependerá de sua própria estratégia e da estratégia escolhida por seu cúmplice no crime. ${ }^{125}$

Considerar-se-á a hipótese de o prisioneiro $\mathrm{X}$ entender que, independentemente do que o prisioneiro Y faça, a sua melhor estratégia é

\footnotetext{
${ }^{120}$ MANKIW, N. Gregory. Tradução de Allan Vidigal Hastings, Elisete Paes e Lima. Introdução à Economia. Título original: Principles of economics. 5. ed. norte-americana. São Paulo: Cengage Learning, 2009. p. 352.

${ }^{121}$ NASH, John. Non-cooperative games. Annals of Mathematics. Vol. 54, No., September, 1951. p. 286-295.

${ }^{122}$ MANKIW, N. Gregory. Tradução de Allan Vidigal Hastings, Elisete Paes e Lima. Introdução à Economia. Título original: Principles of economics. 5. ed. norte-americana. São Paulo: Cengage Learning, 2009. p. 354.

${ }^{123}$ Ibid. p. 354-355.

${ }^{124}$ Ibid. p. 354

${ }^{125}$ Ibid. p. 354.
} 
confessar. Isso, porque, em seu raciocínio: (i) ele não sabe o que o prisioneiro $\mathrm{Y}$ vai fazer. Se o prisioneiro $\mathrm{Y}$ permanecer em silêncio, sua melhor estratégia é confessar, já que assim ficará livre, sem ter que passar um ano na prisão; e (ii) se o prisioneiro $\mathrm{Y}$ confessar, ainda assim sua melhor estratégia é confessar, já que passará 8 anos na cadeia ao invés de $20 . .^{126}$

$\mathrm{Na}$ linguagem da teoria dos jogos, um estratagema é chamado de estratégia dominante se é a melhor para um dos jogadores, independentemente das estratégias utilizadas pelos demais. Nesse caso, confessar é uma estratégia dominante para o prisioneiro X. Ele passará menos tempo na cadeia se confessar, independentemente de o prisioneiro $\mathrm{Y}$ confessar ou permanecer em silêncio. ${ }^{127}$

O prisioneiro $\mathrm{Y}$, por sua vez, raciocina de maneira semelhante. Independentemente do que o prisioneiro $\mathrm{X}$ faça, o prisioneiro $\mathrm{Y}$ pode reduzir seu tempo na prisão se confessar. Sendo assim, confessar também é uma estratégia dominante para o prisioneiro $\mathrm{Y} .{ }^{128}$

No fim das contas, tanto o prisioneiro $\mathrm{X}$ quanto o prisioneiro $\mathrm{Y}$ confessam e cada um passa 8 anos na cadeia. Ainda assim, esse seria um péssimo resultado. Se os dois tivessem permanecido em silêncio, ambos estariam em uma melhor situação, passando apenas um ano na cadeia por porte ilegal de armas. Ao perseguirem seus interesses próprios, os dois chegam juntos a um resultado que é pior para ambos. Essa é a chave do dilema. ${ }^{129}$

Visto isso, no âmbito de uma oferta pública hostil para aquisição de controle, é possível que um acionista opte pela venda de suas ações, por um preço não desejado, justamente por não saber qual decisão os demais acionistas irão tomar. Se os demais acionistas optam por vender suas ações, o ofertante adquire o controle. Com isso, pode ser que o acionista tenha que

\footnotetext{
${ }^{126}$ Ibid. p. 354.

${ }^{127}$ Ibid. p. 354-355.

${ }^{128}$ Ibid. p. 355.
} 
enfrentar uma segunda oferta subsequente por um preço ainda menor por ação, ou até uma incorporação da companhia-alvo, mediante a substituição das ações por junk bonds. Ao enfrentar a oferta coercitiva, sem saber como os demais acionistas irão agir, acaba vendendo suas ações em uma primeira oferta por um preço indesejado, obtendo assim um pior resultado para si. Caso não tivesse agido individualmente, e tivesse cooperado com os demais, poderia ter obtido um melhor resultado fazendo o que é melhor para si e para os outros.

Sobre isso, vale destacar o exposto por VILARINHO BORGES, PETRI BERNARDES, COMETTI e NAKAYAMA:

As configurações são inúmeras, com os mais diferentes nomes, descabendo aqui uma abordagem extensiva do assunto, nos interessando destacar aqui o fundamento de seu surgimento: a constatação, dada pela teoria dos jogos, de que o acionista perde ao agir individualmente, ganhando muito mais com a cooperação. De fato, diante de uma oferta de aquisição, o acionista, individualmente, acaba enfrentando algumas possibilidades muito ruins: a) não vender na primeira etapa da oferta e acabar compelido a vender em uma segunda, com preço inferior (second-tier price); b) não vender e acabar com uma participação minoritária em uma companhia de baixa liquidez, caso o adquirente consiga a grande maioria das ações; c) ser ainda mais diluído ou ter o preço da ação ainda mais desvalorizado em uma operação societária subsequente, de incorporação ou fusão (freeze out/squeeze out). Assim, diante do desconhecimento acerca do comportamento dos demais, só resta ao acionista a estratégia dominante de venda na primeira oferta, por mais que ele entenda que o preço não é adequado. A cláusula estatutária denominada de poison pill surgiria, nessa perspectiva, para garantir que o acionista não se sinta compelido a vender, estabelecendo, usualmente, procedimentos para: a) negociação coletiva do preço a ser pago para aqueles que aceitarem a oferta; b) garantia de igualdade para aqueles que quiserem aceitar a oferta; c) mecanismos de defesa, caso se conclua pela rejeição da oferta. Ademais, a existência da poison pill desestimula também a escalada em bolsa, garantindo que um investidor não se aproveite da dispersão acionária para tomar facilmente o controle da companhia. ${ }^{130}$

\section{6 - Tratamento legal brasileiro}

No ordenamento jurídico brasileiro, os artigos 257 a 263 da Lei das S.A., bem como a Instrução CVM n 361/02 ("ICVM 361”) regulam as ofertas públicas para a aquisição de controle.

\footnotetext{
${ }^{129}$ Ibid. p. 355 .

${ }^{130}$ VILARINHO BORGES, Leandro; PETRI BERNARDES, Lucas; COMETTI, Marcelo Tadeu; NAKAYAMA, Wilson. A poison pill brasileira: proteção da dispersão acionária ou reforço do poder de controle? Revista de direito mercantil, industrial, econômico e financeiro. Ano L. julhodezembro/2011. Editora Malheiros. p. 231-232.
} 
A Lei das S.A. estabelece as seguintes situações que ensejam a realização de oferta pública de aquisição obrigatória: (i) o cancelamento de registro da companhia (artigo $4^{\circ}, \S 4^{\circ}$ ); (ii) o aumento de participação do acionista controlador da companhia (artigo $4^{\circ}, \S 6^{\circ}$ ); e (iii) a alienação do controle da companhia aberta (artigo 254-A).

As ofertas públicas voluntárias, por outro lado, são realizadas não por cumprimento de um ato normativo, mas por decorrência da intenção do ofertante de adquirir ações mediante apelo ao público de vendedores. ${ }^{131}$

Conforme EIZIRIK destaca, a oferta pública prevista no artigo $257^{132}$ deve ser intermediada por uma instituição financeira (underwriter) que garanta o cumprimento das obrigações assumidas pelo ofertante. A instituição atua como garantidora da oferta, assegurando ao mercado a viabilidade da proposta realizada pelo ofertante. Isso evita o surgimento de ofertas temerárias ou meramente especulativas que possam causar danos aos investidores e afetar o funcionamento normal do mercado. ${ }^{133}$

Em regra, a oferta pública para a aquisição de controle de companhia aberta não se sujeita a registro prévio na Comissão de Valores Mobiliários (CVM). No entanto, de acordo com o $\S 1^{\circ}$ do artigo 257 , será submetida a registro na CVM apenas a oferta pública para aquisição de controle que contiver permuta, total ou parcial, dos valores mobiliários.

Ainda, conforme o $\S 2^{\circ}$ do mesmo artigo, a oferta pública para a aquisição de controle terá por objeto ações com direito a voto em número

\footnotetext{
${ }^{131}$ EIZIRIK, Nelson. A Lei das S/A Comentada. Volume III. São Paulo: Quartier Latin, 2011. p. 457.

${ }^{132}$ Art. 257. A oferta pública para aquisição de controle de companhia aberta somente poderá ser feita com a participação de instituição financeira que garanta o cumprimento das obrigações assumidas pelo ofertante. $\S 1^{\circ}$ Se a oferta contiver permuta, total ou parcial, dos valores mobiliários, somente poderá ser efetuada após prévio registro na Comissão de Valores Mobiliários. $\S 2^{\circ} \mathrm{A}$ oferta deverá ter por objeto ações com direito a voto em número suficiente para assegurar o controle da companhia e será irrevogável. $\S 3^{\circ}$ Se o ofertante já for titular de ações votantes do capital da companhia, a oferta poderá ter por objeto o número de ações necessário para completar o controle, mas o ofertante deverá fazer prova, perante a Comissão de Valores Mobiliários, das ações de sua propriedade. $\S 4^{\circ}$ A Comissão de Valores Mobiliários poderá expedir normas sobre oferta pública de aquisição de controle.

${ }^{133}$ EIZIRIK, Nelson. A Lei das S/A Comentada. Volume III. São Paulo: Quartier Latin, 2011. p. 468.
} 
suficiente para assegurar o controle da companhia, sendo tal oferta irrevogável. Isso também está previsto na ICVM 361. ${ }^{134}$

Se o ofertante já for titular de ações votantes da companhia, a oferta poderá ter por objeto o número de ações necessárias para assegurar o controle da companhia. Cabendo ao titular dessas ações, no entanto, fazer prova das ações em sua propriedade perante a CVM.

Adicionalmente, o artigo $262^{135}$ prevê a possibilidade de se realizar oferta pública concorrente. Essa oferta se caracteriza por aquela formulada por um terceiro que tenha por objeto ações abrangidas pela oferta pública anterior cujo edital já tenha sido publicado. Essa oferta também deve observar os requisitos constantes dos artigos 257 a 263 da Lei das S.A.

Por fim, é importante que, no âmbito da oferta pública para a aquisição de controle, para que os acionistas possam refletir antes de tomar a decisão de aderir ou não à oferta, a administração da companhia exponha sua opinião favorável ou desfavorável sobre a aceitação da proposta, justificando os motivos para tal opinião.

A ICVM 361, em seu artigo 32-D, prevê que, caso o conselho de administração da companhia objeto decida se manifestar de modo favorável ou contrário à aceitação da OPA para aquisição de controle: (i) a manifestação deverá abordar todos os aspectos relevantes para a decisão do investidor, sobretudo o preço oferecido na OPA; (ii) a manifestação deve descrever as alterações relevantes na situação financeira da companhia objeto ocorridas desde a data das últimas demonstrações financeiras ou informações trimestrais divulgadas ao mercado; e (iii) a cópia da

\footnotetext{
134 Art. 32. A OPA voluntária para a aquisição do controle de companhia aberta, de que trata o art. 257 da Lei 6.404/76, somente dependerá de registro na CVM caso envolva permuta por valores mobiliários, e observará o seguinte: [...] III - a OPA deverá ter por objeto, pelo menos, uma quantidade de ações capazes de, somadas às do ofertante, de pessoas a ele vinculadas, e que com ele atuem em conjunto, assegurar o controle de companhia aberta.

135 Art. 262. A existência de oferta pública em curso não impede oferta concorrente, desde que observadas as normas desta Seção. $\S 1^{\circ}$ A publicação de oferta concorrente torna nulas as ordens de venda que já tenham sido firmadas em aceitação de oferta anterior. $\S 2^{\circ}$ É facultado ao primeiro ofertante prorrogar o prazo de sua oferta até fazê-lo coincidir com o da oferta concorrente.
} 
manifestação deverá ser divulgada ao mercado por meio de sistema eletrônico disponível na página da CVM na rede mundial de computadores. 


\section{CAPÍTULO 3 - OS MECANISMOS DE PROTEÇÃO CONTRA A TOMADA HOSTIL DE CONTROLE}

\section{1 - Breves considerações}

Antes de estudar os diferentes mecanismos de proteção contra a tomada hostil de controle, é necessário destacar que, no Brasil, há uma febre na inserção das chamadas cláusulas de proteção à dispersão acionária nos estatutos sociais das mais diversas companhias, que vêm sendo equivocadamente chamadas de poison pills.

$\mathrm{Na}$ verdade, a poison pill, originalmente concebida nos EUA, consiste apenas em uma espécie do gênero das medidas "afasta-tubarão" (shark repellents). ${ }^{136 \_137}$

Os shark repellents, conforme a doutrina norte-americana, nada mais são que disposições inseridas nos estatutos sociais de companhias com o objetivo de deter/evitar eventual aquisição hostil de controle. ${ }^{138}$

\section{Conforme MÜSSNICH e LOBÃO MELO:}

Poison pill nada mais é do que a nomenclatura dada para um tipo de medida defensiva criada nos Estados Unidos, mas que em nada se assemelha com a variação tupiniquim incorporada em alguns estatutos sociais de companhias brasileiras, uma evidente confusão de espécie com gênero. ${ }^{139}$

\footnotetext{
136 MÜSSNICH, Francisco Antunes Maciel; HENRIQUE PERES, Fábio. Administração deve colaborar para o melhor uso das poison pills. Out. de 2008. Disponível em: <http://www.bmalaw.com.br/arquivos/Artigos/Numero\%2025.pdf>. Acesso em: 13/02/2016.

137 " "[...] there is a large set of precautions that can be taken before particular tender offer is about to be made. Many of these precautions require amendment of the corporation's charter and therefore a sharehoder vote. They are often called 'shark repellents"'. (CLARK, Robert Charles. Corporate Law. Boston/Toronto: Little, Brown and Company, 1986. p. 576).

138 Sobre isso ver: FRIEDENBERG, Ellen S. Jaws III: The impropriety of shark-repellent amendments as a takeover defense. Disponível em: <http://www.djcl.org/wpcontent/uploads/2014/07/Jaws-III-THE-IMPROPRIETY-OF-SHARK-REPELLENT-

AMENDMENTS-AS-A-TAKEOVER-DEFENSE1.pdf>. Acesso em: 07/05/2016.

${ }^{139}$ MÜSSNICH, Francisco Antunes Maciel; LOBÃO MELO, Vitor de Britto. Análise Prática e Considerações sobre a realidade e a aplicação das medidas de proteção à tomada de controle nos estatutos sociais das companhias abertas brasileiras (Brazilian Pills). In: SILVA, Alexandre Couto (Coord.). Direito Societário - Estudos sobre a lei de sociedades por ações. 2013. Editora Saraiva. Disponível

em:

<http://www.bmalaw.com.br/arquivos/Artigos/DIREITO\%20SOCIET\%C3\%81RIO\%20\%20ESTUDOS\%20SOBRE\%20A\%20LEI\%20DE\%20SOCIEDADES\%20POR\%20A\%C3\%87\% C3\%95ES.PDF>. Acesso em: 15/05/2016. p. 254.
} 
É importante notar, apenas por questões didáticas, que os mecanismos de proteção em geral podem ser classificados como preventivos ou posteriores ${ }^{140}$. Os preventivos são aqueles adotados previamente a uma eventual tentativa de tomada de controle. Os posteriores, como o próprio termo já diz, são aqueles adotados depois de ter sido iniciada uma aquisição de controle. Essa distinção é importante para os fins de análise do poder-dever da administração em relação à adoção das medidas de proteção.

Face ao exposto, far-se-á a apresentação de algumas espécies de mecanismos de proteção.

\section{2 - Pílulas de veneno (poison pills)}

O mecanismo de poison pill, como já dito anteriormente, foi criado pelo advogado norte-americano Martin Lipton em 1982, e teve larga utilização nos Estados Unidos dos anos 80. ${ }^{141}{ }_{-}^{142}$

Essas medidas são conhecidas como pílulas de veneno (poison pills), pois logo após o seu "disparo", tornam o controle da companhia tão oneroso para o adquirente, que acabam por, se não dificultar, impossibilitar a aquisição do controle da companhia-alvo.

\section{Como bem afirma JENSEN:}

Poison pill securities change fundamental aspects of the corporate rules that govern the relationship between shareholders, managers, and the board of directors when a control-related event occurs. They are called "poison pills" because they alter the company to make it indigestible to an acquirer. ${ }^{143}$

Sobre as posion pills afirma CLARK:

\footnotetext{
140 NASCIMENTO, João Pedro Barroso do. Medidas Defensivas à Tomada de Controle de Companhias. São Paulo: Quartier Latin, 2011. p. 118-121.

141 SHIGUEMATSU, Plínio José Lopes. Mecanismos de proteção e estratégias de defesa em tomadas hostis de controle. In: CASTRO, Rodrigo R. Monteiro de; ARAGÃO, Leandro Santos de (coord.). Direito Societário - Desafios Atuais. São Paulo: Quartier Latin, 2009. p. 399.

${ }^{142}$ Sobre isso, também ver: COSTA, Len. The Perfect Pill. A small innovation that transformed corporate takeovers. Legal Affairs. Abril de 2005. Disponível em: <http://www.legalaffairs.org/issues/March-April-2005/toa_costa_marapr05.msp>. Acesso em: 07/02/2016.

143 JENSEN, Michael C. Jensen. Takeovers: Their Causes and Consequences. Journal of Economic Perspectives, Winter 1988, Vol. 2, No. pp. 21-48. Disponível em: <http://papers.ssrn.com/sol3/papers.cfm?abstract_id=173455>. Acesso em: 07/02/2016.
} 
[...] Yet another species of share manipulation is the "poison pill" plan. (It might be adopted before or after a hostile tender offer is imminent, so it is not necessarily a post-offer tactic.) As originally conceived, it was to be effective against two-tier takeover attempts, in which the acquirer first makes a tender offer not for all shares but for a controlling interest, with the intent or possibility of later freezing out the remaining shareholders, perhaps at a lower price. There are several varieties, three of which will be mentioned. $[\ldots]^{144}$

As poison pills clássicas, originalmente concebidas nos Estados Unidos, são planos de direitos atribuíveis aos acionistas, que preveem que o lançamento de uma oferta pública de aquisição de controle, tendo por objetivo certa companhia-alvo e/ou a aquisição de participação acionária para além de limites de participação acionária previstos, sem o aval da administração, atribui aos demais acionistas direitos de aquisição ou subscrição de ações, usualmente, a preços bem inferiores àqueles usualmente praticados pelo mercado. ${ }^{145}$

CLARK cita três versões de planos de poison pill, que são as seguintes: (i) a Conversion rights version; (ii) a Redemption rights version; e (iii) a Rights plan version. ${ }^{146}$

Sobre a Conversion rights version, CLARK afirma:

First, the target's board might cause it to create a new class of preferred stock and distribute shares of it to the common stockholders as a stock dividend. The charter provisions defining the rights of the preferred would say that the company could not consummate certain transactions, such as a merger with another entity or a transfer of substantially all assets, unless the acquirer undertook to comply with certain provisions of the preferred stock contract. Under these provisions the preferred stock would become convertible into voting stock of the acquirer. The conversion ratio would reflect the highest acquisition price paid by the acquirer or, if higher, the current market value of the target's stock. If the plan worked as intended, it would reduce the incentives of target shareholders to tender, since they might think they had nothing to lose by waiting. ${ }^{147}$

Em outras palavras, e conforme explica NASCIMENTO, os planos de poison pill, em sua forma original e primeira versão mencionada por CLARK (a Conversion rights version), consistem em dividendos

\footnotetext{
${ }^{144}$ CLARK, Robert Charles. Corporate Law. Boston/Toronto: Little, Brown and Company, 1986. p. 574.

${ }^{145}$ NASCIMENTO, João Pedro Barroso do. Medidas Defensivas à Tomada de Controle de Companhias - São Paulo: Quartier Latin, 2011. p. 136.

${ }^{146}$ CLARK, Robert Charles. Corporate Law. Boston/Toronto: Little, Brown and Company, 1986. p. 574-575.
} 
distribuídos aos acionistas ordinários da companhia-alvo, por meio de pagamento em ações preferenciais sem direito a voto. Essas ações preferenciais seriam conversíveis em ações ordinárias no caso de eventual tomada de controle. ${ }^{148}$

Já sobre a segunda versão das poison pills, a Redemption rights version, CLARK afirma:

Second, the target might issue preferred stock in which the poisonous aspect resided in the stock's redemption rights instead of its conversion rights. Suppose, for example, the preferred stockholders is empowered to compel the target to redeem her preferred shares at any time within 30 days after a "stock acquisition date." The latter is defined to occur when anyone acquires a certain amount, e. g., 40 percent, of the target's equity. The redemption price is based on the highest price the acquirer paid for the common stock of the target, plus all unpaid dividends on the preferred. This feature might deter the hostile bidder because if it gained control, it might find itself with a company that had just seriously depleted its assets in order to redeem the preferred. Obviously, this problem could be made even more serious if the redemption price were set arbitrarily high - say, three times the acquirer's acquisition price - but then the plan might be much harder to justify if subjected to legal attack. Mixing our metaphors in the wild manner that is customary when discussing takeovers, we might say that this second type of poison pill embodies a "scorched earth" policy. ${ }^{149}$

Nessa versão, o aspecto venenoso da pílula está no direito de resgate das ações, ao invés do direito de conversão. A companhia-alvo, nesse caso, diante de uma oferta hostil, pode conceder direitos aos acionistas preferenciais, por exemplo, de resgatar suas ações a preços altos. Isso torna a aquisição desinteressante ao potencial adquirente, tendo em vista a quantidade de recursos da companhia que seriam destinados ao pagamento do resgate das ações dos acionistas preferenciais.

A terceira versão e atualmente mais popular é conhecida nos EUA como Shareholders Rights Plan. CLARK descreve esse modelo da seguinte forma:

A third poison pill involves giving the target's common shareholders, as a dividend on their shares, "rights" or warrants instead of preferred stock. The governing document might provide that the rights could be detached and sold

\footnotetext{
${ }^{147}$ Ibid. p. 574.

148 NASCIMENTO, João Pedro Barroso do. Medidas Defensivas à Tomada de Controle de Companhias. São Paulo: Quartier Latin, 2011. p. 136.

${ }^{149}$ CLARK, Robert Charles. Corporate Law. Boston/Toronto: Little, Brown and Company, 1986. p. 575 .
} 
separately from the common on which they were issued when a person or group acquired 20 percent of the target's common, or when a tender offer for 30 percent of the common was announced. The holder of a right would be entitled to buy new preferred stock on certain terms or, in the event of a merger of which the target was not the survivor, $\$ 200$ worth of the acquiring company's equity for $\$ 100$ ! Thus, an offeror corporation making a classic two-tiered offer might find the interests of its own preexisting shareholders being substantially diluted. ${ }^{150}$

Nessa última versão, ao invés de valores mobiliários conversíveis em ações votantes, a companhias-alvo distribui, como dividendos aos seus acionistas, direitos que autorizam todos eles (exceto o adquirente do controle) a adquirirem ações de emissão desta última, em condições privilegiadas, durante um prazo determinado. ${ }^{151}$

Basicamente, as poison pills, sob a forma de Shareholders Rights Plan, estabelecem que eventual oferta para a tomada de controle, possibilitará a adoção pela administração da companhia-alvo de programa de recompra de ações de sua emissão; ou aos acionistas da companhia-alvo, direito de resgate de suas ações ou de aquisição e/ou subscrição de ações, normalmente, por preços inferiores aos praticados pelo mercado. ${ }^{152}$

Conforme NASCIMENTO, esses programas de poison pill, em geral, estabelecem que a eficácia de tais direitos atribuídos aos acionistas está suspensivamente condicionada à ocorrência do evento que disparará o "gatilho", momento a partir do qual estará autorizado o exercício de tais direitos. Normalmente, este evento que dispara o "gatilho" consiste no anúncio da oferta pública de aquisição de controle, que visa adquirir determinado percentual do capital social da companhia-alvo e/ou aumento de participação acionária para além desse percentual. ${ }^{153}$

Um exemplo está na fala do inescrupuloso personagem Gordon Gekko, interpretado pelo ator Michael Douglas no filme "Wall Street" (1987), quando ele tenta tomar o controle de uma companhia sem disparar o gatilho de uma eventual poison pill (o próprio diretor Oliver Stone, nos

\footnotetext{
${ }^{150}$ Ibid. p. 575.

151 NASCIMENTO, João Pedro Barroso do. Medidas Defensivas à Tomada de Controle de Companhias. São Paulo: Quartier Latin, 2011. p. 137.

152 Ibid. p. 137.
} 
comentários sobre o filme, disse que o personagem tratava, nesta cena, de questões ligadas a poison pills) $)^{154 \_}{ }^{155}$ :

Listen Jerry, I'm looking for negative control. No more than 30, 35\%. Just enough to block anybody else's merger plans, and find out if the books are cooked. If it looks as good as on paper, we're in the kill zone, pal. Lock and load.

Note-se, portanto, que, de uma forma geral, as poison pills, visam (i) dificultar ou desestimular a aquisição do controle; e (ii) criar mecanismos que protejam os acionistas, estabelecendo procedimentos ou direitos que permitam um maior prazo de resposta pela companhia, ganhando um prazo para análise adequada ou mais aprofundada da oferta pública. ${ }^{156}$

\subsection{1 - Flip in}

Conforme NASCIMENTO, são mecanismos de defesa em que certos acionistas da companhia-alvo empreendem esforços e utilizam-se de direitos conferidos pela poison pill para: (i) diluir o potencial adquirente; e/ou (ii) aumentar a quantidade de ações que ele deverá adquirir para tomar o controle. ${ }^{157}$

Nesses casos, permite-se que os acionistas, exceto o ofertante, tenham a possibilidade de (i) adquirir ações de emissão da própria companhia-alvo, mantidas em tesouraria, por um preço inferior ao valor de mercado, o que dificulta a aquisição de controle pelo ofertante; ou (ii) subscreverem ações emitidas em eventual aumento de capital social da companhia-alvo, por valores inferiores aos do mercado. ${ }^{158}$

\subsection{2 - Flip over}

\footnotetext{
${ }^{153}$ Ibid. p. 137.

${ }^{154}$ WALL STREET. Direção de Oliver Stone; Produção de Edward R. Pressman. Estados Unidos: Twentieth Century Fox Film Corporation. 1987. 1 DVD (125 minutos), Color. A versão brasileira foi intitulada "Wall Street - poder e cobiça".

${ }^{155}$ Sobre isso ver: RIBSTEIN, Larry E. Imagining Wall Street. Virginia Law and Business Review, Vol. $1, \quad$ p. $\quad 165, \quad 2006 . \quad$ Disponível em: <http://papers.ssrn.com/sol3/papers.cfm?abstract_id=771724\#\#>. Acesso em: 10/03/2016.

${ }^{156}$ SHIGUEMATSU, Plínio José Lopes. Mecanismos de proteção e estratégias de defesa em tomadas hostis de controle. In: CASTRO, Rodrigo R. Monteiro de; ARAGÃO, Leandro Santos de (Coord.). Direito Societário - Desafios Atuais. São Paulo: Quartier Latin, 2009. p. 398.

157 NASCIMENTO, João Pedro Barroso do. Medidas Defensivas à Tomada de Controle de Companhias. São Paulo: Quartier Latin, 2011. p. 142.

${ }^{158}$ Ibid. p. 142-143
} 
Conforme NASCIMENTO explica, essa modalidade diz respeito a mecanismos de defesa, por meio dos quais são atribuídos direitos aos acionistas da companhia-alvo, que lhes assegurarão proteção em caso de tentativa de tomada de controle, mediante aquisição de ações do terceiro adquirente por um preço significativamente abaixo do valor de mercado.

Ou seja, nessa modalidade, a companhia-alvo dá direito aos demais acionistas de adquirirem ações do próprio ofertante a um preço bastante inferior após a aquisição, procurando assim transferir o controle do ofertante para os seus próprios acionistas.

Esta defesa se contrapõe às two tier takeovers, já que os direitos atribuídos aos acionistas da companhia-alvo poderão ser exercidos no caso de o recém adquirente do controle realizar uma operação de concentração empresarial logo após a aquisição de controle. ${ }^{159}$

\section{3 - Cláusulas de proteção à dispersão acionária (Brazilian pills)}

No Brasil, nota-se que há um movimento por parte das companhias de inserção de cláusulas de proteção à dispersão acionária (Brazilian pills) que, conforme dito anteriormente, vêm sendo equivocadamente chamadas de poison pills.

Essas medidas que vêm sendo adotadas no Brasil, geralmente, preveem que qualquer acionista e/ou terceiro que adquirir ou, de qualquer outro modo, tornar-se titular de ações de emissão da companhia, em quantidade igual ou superior a determinado percentual do total de ações, deverá realizar oferta pública de aquisição de ações para adquirir a totalidade das ações da companhia.

\section{Como explica CARVALHOSA:}

A poison pill estatutária mais utilizada pelas companhias abertas brasileiras consiste em cláusula estabelecendo que a aquisição de determinado percentual de ações de emissão da companhia no mercado $(15 \%, 20 \%, 25 \% \ldots)$ gera, para o

\footnotetext{
${ }^{159}$ Ibid. p. 147.
} 
adquirente, o dever de realizar Oferta Pública de Aquisição de ações (OPA) dirigida a todos os demais acionistas. ${ }^{160}$

Segue abaixo um exemplo de cláusula de proteção à dispersão acionária:

Artigo 32 - Qualquer Pessoa, que adquira ou se torne titular de ações de emissão da Companhia, em quantidade igual ou superior a 15\% (quinze por cento) do total de ações de emissão da Companhia ("Pessoa Relevante") deverá, no prazo máximo de 60 (sessenta) dias a contar da data de aquisição ou do evento que resultou na titularidade de ações em quantidade igual ou superior a 15\% (quinze por cento) do total de ações de emissão da Companhia, realizar uma oferta pública de aquisição da totalidade das ações de emissão da Companhia ("OPA"), observando-se o disposto na regulamentação aplicável da CVM, o Regulamento do Novo Mercado, outros regulamentos da BM\&FBOVESPA e os termos deste Artigo.

Parágrafo $1^{\circ}$ - A OPA deverá ser: (i) dirigida indistintamente a todos os acionistas da Companhia; (ii) efetivada em leilão a ser realizado na BM\&FBOVESPA; (iii) lançada pelo preço determinado de acordo com o previsto no Parágrafo $2^{\circ}$ deste Artigo; e (iv) paga à vista, em moeda corrente nacional, contra a aquisição na OPA de ações de emissão da Companhia.

Parágrafo $2^{\circ}$ - O preço de aquisição na OPA de cada ação de emissão da Companhia não poderá ser inferior ao maior valor entre (i) $125 \%$ (cento e vinte e cinco por cento) da cotação unitária mais alta atingida pelas ações de emissão da Companhia durante o período de 12 (doze) meses anterior à realização da OPA em qualquer bolsa de valores em que as ações da Companhia forem negociadas; (ii) $125 \%$ (cento e vinte e cinco por cento) do preço unitário mais alto pago pela Pessoa Relevante, a qualquer tempo, para uma ação ou lote de ações de emissão da Companhia; e (iii) o Valor Econômico apurado em laudo de avaliação. [... ${ }^{161}$

A finalidade dessa disposição estatutária é, de certa maneira, proteger a companhia contra ofertas hostis, ao tornar demasiadamente oneroso o aumento de participação acionária para além dos limites estabelecidos no estatuto.

Com relação ao preço de aquisição, percebe-se que o dispositivo acima estabelece critérios de avaliação que fazem com que o preço fique

160 CARVAlHOSA, Modesto. As Poison Pills Estatutárias na Prática Brasileira - Alguns Aspectos de sua Legalidade. In: CASTRO, Rodrigo R. Monteiro de; ARAGÃO, Leandro Santos de (Coord.). Direito Societário - Desafios Atuais. São Paulo: Quartier Latin, 2009. p. 25.

${ }^{161}$ Extraído do estatuto social de uma companhia aberta disponível na central de sistemas da CVM. Optou-se, neste trabalho, por não expor o nome da companhia em questão, embora a informação seja pública. 
muito elevado ${ }^{162}$, ou por vezes proibitivo ${ }^{163}$, o que acaba de fato desestimulando o eventual ofertante.

\section{Conforme MÜSSNICH e LOBÃO MELO:}

Há exemplos de redação que beiram o escárnio, onde se pode constatar a evidente intenção de impedir ou, ao menos, tornar excessivamente onerosa a aquisição de controle.

[...] Ao nosso ver, dificultar uma aquisição é estabelecer um preço razoavelmente acima da avaliação de um determinado bem causando no candidato a adquirente uma dúvida e uma necessária análise de conveniência, prudência e possibilidade de se pagar o preço pedido ante a ordem de grandeza estabelecida.

No entanto, o que pode se perceber em algumas Brazilian pills é que o preço calculado atinge valores astronômicos e se mostra evidentemente inalcançável e impagável.

Tais cláusulas que, por vezes, mostram-se excessivamente onerosas, tornando quase impossível a aquisição de controle, vêm sendo adotadas pelas mais diversas companhias brasileiras, inclusive, aquelas submetidas ao controle concentrado sem perspectivas de serem submetidas a estruturas de dispersão acionária.

\subsection{1 - Cláusulas acessórias}

Observa-se que as Brazilian pills, certas vezes, vêm acompanhadas de algumas cláusulas acessórias que são, de certa forma, questionáveis, como aquela que prevê a suspensão dos direitos do acionista que descumprir com a Brazilian pill.

Um exemplo contido no mesmo estatuto social da companhia anterior é o seguinte:

Parágrafo $5^{\circ}$ - Na hipótese da Pessoa Relevante não cumprir com as obrigações impostas por este Artigo, inclusive no que concerne ao atendimento dos prazos máximos (i) para a realização da OPA; ou (ii) para atendimento das eventuais solicitações ou exigências da CVM, ou com as obrigações previstas no Artigo 33

162 CARVAlHOSA, Modesto. As Poison Pills Estatutárias na Prática Brasileira - Alguns Aspectos de sua Legalidade. In: CASTRO, Rodrigo R. Monteiro de; ARAGÃO, Leandro Santos de (coord.). Direito Societário - Desafios Atuais. São Paulo: Quartier Latin, 2009. p. 25.

163 MÜSSNICH, Francisco Antunes Maciel; LOBÃO MELO, Vitor de Britto. Análise Prática e Considerações sobre a realidade e a aplicação das medidas de proteção à tomada de controle nos estatutos sociais das companhias abertas brasileiras (Brazilian Pills). In: SILVA, Alexandre Couto (Coord.). Direito Societário - Estudos sobre a lei de sociedades por ações. 2013. Editora Saraiva. Disponível

em:

<http://www.bmalaw.com.br/arquivos/Artigos/DIREITO\%20SOCIET\%C3\%81RIO\%20\%20ESTUDOS\%20SOBRE\%20A\%20LEI\%20DE\%20SOCIEDADES\%20POR\%20A\%C3\%87\% C3\%95ES.PDF>. Acesso em: 15/05/2016. p. 258. 
deste Estatuto, o Conselho de Administração da Companhia convocará Assembleia Geral Extraordinária, na qual a Pessoa Relevante não poderá votar, para deliberar sobre a suspensão do exercício dos direitos da Pessoa Relevante que não cumpriu com qualquer obrigação imposta por este Artigo, conforme disposto no Artigo 120 da Lei das Sociedades por Ações, sem prejuízo da responsabilidade da Pessoa Relevante por perdas e danos causados aos demais acionistas em decorrência do descumprimento das obrigações impostas por este Artigo.

\section{Conforme MÜSSNICH e LOBÃO MELO analisam, a punição} prevista pode ocorrer tanto pelo descumprimento da Brazilian pill como um todo, como pelo descumprimento de pequenas regras procedimentais, como a do prazo acima citado, que pode, muitas vezes, não ser razoável. ${ }^{164}$ Outro ponto estabelecido no dispositivo é a determinação ex ante de conflito de interesses na manifestação do voto do acionista que tenha descumprido a Brazilian pill na assembleia geral convocada para deliberar sobre a determinada suspensão de seus direitos. ${ }^{165}$

O entendimento de MÜSSNICH e LOBÃO MELO ${ }^{166}$, bem como o da Lei das S.A. ${ }^{167}$ e seus autores, LAMY FILHO e BULHÕES PEDREIRA $^{168}$, é de que eventual conflito de interesses só pode ser

\footnotetext{
${ }^{164}$ MÜSSNICH, Francisco Antunes Maciel; LOBÃO MELO, Vitor de Britto. Análise Prática e Considerações sobre a realidade e a aplicação das medidas de proteção à tomada de controle nos estatutos sociais das companhias abertas brasileiras (Brazilian Pills). In: SILVA, Alexandre Couto (Coord.). Direito Societário - Estudos sobre a lei de sociedades por ações. 2013. Editora Saraiva. Disponível em: <http://www.bmalaw.com.br/arquivos/Artigos/DIREITO\%20SOCIET\%C3\%81RIO\%20\%20ESTUDOS $\% 20$ SOBRE $\% 20 \mathrm{~A} \% 20$ LEI $\% 20 \mathrm{DE} \% 20$ SOCIEDADES $\% 20 \mathrm{POR} \% 20 \mathrm{~A} \% \mathrm{C} 3 \% 87 \%$ C3\%95ES.PDF>. Acesso em: 15/05/2016. p. 263.

165 Ibid. p. 263-264.

166 Ibid. p. 264.

${ }^{167}$ Conforme o art. $115, \S 4^{\circ}$ da Lei das S.A.: " $\S 4^{\circ}$ A deliberação tomada em decorrência do voto de acionista que tem interesse conflitante com o da companhia é anulável (grifo nosso); o acionista responderá pelos danos causados (grifo nosso) e será obrigado a transferir para a companhia as vantagens que tiver auferido (grifo nosso)."

168 "O $\S 1^{\circ}$ do artigo 115 relaciona o conflito de interesses como caso de proibição de voto. No entanto, o $\S 4^{\circ}$ do mesmo artigo dispõe que a deliberação tomada em decorrência do voto em conflito é anulável. Apesar da aparência de proibição e de discrepância entre as normas, pressupõe a LSA que o acionista possa exercer o voto mesmo em conflito. Esse é o entendimento majoritário da doutrina, escorada também no direito comparado. A interpretação correta dos dispositivos da LSA é a de que o conflito de interesses não pode ser determinado a priori, a não ser nas hipóteses de conflito formal, semelhantes ao que a doutrina italiana chama de divieto de voto, já discutidas no $§ 105$ (laudo de avaliação, aprovação de contas como administrador e deliberações que beneficiem o acionista de modo particular). Nesses casos, a lei prevê o conflito impeditivo de voto e, como remédio preventivo, proíbe o voto independentemente do exame do mérito. O simples fato de o acionista encontrar-se na situação descrita pela lei impede o direito de voto. O conflito de interesses, no entanto, não é matéria que possibilite o pré-julgamento do voto. Tanto é que a própria LSA admite, por exemplo, o contrato da sociedade com o acionista (ou mesmo com o
} 
analisado e verificado a posteriori, ou seja, após a manifestação do voto do acionista, considerando os critérios de relevância, comutatividade e interesse da companhia. ${ }^{169}$

Em relação a isso inclusive, é interessante a questão levantada pela Ex-Diretora da CVM Ana Dolores Moura Carneiro de Novaes, ao tratar do direito de voto e sua vedação, em seu voto vencedor no caso da CVM envolvendo operações societárias para a união das atividades da Portugal Telecom SGPS S.A. e da Oi S.A.:

60. E não poderia ser diferente. No Direito Societário, o princípio majoritário é a regra do regime de funcionamento dos órgãos da companhia. As deliberações são tomadas por maioria de votos e, quando conformes com a lei e o estatuto social, vinculam todos os membros, ainda que ausentes ou dissidentes. O princípio majoritário é uma exigência do interesse social, que não pode ser prejudicado pelos interesses e vontades individuais.

61. Aproveito o ensejo para contrapor um argumento frequentemente lançado por aqueles que defendem, no caso concreto, a vedação de voto dos acionistas controladores. Segundo este argumento, caso a operação seja positiva para a companhia, os minoritários terão todo interesse de aprová-la. Acredito que o raciocínio seja perfeito num mundo em que as posições acionárias são sempre compradas. O raciocínio, contudo não se mantém, no mundo dos comprados e vendidos, dos fundos long and short e quanto estruturas envolvendo contratos derivativos podem levar à separação entre o interesse econômico e o poder político. Não necessariamente há um alinhamento de interesses nestes casos. ${ }^{170}$

administrador), nos artigos $117, \S 1^{\circ}$, letra (f), e $156, \S 1^{\circ}$. São casos em que acionista (ou administrador) e companhia estão em posições contrapostas (e, formalmente, em conflito), e nem por isso estão impedidos previamente de agir. São vigiados de perto, com seu direito circunscrito por normas dispositivas que, uma vez quebradas, permitem a anulação do negócio e a cobrança dos danos havidos. Essa é também a regra que vale para o conflito de interesses no exercício do direito de voto. A existência do conflito constitui uma quaestio facti, nas palavras de Eizirik (1998, p. 109), a ser apreciada caso a caso, após exame da deliberação. Mesma opinião tem Valverde (1953, v. II, n. 454), comentando o artigo 95 do Decreto-lei $n^{\circ}$ 2.627/1940. Lacerda Texeira; Tavares Guerreiro (1979, v.1, p. 278) concordam que, devido à larga abrangência da última parte do $\S 1^{\circ}$ do artigo 115 , a identificação da circunstância de conflito de interesses realmente só pode ser dar à vista do caso concreto. A lei trata, nesse particular, do conflito substancial, não do conflito formal. Tanto é assim que a sanção legal é a anulabilidade do voto, tal qual o abuso do direito de voto, e não a nulidade, como nas hipóteses de conflito de interesse formal (v. § 105). No mesmo sentido, Barros Leães (2004b, v. I, p. 179); Novaes França (1993, p. 92-93; e, comentando o artigo 95 do Decreto-Lei n ${ }^{\circ}$ 2.627/1940, Guimarães (1960, v. 2, p. 252).” (REGO, Marcelo Lamy. Direito de Voto. In: LAMY FILHO, Alfredo; BULHÕES PEDREIRA, José Luiz. Direito das Companhias. Volume I. Rio de Janeiro: Forense, 2009. p. 422-423).

169 Note-se, no entanto, que a CVM tem se posicionado a favor do chamado "conflito formal", caso em que o impedimento de voto se verifica antes da deliberação, quando determinado acionista tiver interesse conflitante com os demais acionistas. Vide Decisão do Colegiado da CVM de 09/09/2010. Disponível em: <http://www.cvm.gov.br/decisoes/2010/20100909_R1/20100909_D09.html>. Acesso em: 14/02/2016.

${ }^{170}$ CVM. Processo Administrativo CVM No RJ2013/10913. Voto da Diretora Ana Dolores Moura Carneiro de Novaes. 25/03/2014. 
Sobre isso também vale destacar a referência feita pela Ex-Diretora ao relato de STRINE JR a respeito daqueles que se opõem à premissa de que os acionistas minoritários, necessariamente, exercem o seu direito de voto no interesse da companhia.

Many of them view it as likely that money managers - who do not intend to be around when the consequences of corporate policies proposed by activist hedge funds come to fruition - will give great weight to the short-term effect of policies, without adequately considering whether those policies create too little long-term investment or too much leverage and externality risk.

$[\ldots]$

For society as a whole, further empowering money managers with short-term holding periods subjects Americans to lower long-term growth and job creation, wreckage from corporate failures due to excessive risk taking and debt, and the collateral harm caused when corporations face strong incentives to cut regulatory corners to maximize short-term profits. ${ }^{171}$

Feitas essas breves considerações, outra cláusula a ser destacada é aquela coloquialmente referida, pelo mercado, sob o jargão de "cláusula pétrea". Ressalte-se que, por questões práticas, este trabalho utilizará a mesma terminologia usualmente utilizada pela prática societária, ainda que essa não seja a expressão técnica mais adequada.

Tais cláusulas, basicamente, obrigam o acionista que tenha votado a favor da supressão, alteração ou exclusão da cláusula de proteção à dispersão acionária a realizar a oferta pública exigida pelo estatuto social.

Segue abaixo um exemplo de tal cláusula também encontrada no estatuto social da companhia anterior:

Parágrafo 10 - Qualquer alteração deste Estatuto que limite o direito dos acionistas à efetivação da OPA prevista neste Artigo ou a exclusão deste Artigo obrigará os acionistas que tiverem votado a favor de tal alteração ou exclusão na deliberação em Assembleia Geral a efetivar, de forma conjunta e solidária, a OPA prevista neste Artigo.

Note-se que a obrigação de realização de OPA com as condições previstas, sobretudo em relação ao preço, já tem grandes chances de ser considerada desproporcional ao próprio adquirente do controle, imagine

${ }^{171}$ STRINE JR, Leo E. Can We Do Better by Ordinary Investors? A Pragmatic Reaction to the Dueling Ideological Mythologists of Corporate Law. Columbia Law Review. vol. 114, p. 458-459. 
para o acionista titular de poucas ações que, no exercício de seu direito de voto, manifeste-se pela supressão ou alteração da Brazilian pill. ${ }^{172}$

A Comissão de Valores Mobiliários (CVM), apesar de apoiar a utilização das Brazilian pills, já se manifestou contrariamente à utilização das cláusulas pétreas, inclusive, declarou que os acionistas que as violassem não seriam penalizados pelo órgão. ${ }^{173}$

Além disso, em determinada ocasião, o Colegiado da CVM se manifestou no sentido de que as cláusulas pétreas podem apresentar os seguintes problemas jurídicos:

1. Ao impor um ônus significativo aos acionistas que aprovarem a supressão da cláusula de proteção à dispersão acionária, as disposições acessórias podem limitar a soberania da assembléia geral, contrariamente ao que dispõe art. 121 da Lei $n^{\circ} 6.404$, de 15 de dezembro de 1976.

2. Se o objetivo das disposições acessórias for tornar as cláusulas de proteção à dispersão acionária praticamente imutáveis, elas irão de encontro ao disposto no art. 122, I, da Lei $\mathrm{n}^{\circ} 6.404$, de 1976, que outorga poderes à assembléia geral para alterar o estatuto sempre que o interesse social assim o exigir.

3. O efeito prático das disposições acessórias é exigir unanimidade, ou quase unanimidade, para que a cláusula de proteção à dispersão acionária possa ser suprimida. Indiretamente, as disposições acessórias podem aumentar o quorum previsto em lei para essa deliberação social, o que é vedado pelo art. $129, \S 1^{\circ}$, da Lei $\mathrm{n}^{\circ}$ 6.404, de 1976.

4. No limite, as disposições acessórias podem conduzir à violação do art. 115 da Lei $\mathrm{n}^{\circ}$ 6.404, de 1976. Com efeito, o ônus econômico por elas estabelecido pode, na prática, impedir o acionista de exercer seu direito de voto no interesse da companhia, conforme manda a lei. ${ }^{174}$

\section{4 - Greenmail}

\section{Conforme CLARK:}

\footnotetext{
Disponível em: <http://columbialawreview.org/wp-content/uploads/2014/03/Strine-L..pdf . Acesso em: 24/03/2016.

172 MÜSSNICH, Francisco Antunes Maciel; LOBÃO MELO, Vitor de Britto. Análise Prática e Considerações sobre a realidade e a aplicação das medidas de proteção à tomada de controle nos estatutos sociais das companhias abertas brasileiras (Brazilian Pills). In: SILVA, Alexandre Couto (Coord.). Direito Societário - Estudos sobre a lei de sociedades por ações. 2013. Editora Saraiva. Disponível em: <http://www.bmalaw.com.br/arquivos/Artigos/DIREITO\%20SOCIET\%C3\%81RIO\%20\%20ESTUDOS\%20SOBRE\%20A\%20LEI\%20DE\%20SOCIEDADES\%20POR\%20A\%C3\%87\% C3\%95ES.PDF>. Acesso em: 15/05/2016. p. 265-266.

173 Sobre isso ver: Ora, pílulas. Istoé Dinheiro. Julho de 2009. Disponível em: <http://www.istoedinheiro.com.br/noticias/dinheiro-em-acao/20090715/ora-pilulas/12568.shtml>. Acesso em: 08/02/2016.

174 Decisão do Colegiado de 14/04/2009. Disponível em: <http://www.cvm.gov.br/decisoes/2009/20090414_R1/20090414_D04.html>. Acesso em: 03/07/2016.
} 
A more direct repurchase approach is to pay "greenmail," that is, to cause the target company to buy the shares already obtained by the hostile would-be acquirer at a substantial premium over the latter's cost, with the understanding that he, she, or it will stop the takeover attempt. Understandably, other shareholders are likely to be outraged by this tactic. Suppose Targg stock has been selling for around $\$ 50$. Ike files a Schedule 13D that reveals that he has amassed, through open market and privately negotiated purchases, 8 percent of Targg's stock at an average price of $\$ 60$. Reliable rumor has it that Ike is considering a takeover bid at $\$ 75$. In addition to preparing various other defenses, Targg's board negotiates with Ike to sell his shares to Targg at $\$ 90$; Ike will agree not to pursue a takeover. Not only have the other Targg shareholders lost a possible chance to sell at a premium, but they may also find that their shares' value has been diluted by Targg's exorbitant payment to Ike. ${ }^{175}$

Sendo assim, greenmail diz respeito à recompra de ações de um potencial adquirente hostil, com o pagamento de um prêmio por elas, a fim de que ele deixe de comprar novas ações da companhia-alvo. ${ }^{176}{ }^{177}$

Percebe-se que, nesse caso, os demais acionistas da companhia-alvo podem criar óbices a essa operação, tendo em vista que a medida acaba gerando um tratamento desigual entre eles.

No caso Unocal Corp. v. Mesa Petroleum Co., que será analisado adiante, a Suprema Corte de Delaware se referiu à Mesa Petroleum como um "greemailer" de reconhecida reputação nacional. A ironia no caso era que a Mesa Petroleum era o adquirente hostil de controle e alegava que estava sendo tratada de forma desigual, já que somente os demais acionistas poderiam vender as suas ações no âmbito da recompra de ações empreendida pela Unocal como estratégia de defesa.

\section{5 - Cavaleiro branco (white knight)}

\section{Nas palavras de JENSEN:}

[...] "white knight" - a friendly merger partner who will protect the "maiden" from the advances of the feared raider and, more important, who will pay a higher price. ${ }^{178}$

\footnotetext{
175 CLARK, Robert Charles. Corporate Law. Boston/Toronto: Little, Brown and Company, 1986. p. 574.

${ }^{176}$ MARTINS NETO, Carlos. Dispersão Acionária, Tomada Hostil de Controle e Poison Pills: Breves Reflexões. Dezembro de 2009. Disponível em: <http://www.bocater.com.br/UPLOAD/noticias/564d93f37f654.pdf>. Acesso em: 08/02/2016. p. 35 .

177 "The term 'greenmail' refers to the practice of buying out a takeover bidder's stock at a premium that is not available to other shareholders in order to prevent the takeover." (Unocal Corp. v. Mesa Petroleum Co. 493 A.2d 946, Delaware, 1985, Rel. Moore. Nota de rodapé n ${ }^{\circ} 13$ ).
} 
CLARK expõe o seguinte:

A more benign variation, from the shareholders' viewpoint, is target management's search for a "white knight," that is, a rival bidder that will save them from the first offeror by offering both the shareholders and themselves a more attractive deal. ${ }^{179}$

Portanto, essa medida se refere àquela em que um terceiro, convidado da companhia-alvo, realiza uma oferta concorrente à do primeiro ofertante, mais atrativa tanto para companhia-alvo quanto para os acionistas. ${ }^{180}$

Um exemplo de white knight, conforme será exposto mais detalhadamente no próximo capítulo, está no caso paradigmático Revlon, Inc. v. MacAndrews and Forbes Holdings, Inc., em que o Conselho de Administração da Revlon, diante de uma oferta hostil para a tomada de controle da ofertante indesejada Pentry Pride, opta por convidar o cavaleiro branco, a Forstmann Little, para fazer concorrência. Note-se, no entanto, que a Suprema Corte de Delaware entendeu, diante das circunstâncias do caso concreto, que os conselheiros da Revlon favoreceram a Forstmann, em detrimento da Pentry Pride. E ainda, agiram em descordo com seus deveres fiduciários ao encerrarem a disputa e aceitarem a proposta da primeira, ao invés de darem continuidade às propostas e estimularem a maximização do preço das ofertas.

\section{6 - Escudeiro branco (white squire)}

Conforme NASCIMENTO explica, white squire consiste na medida em que são convidados terceiros amigáveis à administração e/ou a determinados grupos de acionistas relevantes da companhia-alvo, para adquirirem participação acionária, a fim de apoiar a administração e/ou

\footnotetext{
178 JENSEN, Michael C. Takeovers: Folklore and Science. Harvard Business Review. Nov-Dec 1984. p. 07. Disponível em: <http://papers.ssrn.com/sol3/papers.cfm?abstract_id=350425>. Acesso em: 10/03/2016.

${ }^{179}$ CLARK, Robert Charles. Corporate Law. Boston/Toronto: Little, Brown and Company, 1986. p. 572.

${ }^{180}$ Ver também: MARTINS NETO, Carlos. Dispersão Acionária, Tomada Hostil de Controle e Poison Pills: Breves Reflexões. Dezembro de 2009. Disponível em:
} 
acionistas relevantes, de modo a protege-los conta ofertas hostis. Essa medida é semelhante à do cavaleiro branco. ${ }^{181}$

\section{Conforme exemplifica SHIGUEMATSU:}

O investidor Warren Buffet é um famoso white squire. Ele conseguiu participações em diversas companhias, através de sua empresa, a Berkshire Hathaway, ao participar como white squire em empresas como Gillette, CocaCola, U.S. Air e Salomon Brothers. Em 1989, ele investiu US\$600 milhões em ações preferenciais conversíveis da Gillette, que após a conversão lhe renderam uma participação de $11 \%$ nas ações com direito a voto. ${ }^{182}$

\section{7 - Pac-man defense}

\section{Conforme CLARK:}

A sixth general category of takeover defenses might be described as "turnabout". For example, the target might respond by making a tender offer for the offeror's shares. Conceivably, they might devour each other - that is, each might wind up liquidating itself to pay the other's shareholders. (This was once described as the Pac Man defense, after a now almost-forgotten computer game. ${ }^{183}$

\section{Ainda lembra JENSEN:}

The Bendix attempt to take control of Martin Marietta in 1982 gained considerable attention because of Marietta's unusual countertakeover offer for Bendix, called the "Pac-Man defense," whose principle is: "My company will eat yours before yours eats mine." Some describe this kind of contest as disgraceful. I find it fascinating because it makes clear that the crucial issue is not whether the two companies will merge but which managers will be in control. ${ }^{184}$

Percebe-se, portanto, que pac-man defense é a medida de defesa da companhia-alvo contra uma oferta hostil, mediante o lançamento de uma contra-oferta visando a aquisição das ações da companhia ofertante. A defesa é assim chamada, pois faz referência a um jogo de vídeo game da década de 80. CLARK, conforme acima, refere-se a essa defesa como turnabout.

\footnotetext{
$\langle$ http://www.bocater.com.br/UPLOAD/noticias/564d93f37f654.pdf >. Acesso em: 08/02/2016. p. 36.

181 NASCIMENTO, João Pedro Barroso do. Medidas Defensivas à Tomada de Controle de Companhias. São Paulo: Quartier Latin, 2011. p. 170.

${ }^{182}$ SHIGUEMATSU, Plínio José Lopes. Mecanismos de proteção e estratégias de defesa em tomadas hostis de controle. In: CASTRO, Rodrigo R. Monteiro de; ARAGÃO, Leandro Santos de (coord.). Direito Societário - Desafios Atuais. São Paulo: Quartier Latin, 2009. p. 430.

${ }^{183}$ CLARK, Robert Charles. Corporate Law. Boston/Toronto: Little, Brown and Company, 1986. p. $575-576$.
} 


\section{8 - Joia da Coroa (crown jewel)}

No sétimo episódio do seriado norte-americano "Suits"185, o personagem Harvey Specter, interpretado pelo ator Gabriel Macht, ao representar seu cliente em uma negociação, foi surpreendido por uma tentativa de tomada de controle hostil. A saída que utilizou foi adotar a medida de defesa joia da coroa. No caso, ele venderia um ativo relevante da companhia-alvo da tomada, um hotel, tornando-a menos desejável ou vantajosa para o potencial adquirente, o que forçou ambas as partes a renegociarem a operação como anteriormente havia sido proposta.

Sendo assim, de acordo definição proposta por NASCIMENTO, entende-se que crown jewel consiste na venda ou na outorga de opção de compra a terceiros, tendo por objeto ativos relevantes da companhia-alvo, referidos como "joia da coroa". Esta defesa visa reduzir a atratividade da companhia-alvo para o ofertante hostil interessado na aquisição de seu controle. ${ }^{186}$

\section{9 - Macaroni defense}

Conforme NASCIMENTO, essa medida consiste na emissão de debêntures emitidas pela companhia-alvo com a obrigação de recompra, com prêmio relevante, no caso de sucesso de oferta hostil para a tomada de controle. ${ }^{187}$

\subsection{0 - Paraquedas dourado (golden parachute)}

\section{Para CLARK:}

[...] the potential target might manufacture "golden parachutes" for its top managers. These are contractual arrangements with the managers whereby very large increases in their compensation will be triggered by a successful takeover bid. The kind of compensation - for example, vested pension benefits - could take many forms. The main idea is that, if the managers are about to be blown out of their cockpits, they might as well float down in style. The parachutes are like

184 JENSEN, Michael C. Takeovers: Folklore and Science. Harvard Business Review. Nov-Dec 1984. p. 03. Disponível em: <http://papers.ssrn.com/sol3/papers.cfm?abstract_id=350425>. Acesso em: 10/03/2016.

185 SUITS. Direção de Kevin Bray. Estados Unidos: Universal Pictures. 2011. Season 1, Episode 7.

186 NASCIMENTO, João Pedro Barroso do. Medidas Defensivas à Tomada de Controle de Companhias. São Paulo: Quartier Latin, 2011. p. 171.

${ }^{187}$ Ibid. p. 181. 
severance pay for ordinary workers, but a lot more generous, of course. Consequently, this technique is more a form of insurance for managers than a true shark repellent. Indeed, some have argued that golden parachutes, unlike many other defensive measures, actually benefit shareholders because they reduce the personal incentive of target managers to stop takeover bids at all costs. Consider, for example, that a series of defensive acquisitions could cost a target and its shareholders much, much more, in terms both of wasteful use of assets and lost opportunities for better management, than a successful takeover that is accompanied by generous payments to departing managers. ${ }^{188}$

A ideia principal é que, se os administradores estão prestes a ser soprados para fora da cabine de comando, eles podem, pelo menos, cair em grande estilo.

Golden parachutes $^{189}$ dizem respeito, portanto, a contratos celebrados pela companhia-alvo e seus altos administradores que estabelecem que, no caso de sucesso de uma eventual aquisição de controle, serão atribuídos aumentos significativos nas compensações econômicas da administração.

Isso representa um custo adicional a ser incorrido pelo adquirente do controle logo após a realização da tomada, o que funciona como um desestímulo na aquisição de tal controle. ${ }^{190}$

\subsection{1 - Conselho de administração escalonado (staggered board)}

\section{Para CLARK:}

Yet another amendment would create a staggered board of directors. For example, a board with 12 directorships, each up for shareholder vote every year (as is normal practice) might be reclassified so that only three positions would be voted on each year. Thus, a hostile offeror that buys a control block might (in theory) have to wait two or three years before it could vote in a majority of the directors, and thus have legal authority to change the management and operations of the target. (In practice, of course, the incumbent directors would often find it in their interest to come to terms with the new controlling shareholder. $)^{191}$

\footnotetext{
${ }^{188}$ CLARK, Robert Charles. Corporate Law. Boston/Toronto: Little, Brown and Company, 1986. p. 577.

189 'In the takeover context 'golden parachutes' generally are understood to be termination agreements providing substantial bonuses and other benefits for managers and certain directors upon a change in control of a company." (Revlon Inc. v. Macandrews \& Forbes Holdings, Inc. 506 A.2d 173, Delaware, 1986, Rel. Moore. Nota de rodapé $n^{\circ} 5$ ).

190 NASCIMENTO, João Pedro Barroso do. Medidas Defensivas à Tomada de Controle de Companhias - São Paulo: Quartier Latin, 2011. p. 177-178.

${ }^{191}$ CLARK, Robert Charles. Corporate Law. Boston/Toronto: Little, Brown and Company, 1986. p. 576.
} 
Sendo assim, diz respeito à medida de proteção em que o conselho de administração é dividido em grupos ou classes, com períodos distintos de mandato. $\mathrm{O}$ estatuto social da companhia-alvo prevê mandato específico para cada um dos membros.

Percebe-se, portanto, conforme nota NASCIMENTO, que eventual adquirente do controle encontrará dificuldades em substituir os membros do conselho de forma imediata, já que seus mandatos não serão unificados. ${ }^{192}$

\subsection{2 - Apenas diga não (just say no)}

Consiste na simples rejeição, pelo conselho de administração, da oferta pública de aquisição de controle. ${ }^{193}$

É mais comum no ambiente norte-americano, pois lá se pressupõe que o poder-dever de decidir em relação à oferta pública compete ao conselho de administração ${ }^{194}$ (board of directors), e não à assembleia geral de acionistas ${ }^{195}$.

\footnotetext{
192 NASCIMENTO, João Pedro Barroso do. Medidas Defensivas à Tomada de Controle de Companhias - São Paulo: Quartier Latin, 2011. p. 164-165.

193 Sobre isso ler: "No Mas" to "Just Say No"? David Fox, Kirkland \& Ellis LLP. Disponível em: <https://corpgov.law.harvard.edu/2010/03/20/no-mas-to-just-say-no/>. Acesso em: 08/02/2016.

194 Sobre os poderes do Conselho de Administração nos Estados Unidos, discorre CLARK, "Shareholders usually elect directors who have the formal legal power to manage the corporation. The directors usually serve one-year terms (and may be re-elected), although many statutes permit a classified board of directors, - for example, nine directors, three of whose terms expire in year one, another three in year two, the other three in year three, and so forth. Directors may be removed by shareholders 'for cause' and, if the statute allows, without cause. As a formal legal matter, the directors, acting as a board at properly called meetings, have extremely broad powers and responsibilities. These include the appointment, supervision, and removal of the officers who actually run the corporation; the fixing of the officers' compensation; the delegation of decision making authority to subcommittees of the board of directors, to the officers, and to others; the decision whether, in their discretion, to declare and pay dividends on the corporation's stock; the adoption, amendment, and repeal of bylaws (a power that may also reside in shareholders); the initiation and approval of certain extraordinary corporate actions, such as amendments to the articles of incorporation, mergers, sales of all assets, and dissolutions, before such matters can be submitted to the shareholders for their approval; and, more generally, the making of major business decisions, such as policies concerning what products and services the company will offer, what prices it will charge and wages it will pay, what major financing agreements it will enter, and the like. In a word, the board is supposed to supervise the entire operation of the business. Directors also have some rights that may be individually exercised: a right to inspect corporate books and records, (called absolute in some states and qualified in others), and, sometimes, a right to bring derivative actions on behalf of the corporation." (CLARK, Robert Charles. Corporate Law. Boston/Toronto: Little, Brown and Company, 1986. p. 105-106).

195 Já sobre as matérias em que os acionistas podem votar em assembleia geral, afirma CLARK, "Sharehoders vote to elect the directors and to approve extraordinary matters like mergers, sales of all assets, dissolutions, and amendments of the articles of incorporation. They may also vote to adopt, amend, and repeal bylaws; to remove directors when cause for doing so exists or the right to
} 
No Brasil, essa decisão compete à assembleia geral, ainda que seja extremamente importante o envolvimento da administração nas operações de aquisição de controle de companhias. Por essas razões, essa medida é praticamente inaplicável no sistema jurídico brasileiro. ${ }^{196}$

remove has been preserved; and to adopt shareholder resolutions, which may ratify board actions or request the board to take certain actions." (Ibid. p. 94)

196 NASCIMENTO, João Pedro Barroso do. Medidas Defensivas à Tomada de Controle de Companhias - São Paulo: Quartier Latin, 2011. p. 184-185. 


\section{CAPÍTULO 4 - OS MECANISMOS DE PROTEÇÃO NOS ESTADOS UNIDOS}

Nos Estados Unidos, alguns estados possuem legislação e jurisdição própria para regular e julgar matérias que envolvam aquisições hostis de controle e mecanismos de proteção. ${ }^{197}$

A título de exemplo, os estados de Delaware e Nova Iorque vedam qualquer fusão, ou operações similares, entre companhia-alvo e o ofertante, por um período determinado de tempo após o ofertante ter adquirido certo percentual de ações, a não ser que a aquisição tenha sido previamente aprovada pelo conselho antes de atingido aquele limite. ${ }^{198}$ Isso protege os acionistas contra ofertas hostis coercitivas e contra as chamadas two tier takeovers.

A legislação do estado de Delaware, particularmente importante em matéria societária, determina que, por um período de três anos após a aquisição de significativa parcela de ações votantes, o adquirente não poderá estabelecer com a companhia-alvo qualquer operação de fusão ou similares, ressalvados alguns casos previstos na Delaware General $\begin{array}{llll}\text { Corporation Law } & \$ & 203(a) .{ }^{199}\end{array}$

197 “[...] When the Williams Act was passed, only one state had a statute regulating attempted takeovers or ordinary business corporations. By the time of the Supreme Court's 1982 decision in MITE [...], about 37 states had adopted statutes regulating takeovers. (CLARK, Robert Charles. Corporate Law. Boston/Toronto: Little, Brown and Company, 1986. p. 568)

198 TOLEDO, Paulo Fernando Campos Salles de. Poison pill: Modismo ou Solução? In: CASTRO, Rodrigo R. Monteiro de; ARAGÃO, Leandro Santos de (coord.). Direito Societário - Desafios Atuais. São Paulo: Quartier Latin, 2009. p. 162-163.

$199 \S 203$ Business combinations with interested stockholders. (a) Notwithstanding any other provisions of this chapter, a corporation shall not engage in any business combination with any interested stockholder for a period of 3 years following the time that such stockholder became an interested stockholder, unless: (1) Prior to such time the board of directors of the corporation approved either the business combination or the transaction which resulted in the stockholder becoming an interested stockholder; (2) Upon consummation of the transaction which resulted in the stockholder becoming an interested stockholder, the interested stockholder owned at least $85 \%$ of the voting stock of the corporation outstanding at the time the transaction commenced, excluding for purposes of determining the voting stock outstanding (but not the outstanding voting stock owned by the interested stockholder) those shares owned (i) by persons who are directors and also officers and (ii) employee stock plans in which employee participants do not have the right to determine confidentially whether shares held subject to the plan will be tendered in a tender or exchange offer; or (3) At or subsequent to such time the business combination is approved by the board of directors and authorized at an annual or special meeting of stockholders, and not by written consent, by the affirmative vote of at least $662 / 3 \%$ of the outstanding voting stock which is not owned by the interested stockholder. 
O estado de Delaware merece especial atenção, por sua reconhecida expertise e reputação em matéria de direito societário.

\section{1 - A importância do estado de Delaware}

Conforme o esclarecedor artigo "Why Businesses Choose Delaware"200, questiona-se com muita frequência o seguinte: Por que Delaware? Por que um estado tão pequeno ocupa uma posição tão importante? Há uma série de respostas, mas muitas delas não refletem o que as pessoas geralmente pensam. Por exemplo, Delaware não é um paraíso fiscal, e também não é o estado mais barato para se constituir empresas, ao contrário do que muitos acreditam.

Delaware não é mais amiga de administradores, nem mais amiga de acionistas. O seu objetivo é disponibilizar uma regulação eficiente para o desenvolvimento de uma relação negocial ética e rentável, tanto para os administradores quanto para os investidores.

Conforme o referido artigo, o estado de Delaware foi pioneiro na formação de empresas desde o começo dos anos 90. Mais de $60 \%$ das companhias listadas na Fortune 500 encontram-se no estado. No entanto, é importante destacar que a organização em Delaware não é exclusiva de empresas norte-americanas. Diversas companhias ao redor do mundo podem extrair vantagens dos benefícios proporcionados pelo estado.

Ressalte-se que muitos fatores foram responsáveis pela dominância de Delaware na constituição de empresas.

Em primeiro lugar, a sua lei, o Delaware General Corporation Law ("DGCL"), que foi criada por especialistas em direito societário, e é revisada anualmente para assegurar sua atualização conforme as tendências e discussões atuais.

\footnotetext{
${ }^{200}$ Ressalte-se que, nessa seção, parte do conteúdo do artigo foi traduzido de forma livre do inglês para o português. (Why Businesses Choose Delaware. Disponível em: <http://corplaw.delaware.gov/eng/why_delaware.shtml>. Acesso em: 23/04/2016).
} 
O DGCL é uma legislação aberta. Ao mesmo tempo que inclui alguns requisitos obrigatórios e necessários à proteção dos investidores, permite flexibilidade para as companhias conduzirem seus negócios.

Em segundo lugar, tão importante quanto a lei são os tribunais que a interpretam. Delaware é reconhecida por seu sistema judicial e pela expertise e imparcialidade dos juízes que decidem os casos envolvendo matérias societárias. A Corte de Chancelaria de Delaware (Delaware Court of Chancery) é um juízo especial de equidade com jurisdição específica sobre disputas societárias. A corte conta com apenas juristas de alta expertise, selecionados por meio de um processo bipartidário e meritocrático.

Os casos julgados pela Corte de Chancelaria são passíveis de recurso diretamente à Suprema Corte de Delaware (Delaware Supreme Court), tendo esta a última palavra com relação ao direito do estado. A Suprema Corte tem cinco juízes, cada um com experiência considerável na aplicação da lei societária de Delaware.

Em terceiro lugar, a Corte de Chancelaria e a Suprema Corte tem uma tradição histórica de emitir pareceres fundamentados que dão suporte às suas decisões, de modo a permitir a criação de uma jurisprudência sólida. A jurisprudência consolidada constitui um guia detalhado e importante para as companhias e seus conselheiros.

Um dos conceitos-chave incorporado na jurisprudência de Delaware é o da "business judgment rule"201 que, como se verá adiante, é o reconhecimento judicial de que juízes do direito não estão aptos para questionar as decisões tomadas de boa-fé e com diligência por administradores, ainda que posteriormente essas decisões venham a

\footnotetext{
${ }^{201}$ Conforme o Black's Law Dictionary sintetiza, business judgment rule, basicamente, significa: "The presumption that in making business decisions not involving direct self-interest or selfdealing, corporate directors act on an informed basis, in good faith, and in the honest belief that their actions are in the corporation's best interest. - The rule shields directors and officers from liability for unprofitable or harmful corporate transactions were made in good faith, with due care, and within the directors' or officers' authority" (GARNER, Bryan A. Black's Law Dictionary. 3a edição. Thomson/West, 2006).
} 
apresentar um resultado negativo. Juntamente com a business judgment rule, a jurisprudência proporciona orientações aos administradores para o exercício de seus deveres fiduciários de lealdade e diligência.

Em quarto lugar, a tradição legal. Delaware tem um amplo apoio de advogados experts na lei societária do estado. Esses profissionais também auxiliam os legisladores na contínua revisão da legislação societária e, anualmente, propõem mudanças para manter a lei de Delaware atualizada.

Em quinto lugar, a secretaria do estado de Delaware, a Division of Corporations of the Delaware Secretary of State's Office existe para fornecer às companhias e seus conselheiros um serviço rápido e eficiente. A Division of Corporations fica aberta 15 horas por dia para absorver a demanda de registros que provém de todas as partes do mundo. A Division of Corporations oferece serviços especializados e rápidos (incluindo serviços de uma, duas e 24 horas) para matérias urgentes e com prazo de tempo determinado.

\subsection{1 - A business judgment rule como salvaguarda dos administradores}

Conforme o artigo The Delaware Way: Deference to the Business Judgment of Directors Who Act Loyally and Carefully ${ }^{202}$, a principal diretiva do Delaware General Corporation Law encontra-se no artigo 141 (a) ${ }^{203}$. Esse dispositivo disciplina que os negócios e atividades de todas as companhias registradas no estado de Delaware sejam administrados por ou sob a direção do conselho de administração da companhia. No cumprimento

\footnotetext{
202 The Delaware Way: Deference to the Business Judgment of Directors Who Act Loyally and Carefully. Disponível em: <http://corplaw.delaware.gov/eng/delaware_way.shtml>. Acesso em: 08/02/2016.

$203 \S 141$ Board of directors; powers; number, qualifications, terms and quorum; committees; classes of directors; nonstock corporations; reliance upon books; action without meeting; removal. (a) The business and affairs of every corporation organized under this chapter shall be managed by or under the direction of a board of directors, except as may be otherwise provided in this chapter or in its certificate of incorporation. If any such provision is made in the certificate of incorporation, the powers and duties conferred or imposed upon the board of directors by this chapter shall be exercised or performed to such extent and by such person or persons as shall be provided in the certificate of incorporation.
} 
de suas funções, os administradores detêm deveres fiduciários de lealdade e cautela com relação à companhia e seus acionistas.

Em relação à business judgment rule, mesmo que algumas operações, por sua dimensão, exijam o consentimento de acionistas, o conselho de administração, em geral, detém o poder-dever de tomar decisões relacionadas aos negócios e atividades da companhia.

Estas decisões referem-se tanto para se estabelecer planejamentos e estratégias, como também a contratação e desligamento de diretores executivos. A lei de Delaware oferece aos administradores incumbidos de tomar estas decisões uma gama de presunções - conhecida como a regra do business judgment rule - que, tomando por consideração o fato da maioria dos administradores não possuir interesses conflitantes com relação à decisão, a sua decisão não será adiante questionada pelo judiciário se tomada com o devido cuidado e boa-fé.

A business judgment rule, regra aplicada até mesmo quando a decisão tomada é posteriormente classificada como imprudente, é a peça central do direito societário de Delaware.

Sobre a regra, afirma CLARK:

In contrast to this worrisome doctrine, the mere mention of the business judgment rule brings smiles of relief to corporate directors. In a sense, the business judgment rule is just a corollary of the usual statutory provision that it is the directors who shall manage the corporation. The rule is simply that the business judgment of the directors will not be challenged or overturned by courts or shareholders, and the directors will not be held liable for the consequences of their exercise of business judgment - even for judgments that appear to have been clear mistakes - unless certain exceptions apply. Put another way, the rule is "a presumption that in making a business decision, the directors of a corporation acted on an informed basis in good faith and in the honest belief that the action was taken in the best interests of the company. ${ }^{204}$

O autor ainda analisa a regra quando aplicada no âmbito das aquisições de controle e mecanismos de proteção:

Before examining the emerging case law, it is useful to get a sense of what the possibilities are. There are at least five types of rules that could be adopted to govern the behavior of target company directors and officers who cause their

${ }^{204}$ CLARK, Robert Charles. Corporate Law. Boston/Toronto: Little, Brown and Company, 1986. p. $123-124$. 
company to take defensive measures against a takeover attempt. [...] A fifth rule is the business judgment rule: the decision to commit corporate resources to a takeover defense is a matter within the normal business discretion of the target's directors and officers, and could not be successfully challenged unless the plaintiff could prove some serious failure on the defendants' part - such as gross negligence or palpable overreaching. Since target managers usually go throught the forms of carefulness - they hire expensive counsel and investment bankers, hold many meetings, and leave a justificatory paper trail - and since they can and do allege the corporate good as a basis for their defensive maneuvers, this rule makes it impossible to attack any but the most outrageous defensive maneuvers. ${ }^{205}$

\subsection{2 - Casos da Suprema Corte de Delaware}

\subsubsection{1 - Unocal Corp. v. Mesa Petroleum Co.}

No caso Unocal Corp. v. Mesa Petroleum Co. ${ }^{206}$, apreciado pela Suprema Corte de Delaware, analisou-se as medidas de defesa empreendidas pelo Conselho de Administração da Unocal Corporation ("Unocal") contra a tentativa de aquisição de controle hostil da Unocal pela Mesa Petroleum Co. (“Mesa Petroleum”).

Nesse caso, a Suprema Corte de Delaware também analisou a validade de uma recompra de ações que excluiu o acionista que estava realizando uma oferta hostil para a tomada de controle.

O caso teve origem após a Mesa Petroleum, acionista detentora de aproximadamente $13 \%$ das ações da Unocal, realizar uma oferta pública para aquisição de, aproximadamente, $37 \%$ das ações em circulação da Unocal, pelo preço de US\$ 54,00 por ação. Após a referida aquisição, as ações remanescentes seriam retiradas de circulação, mediante permuta de valores mobiliários realizada pela Mesa Petroleum.

A Mesa Petroleum, ao observar uma determinação judicial, emitiu uma declaração ${ }^{207}$, destinada aos acionistas da Unocal, que divulgava as

\footnotetext{
205 Ibid. p. 579-582.

${ }^{206}$ Unocal Corp. v. Mesa Petroleum Co. (493 A.2d 946, Delaware, 1985, Rel. Moore).

207 "Mesa's May 3, 1985 supplement to its proxy statement states:

(i) following the Offer, the Purchasers would seek to effect a merger of Unocal and Mesa Eastern or an affiliate of Mesa Eastern (the "Merger") in which the remaining Shares would be acquired for a combination of subordinated debt securities and preferred stock; (ii) the securities to be received by Unocal shareholders in the Merger would be subordinated to $\$ 2,400$ million of debt securities of Mesa Eastern, indebtedness incurred to refinance up to $\$ 1,000$ million of bank debt which was incurred by affiliates of Mesa Partners II to purchase Shares and to pay related interest
} 
características dos valores mobiliários que iriam substituir as ações remanescentes na segunda etapa da transação proposta. Os valores mobiliários, em questão, seriam altamente subordinados, e são conhecidos pelo mercado sob o jargão de "junk bonds".

Diante disso, os administradores da Unocal se reuniram algumas vezes para tratar sobre a referida oferta. A primeira reunião, em especial, durou nove horas e meia, e treze conselheiros estavam presentes. Advogados fizeram apresentações detalhadas sobre as obrigações do Conselho de Administração à luz da legislação societária federal e a legislação societária do estado de Delaware. Nessa reunião, o Conselho também assistiu a uma apresentação feita por Peter Sachs, em nome da Goldman Sachs \& Co. ("Goldman Sachs") e Dillon, Read \& Co. ("Dillon Read"), ocasião em que discutiram as razões pelas quais entendiam que a proposta de Mesa Petroleum era totalmente inadequada.

Os administradores, em outra reunião, entenderam estar diante de uma oferta coercitiva (two tier tender offer) e, por isso, rejeitaram, por unanimidade, a oferta proposta sob o fundamento de que a mesma seria inadequada. ${ }^{208}$ Por fim, o Conselho de Administração decidiu pela adoção de estratégias de defesa.

Baseando-se nas orientações de seus assessores financeiros e em suas próprias deliberações, como resposta, os administradores decidiram realizar uma oferta pública de recompra de $49 \%$ das ações em circulação, pelo valor de US\$72,00, a ser quitado por títulos de dívida. Sendo que, excluiu-se da

and expenses and all then-existing debt of Unocal; (iii) the corporation surviving the Merger would be responsible for the payment of all securities of Mesa Eastern (including any such securities issued pursuant to the Merger) and the indebtedness referred to in item (ii) above, and such securities and indebtedness would be repaid out of funds generated by the operations of Unocal; (iv) the indebtedness incurred in the Offer and the Merger would result in Unocal being much more highly leveraged, and the capitalization of the corporation surviving the Merger would differ significantly from that of Unocal at present; and (v) in their analyses of cash flows provided by operations of Unocal which would be available to service and repay securities and other obligations of the corporation surviving the Merger, the Purchasers assumed that the capital expenditures and expenditures for exploration of such corporation would be significantly reduced." (Unocal Corp. v. Mesa Petroleum Co. 493 A.2d 946, Delaware, 1985, Rel. Moore. Nota de Rodapé $\left.\mathrm{n}^{\circ} 3\right)$. 
recompra em questão as ações detidas ou recém adquiridas pela Mesa Petroleum.

A polêmica suscitada no caso diz respeito ao fato de a Unocal realizar a aquisição de suas próprias ações de forma seletiva, excluindo a Mesa Petroleum na qualidade de acionista. Discutiu-se aqui se os administradores da Unocal não estariam violando seus deveres fiduciários ao tratarem de forma distinta os acionistas em relação à oferta realizada. ${ }^{209}$

Basicamente, a Suprema Corte de Delaware entendeu e definiu o seguinte:

HN5 The business judgment rule, including the standards by which director conduct is judged, is applicable in the context of a takeover. The business judgment rule is a presumption that in making a business decision the directors of a corporation acted on an informed basis, in good faith and in the honest belief that the action taken was in the best interests of the company. A hallmark of the business judgment rule is that a court will not substitute its judgment for that of the board if the latter's decision can be attributed to any rational business purpose. [...] HN10 If a defensive measure is to come within the ambit of the business judgment rule, it must be reasonable in relation to the threat posed. This entails an analysis by the directors of the nature of the takeover bid and its effect on the corporate enterprise. [...] Further, the selective stock repurchase plan chosen by Unocal is reasonable in relation to the threat that the board rationally and reasonably believed was posed by Mesa's inadequate and coercive two-tier tender offer. Under those circumstances the board's action is entitled to be measured by the standards of the business judgment rule. Thus, HN13 unless it is shown by a preponderance of the evidence that the directors' decisions were primarily based on perpetuating [**34] themselves in office, or some other breach of fiduciary duty such as fraud, overreaching, lack of good faith, or being uninformed, a Court will not substitute its judgment for that of the board. ${ }^{210}$

Em outras palavras, a Suprema Corte de Delaware entendeu que (i) estava dentro dos poderes da administração a) opor-se contra a oferta pública para aquisição de controle da Mesa Petroleum; e b) adotar uma permuta de ações seletiva feita de boa-fé e com uma investigação razoável de acordo com o dever de proteger os negócios da companhia; (ii) o plano de recompra de ações foi razoável/proporcional em relação à ameaça percebida; e (iii) a referida recompra tinha direito a ser medida nos

\footnotetext{
${ }^{208}$ NASCIMENTO, João Pedro Barroso do. Medidas Defensivas à Tomada de Controle de Companhias. São Paulo: Quartier Latin, 2011. p. 207.

209 Ibid. p. 207.

${ }^{210}$ Unocal Corp. v. Mesa Petroleum Co. (493 A.2d 946, Delaware, 1985, Rel. Moore).
} 
parâmetros da business judgment rule. Como consequência, a recompra empreendida pela Unocal foi validada.

\subsubsection{2 - Moran v. Household International}

No caso Moran v. Household International ${ }^{211}$, a Suprema Corte de Delaware analisou a validade do mecanismo de defesa contra a tomada hostil de controle conhecido por Preferred Share Purchase Rights Plan (“Rights Plan”), semelhante à terceira versão do plano de poison pill já exposta neste trabalho. A validade do mecanismo chamava a atenção de todos à época em que o caso foi submetido à Suprema Corte de Delaware.

O Conselho de Administração da Household International ("Household") adotou o Rights Plan por votação de 14 a 2. Basicamente, o plano previa que os acionistas ordinários fariam jus a um direito por cada ação ordinária, sob a condição de ocorrer um evento que disparasse o gatilho do plano. Dois eventos poderiam ativar esses direitos. O primeiro se verificaria com o anúncio de uma oferta pública para a aquisição de $30 \%$ das ações de emissão da Household. O segundo seria a aquisição de $20 \%$ das ações de emissão da Household por uma única pessoa ou grupo.

Se o anúncio de uma oferta pública para a aquisição de $30 \%$ das ações da Household fosse feito, os direitos atribuídos por tal plano seriam emitidos e seriam imediatamente exercíveis para a aquisição 1/100 das novas ações preferenciais pelo valor de US\$100,00, e seriam resgatáveis pelo Conselho de Administração pelo valor de US\$ 50,00 para cada direito atribuído. Se $20 \%$ das ações da Household fossem adquiridas por alguém, os direitos seriam emitidos, tornariam-se não resgatáveis, e seriam exercíveis para a aquisição de 1/100 das ações preferencias. Se o direito atribuído por tal plano não fosse exercido e, depois disso, uma incorporação ou fusão ocorresse, o titular do direito poderia exercer para cada direito a compra das ações ordinárias cujo valor na oferta seria de US\$200,00, pelo

\footnotetext{
${ }^{211}$ Moran v. Household Int'1 (500 A.2d 1346, Delaware, 1985, Rel. MecNeilly).
} 
valor de US\$ 100,00. Essa disposição de flip-over do Rights Plan era a grande controvérsia do plano.

A Household era uma companhia holding diversificada com subsidiárias que atuavam no mercado de serviços financeiros, transporte e merchandising. A HFC, a National Car Rental e Vons Grocery eram três de suas subsidiárias integrais.

É importante notar que a Household não adotou o Rights Plan no âmbito de uma batalha com corporate raiders, mas apenas como um mecanismo preventivo para protege-la de futuras investidas.

Entretanto, Moran, um dos conselheiros da Household e também presidente da Dyson-Kissner-Moran Corporation (“D-K-M”), e um dos maiores acionistas da Household, começou a tratar de um possível leveraged buy-out ${ }^{212 \_213}$ da Household pela D-K-M.

Os estudos financeiros realizados pela D-K-M concluíram que as ações da Household estavam significativamente subvalorizadas em relação ao valor do "break-up" da companhia.

Preocupada com a vulnerabilidade da Household em face de raiders à luz do ambiente de tomada de controle vivenciado à época, a Household contratou os serviços do escritório Wachtell, Lipton, Rosen and Katz ("Wachtell, Lipton”) e da Goldman Sachs \& Co ("Goldman Sachs”) para formular uma apresentação ao Conselho de Administração da Household.

Em uma reunião, o advogado Martin Lipton, representante do Wachtell, Lipton, explicou ao Conselho de Administração que a recomendação do plano em questão feita por ele foi baseada no entendimento de que havia uma preocupação com a frequência crescente de

\footnotetext{
${ }^{212}$ Conforme o Black's Law Dictionary, buyout significa "The purchase of all or a controlling percentage of the assets or shares of a business". (GARNER, Bryan A. Black's Law Dictionary. 3a edição. Thomson/West, 2006. p. 84.)

${ }^{213}$ Conforme o Black's Law Dictionary, leveraged buyout, por sua vez, significa "The purchase of a publicly held corporation's outstanding stock by its management or outside investors, financed mainly with funds borrowed from investment bankers or brokers and usu. secured by the corporation's assets" (GARNER, Bryan A. Black's Law Dictionary. 3a edição. Thomson/West, 2006. p. 84).
} 
"bust-up takeovers" $" 14$, a crescente atividade de takeover na indústria de serviços financeiros, tal como a tentativa da Leucadia para tomar o controle da Arco, bem como o possível efeito adverso que esse tipo de atividade poderia gerar aos empregados e outros que estivessem preocupados com o sucesso da continuidade das operações da Household, ainda que na ausência real de uma "bust-up takeover". Diante deste contexto fático, o plano foi aprovado.

O caso teve origem com a ação ajuizada por Moran em conjunto com a D-K-M, companhia da qual era presidente.

Sendo assim, a Suprema Corte de Delaware, analisou, primeiramente, a adoção do Rights Plan à luz do princípio da business judgment rule. A decisão se deu, basicamente, nos seguintes termos:

This case is distinguishable from the ones cited, since here we have a defensive mechanism adopted to ward off possible future advances and not a mechanism adopted in reaction to a specific threat. [...] Of HN3 course, the business judgment rule can only sustain corporate decision making or transactions that are within the power or authority of the Board. Therefore, before the business judgment rule can be applied it must be determined whether the Directors were authorized to adopt the Rights Plan. [...] HN4 Our corporate law is not static. It must grow and develop in response to, indeed in anticipation of, evolving concepts and needs. Merely because the General Corporation Law is silent as to a specific matter does not mean that it is prohibited. [...] The fact that the rights here have as their purpose the prevention of coercive two-tier tender offers does not invalidate them. [...] Furthermore, as we explain infra, we do not view the Rights Plan as much of an impediment on the tender offer process. [...] [**20] Having concluded that sufficient authority for the Rights Plan exists in 8 Del.C. $\S$ 157, we note HN8 the inherent powers of the Board conferred by 8 Del.C. $\S$ 141(a), 11 concerning the management of the corporation's "business and affairs" (emphasis added), also provides the Board additional authority upon which to enact the Rights Plan. Unocal, 493 A.2d at 953. [...] We conclude that the Rights Plan does not prevent stockholders from receiving tender offers, and that the change of Household's structure was less than that which results from the implementation of other defensive mechanisms upheld by various courts. [...] When the Household Board of Directors is faced with a tender offer and a request to redeem the Rights, they will not be able to arbitrarily reject the offer. They will be held to the same fiduciary standards any other board of directors would be held to in originally approving the Rights Plan. See Unocol, 493 A.2d at 954-55, 958..$^{215}$

\footnotetext{
214 "'bust-up" takeover generally refers to a situation in which one seeks to finance an acquisition by selling off pieces of the acquired company (Moran v. Household Int'l. 500 A.2d 1346, Delaware, 1985, Rel. MecNeilly. Nota de rodapé $\left.{ }^{\circ} 4\right)$.

${ }^{215}$ Moran v. Household Int'l (500 A.2d 1346, Delaware, 1985, Rel. MecNeilly).
} 
Com relação à aplicabilidade da proteção da business judgment rule, a Suprema Corte entendeu:

HN11 when the business judgment rule applies to adoption of a defensive mechanism, the initial burden will lie with the directors. The "directors must show that they had reasonable grounds for believing that a danger to corporate policy and effectiveness existed. . . They satisfy that burden 'by showing good faith and reasonable investigation. ...'" Unocal, 493 A.2d at 955 (citing Cheff v. Mathes, 199 A.2d at 554-55). In addition, the directors must show that the defensive mechanism was "reasonable in relation to the threat posed." Unocal, 493 A.2d at 955. Moreover, that proof is materially enhanced, as we noted in Unocal, where, as here, a majority of the board favoring the proposal consisted of outside independent directors who [**28] have acted in accordance with the foregoing standards. Unocal, 493 A.2d at 955; Aronson, 473 A.2d at 815. Then, the burden shifts back to the plaintiffs who have the ultimate burden of persuasion to show a breach of the directors' fiduciary duties. Unocal, 493 A.2d at 958. [...] HN12 To determine whether a business judgment reached by a board of directors was an informed one, we determine whether the directors were grossly negligent. Smith v. Van Gorkom, Del. Supr., 488 A.2d 858, 873 (1985). Upon a review of this record, we conclude the Directors were not grossly negligent. The information supplied to the Board on August 14 provided the essentials of the Plan. The Directors were given beforehand a notebook which included a three-page summary of the Plan along with articles on the current takeover environment. The extended discussion between the Board and representatives of Wachtell, Lipton and Goldman, Sachs before approval of the Plan reflected a full and candid evaluation of the Plan. Moran's expression of his views [**30] at the meeting served to place before the Board a knowledgeable critique of the Plan. The factual happenings here are clearly distinguishable from the actions of the directors of Trans Union Corporation who displayed gross negligence in approving a cash-out merger. Id. [...] In addition, to meet their burden, the Directors must show that the defensive [*1357] mechanism was "reasonable in relation to the threat posed". The record reflects a concern on the part of the Directors over the increasing frequency in the financial services industry of "boot-strap" and "bust-up" takeovers. The Directors were also concerned that such takeovers may take the form of two-tier offers. In addition, on August 14, the Household Board was aware of Moran's overture on behalf of D-K-M. In sum, the Directors reasonably believed Household was vulnerable to coercive acquisition techniques and adopted a reasonable defensive mechanism to protect itself. [...] In conclusion, the Household Directors receive the benefit of the business judgment rule in their adoption of the Rights Plan. ${ }^{216}$

Em outras palavras, (i) havia autoridade suficiente para a adoção do plano; (ii) tal plano não impedia os acionistas de receberem ofertas, e a mudança da estrutura da companhia com o plano seria menor do que se fossem implementados outros mecanismos de defesa permitidos à época; (iii) o efeito do plano para eventuais batalhas por procurações seria mínimo; (iv) os conselheiros se informaram sobre o plano e o adotaram na crença de

\footnotetext{
${ }^{216}$ Moran v. Household Int'l (500 A.2d 1346, Delaware, 1985, Rel. MecNeilly).
} 
boa-fé de que era necessário à proteção da companhia; e (v) o plano era razoável/proporcional à ameaça contra a qual era oposto. Sendo assim, os conselheiros teriam direito a receberem o benefício proporcionado pela business judgment rule.

A Suprema Corte de Delaware, portanto, entendeu que a adoção do plano (i) estava dentro dos poderes dos conselheiros; e (ii) foi um mecanismo de defesa proporcional adotado na crença de boa-fé de que a medida era necessária para proteger a companhia contra técnicas de aquisição coercitivas. Como consequência, a adoção do plano de poison pill foi validada.

\subsubsection{3 - Revlon, Inc. v. MacAndrews and Forbes Holdings, Inc.}

No caso Revlon, Inc. v. MacAndrews and Forbes Holdings, Inc. ${ }^{217}$, a Suprema Corte de Delaware analisou algumas operações formuladas para impedir os esforços de Pentry Pride, Inc. ("Pentry Pride") em adquirir a Revlon, Inc. ("Revlon”). A MacAndrews \& Forbes Holdings, Inc. era o acionista controlador da Pantry Pride.

Nesse caso, discutiu-se as medidas adotadas pela administração da Revlon ao buscar um cavaleiro branco (white knight), a Forstmann Little \& Co. (“Forstmann"), para fazer concorrência na disputa para a aquisição do controle.

Havia no caso uma opção garantida à Forstmann para a compra de determinados ativos da Revlon (the lock-up option) ${ }^{218}$, onde havia uma

\footnotetext{
${ }^{217}$ Revlon Inc. v. Macandrews \& Forbes Holdings, Inc. (506 A.2d 173, Delaware, 1986, Rel. Moore).

${ }^{218}$ Para CLARK, "a fourth kind of post-offer tactic is the lockup. Suppose Targg, the target company, has a valuable asset, such as a remarkably productive oil field, which is an important or critical attribute of Targg in the eyes of potential acquirers, but which does not constitute 'substantially all the assets' of the target within the meaning of the relevant corporation statute. Under the typical corporation statute, the board of directors is therefore able, without seeking shareholder approval, to sell the asset or grant an option to buy it. Omen, a hostile bidder, makes a tender offer to buy all of Targg's stock at $\$ 50$ per share. Targg's managers solicit Gunn, a white knight that implicitly promises to treat them better after a takeover. Gunn makes an offer at $\$ 55$, which Omen quickly matches. In order to make sure that Gunn wins the bidding war, Targg's directors vote to grant Gunn, for a fixed consideration, an option to buy the oil field for $\$ 100$ million. Thereafter, Gunn has a crushing advantage. If Omen were to raise its price high enough say, to $\$ 100$ - to win the bidding contest, Gunn would still be able to buy the oil field at the same fixed price. Omen could find that it had paid far too much for what was left of Targg. This would
} 
promessa da Revlon de negociar exclusivamente com a Forstmann diante de uma tomada de controle (the no shop provision), e o pagamento de US\$ 25 milhões de taxa de cancelamento para a Forstmann, caso a transação fosse desfeita.

Apenas para delinear os fatos, Ronald O. Perelman, presidente do Conselho de Administração e CEO da Pantry Pride, encontrou-se com Michel C. Bergerac da Revlon, para discutir uma aquisição amigável da Revlon pela Pentry Pride. Perelman sugeriu um preço no alcance de US\$ 40-50 por ação, mas a reunião acabou com Bergerac recusando a sugestão de Perelman, por considerá-la muito abaixo do valor intrínseco da Revlon. Todas as novas propostas subsequentes foram rejeitadas, talvez pela forte antipatia pessoal que Begerac tinha por Perelman.

Posteriormente, o Conselho de Administração da Pentry Pride autorizou Perelman a adquirir a Revlon, ou por negociação pelo preço no alcance de US\$ 42-43 por ação, ou por meio de uma oferta hostil pelo preço de US\$ 45. Com isso, Perelman se encontrou com Bergerac para apresentar essas possíveis abordagens da Pentry Pride.

Após isso, o Conselho de Administração da Revlon se reuniu especificamente para tratar sobre a oferta hostil iminente da Pentry Pride. Na reunião, Lazard Freres, o banco de investimento da Revlon, alertou os conselheiros de que o preço de US\$ 45 por ação era um valor totalmente inadequado. Felix Rohatyn e William Loomis da Lazard Freres explicaram que a estratégia financeira do Conselho de Administração da Pentry Pride para adquirir a Revlon seria feita por financiamento de "junk bonds" seguido de um "break-up" da Revlon, e da disposição de seus ativos.

Adicionalmente, o advogado da Revlon, Martin Lipton, recomendou duas medidas de defesa: (i) recompra de até 5 milhões de aproximadamente 30 milhões das suas ações em circulação; e (i) adoção de um Note Purchase Rights Plan. 
A Pentry Pride realizou duas ofertas hostis para a aquisição de controle. Em um primeiro momento, o Conselho de Administração da Revlon aconselhou os acionistas a não aderirem a oferta. A segunda oferta foi rejeitada pelos conselheiros, e a administração começou a negociar com outras partes interessadas em adquirir a Revlon.

Não obstante a isso, a Pantry Pride continuou determinada a adquirir o controle da Revlon propondo valores mais altos. Enquanto isso ocorria, as negociações da Revlon com a Forstmann começaram a produzir resultados.

No fim, os conselheiros, de forma unânime, acabaram aceitando um leveraged buyout da Revlon pela Forstmann.

A Suprema Corte de Delaware definiu, no caso, seu entendimento, basicamente, nos seguintes termos:

The original threat posed by Pantry Pride -- the break-up of the company -- had become a reality which even the directors embraced. Selective dealing to fend off a hostile but determined bidder was no longer a proper objective. Instead, obtaining the highest price for the benefit of the stockholders should have been the central theme guiding director action. Thus, the Revlon board could not make the requisite showing of good faith by preferring the noteholders and ignoring its duty of loyalty to the shareholders. The rights of the former already were fixed by contract. [...] Under such circumstances we must conclude that the merger agreement with Forstmann was unreasonable in relation to the threat posed. HN11 A lock-up is not per se illegal under Delaware law. Its use has been approved in an earlier case. Thompson v. Enstar Corp., Del. Ch., 509 A.2d 578 (1984). Such options can entice other bidders to enter a contest for control of the corporation, creating an auction for the company and maximizing shareholder profit. Current economic conditions in the takeover market are such that a "white knight" like Forstmann might only enter the bidding for the target company if it receives some form of compensation to cover the risks and costs involved. [...] It is ironic that the parties even considered a no-shop agreement when Revlon had dealt preferentially, and almost exclusively, with Forstmann throughout the contest. [...] HN13 Favoritism for a white knight to the total exclusion of a hostile bidder might be justifiable when the latter's offer adversely affects shareholder interests, but when bidders make relatively similar offers, or dissolution of the company becomes inevitable, the directors cannot fulfill their enhanced Unocal duties by playing favorites with the contending factions. Market forces must be allowed to operate freely to bring the target's shareholders the best price available for their equity. 16 Thus, as the trial court ruled, the shareholders' interests necessitated that the board remain free to negotiate in the fulfillment of that duty. [...] In conclusion, the Revlon board was confronted with a situation not uncommon in the current wave of corporate takeovers. A hostile and determined bidder sought the company at a price the board was convinced was inadequate. [**34] The initial defensive tactics worked to the benefit of the shareholders, and thus the board was able to sustain its Unocal burdens in justifying those 
measures. However, in granting an asset option lock-up to Forstmann, we must conclude that under all the circumstances the directors allowed considerations other than the maximization of shareholder profit to affect their judgment, and followed a course that ended the auction for Revlon, absent court intervention, to the ultimate detriment of its shareholders. No such defensive measure can be sustained when it represents a breach of the directors' fundamental duty of care. See Smith v. Van Gorkom, Del. Supr., 488 A.2d 858, 874 (1985). In that context the board's action is not entitled to the deference accorded it by the business judgment rule. The measures were properly enjoined. ${ }^{219}$

Basicamente, entendeu-se que os administradores da Revlon haviam atuado de forma inadequada, ao proporcionarem vantagens desiguais para a Forstmann, em detrimento da Pantry Pride. Entendeu-se que a aceitação da proposta pela administração levou em consideração não o melhor preço ofertado, mas as possíveis consequências negativas que poderiam ser geradas à Revlon na hipótese de recusa da oferta da Forstmann. Além disso, as disputas poderiam ter elevado ainda mais os valores, caso a oferta da Forstmann não tivesse sido aceita.

A Suprema Corte de Delaware entendeu, nesse caso, que os conselheiros haviam violado seus deveres fiduciários ao entrarem em tais operações com a Forstmann, dando fim às propostas concorrentes que poderiam ser mais interessantes para a companhia. Essencialmente, a violação ocorreu, porque os conselheiros fizeram concessões a um terceiro, ao invés de maximizar o preço de venda da Revlon em benefício de seus acionistas.

Sendo assim, a Suprema Corte de Delaware entendeu que (i) os conselheiros não agiram de acordo com os interesses da companhia e de seus acionistas ao darem fim às ofertas concorrentes; e (ii) que houve violação à business judgment rule. Como consequência, as operações formuladas pela Revlon para impedir os esforços de aquisição da Pentry Pride foram proibidas pela decisão judicial.

\subsubsection{4 - Paramount Communications, Inc. v. Time, Inc.}

\footnotetext{
219 Revlon Inc. v. Macandrews \& Forbes Holdings, Inc. (506 A.2d 173, Delaware, 1986, Rel. Moore).
} 
No caso Paramount Communications, Inc. v. Time, Inc. ${ }^{220}$, a Suprema Corte de Delaware analisou se deveriam ou não permitir o prosseguimento da oferta pública realizada pela Time Incorporated ("Time") para adquirir o controle da Warner Communication, Inc. ("Warner").

A Time, tendo por fim expandir seus negócios na indústria de entretenimento, convocou um comitê especial para tratar sobre novas estratégias societárias. Com isso, a Time iniciou tratativas com a Warner visando uma incorporação desta pela Time.

No entanto, durante essas negociações, uma terceira companhia, a Paramount, lançou uma oferta pública para a aquisição de controle da Time.

Tendo isso em vista, a administração da Time decidiu reverter seu plano original, e optou por realizar uma oferta pública para a aquisição de controle da Warner, de modo a tornar a Time muito menos atrativa para a Paramount, tendo em vista a expansão da companhia e o endividamento com a captação de recursos para a realização de tal oferta.

No caso, alguns acionistas questionaram a escolha da administração da Time, por entenderem que deveriam ter a possiblidade de escolha entre uma operação e outra.

Diante da controvérsia, a Suprema Corte de Delaware, definiu o seguinte:

HN1 Delaware law imposes on a corporate board of directors the duty to manage the business and affairs of the corporation. Del. Code Ann. tit. 8, § 141(a). This broad mandate includes a conferred authority to set a corporate course of action, including time frame, designed to enhance corporate profitability. Thus, the question of long-term versus short-term values is largely irrelevant because directors, generally, are obliged to charter a course for a corporation which is in its best interest without regard to a fixed investment horizon. [...] HN2 Absent a limited set of circumstances, a board of directors, while always required to act in an informed manner, is not under any per se duty to maximize shareholder value in the short term, even in the context of a takeover. [...] HN9 The obvious requisite to determining the reasonableness of a defensive action is a clear identification of the nature of the threat. This requires an evaluation of the importance of the corporate objective threatened; alternative methods of protecting that objective; impacts of the "defensive" action, and other relevant

${ }^{220}$ Paramount Communications, Inc. v. Time, Inc. (571 A.2d 1140, Delaware, 1990, Rel. Horsey). 
factors. It is not until both parts of the Unocal inquiry have been satisfied that the business judgment rule attaches to defensive actions of a board of directors. [...] HN10 Delaware law confers the management of the corporate enterprise to the stockholders' duly elected board representatives. Del. Code Ann. tit. 8, § 141(a). The fiduciary duty to manage a corporate enterprise includes the selection of a time frame for achievement of corporate goals. That duty may not be delegated to the stockholders. Directors are not obliged to abandon a deliberately conceived corporate plan for a short-term shareholder profit unless there is clearly no basis to sustain the corporate strategy. ${ }^{221}$

Em síntese, entendeu-se que a iniciativa dos administradores da Time se demonstrou coerente com a perspectiva de longo prazo da Companhia. Entendeu-se que os administradores não estavam defendendo interesses pessoais, mas sim os melhores interesses da companhia, visto que o que se visava no caso era a preservação da estratégia de longo prazo da Time. Não houve, portanto, a responsabilização dos administradores.

A Suprema Corte de Delaware entendeu que a Time respondeu à oferta concorrente de forma razoável e proporcional. Como consequência, a oferta feita pela Time para a aquisição das ações da Warner não foi impedida.

\subsubsection{5 - Paramount Communications v. Qvc Network}

No caso Paramount Communications v. Qve Network ${ }^{222}$, analisou-se as medidas defensivas adotadas para facilitar uma aliança estratégica entre a Viacom Inc. ("Viacom") e a Paramount Communications Inc. ("Paramount"), e impedir uma oferta pública hostil para a aquisição de controle realizada pela QVC Network Inc. (“QVC”).

No começo dos anos 80, a Paramount vinha estudando a possibilidade de adquirir ou incorporar outras companhias com atividades ligadas à indústria de mídia, entretenimento e comunicação. De acordo com essa estratégia de expansão inclusive, a Paramount realizou a oferta pública de aquisição da Time, Inc., mas não obteve sucesso, conforme analisado no caso anterior.

\footnotetext{
${ }^{221}$ Paramount Communications, Inc. v. Time, Inc. (571 A.2d 1140, Delaware, 1990, Rel. Horsey).

${ }^{222}$ Paramount Communications v. Qvc Network (637 A.2d 34, Delaware, 1994, Rel. Veasey).
} 
No início dos anos 90, a Paramount e a Viacom estudaram possíveis operações de combinação de negócios das duas sociedades. Em 1993, o Conselho de Administração da Paramount aprovou por unanimidade um acordo de incorporação. Nesse acordo, havia a previsão de (i) uma cláusula de exclusividade (no-shop provision), que impedia reorganizações societárias da Paramount com terceiros, a menos que esse terceiro pudesse demonstrar que a proposta não estaria associada a criação de contingências financeiras; (ii) uma opção de compra de ações (stock option agreement) concedida à Viacom, dando direitos de compra de ações correspondentes a $20 \%$ do capital social da Paramount, por valor inferior ao valor de mercado, caso a operação com a Viacom não fosse efetuada; e (iii) uma multa rescisória (termination fee provision) de US\$ 100 milhões, caso o negócio da Paramount com a Viacom não fosse concluído.

Não obstante a todas essas previsões contratuais, a QVC decidiu realizar uma oferta pública para a aquisição de controle da Paramount.

Após várias propostas realizadas pelos concorrentes na oferta, o Conselho de Administração da Paramount anunciou publicamente que recomendaria a aceitação da proposta da Viacom pelos acionistas e que continuaria rejeitando a oferta da QVC. A Paramount se baseou no precedente da Paramount $v$. Time para justificar essa decisão.

No caso, demonstrou-se que a Paramount estava equivocada, e que este caso em específico possuía características diferentes das do caso Paramount v. Time.

Sendo assim, a Suprema Corte de Delaware definiu, basicamente, o seguinte:

HN5 The consequences of a sale of control impose special obligations on the directors of a corporation. In particular, they have the obligation of acting reasonably to seek the transaction offering the best value reasonably available to the stockholders. The courts will apply enhanced scrutiny to ensure that the directors have acted reasonably. [...] HN7 In the sale of control context, the directors must focus on one primary objective--to secure the transaction offering the best value reasonably available for the stockholders--and they must exercise their fiduciary duties to further that end. [...] HN10 In determining which sale of control alternative provides the best value for the stockholders, a board of 
directors is not limited to considering only the amount of cash involved, and is not required to ignore totally its view of the future value of a strategic alliance. Instead, the entire situation should be analyzed, and the consideration being offered should be evaluated in a disciplined manner. Where stock or other noncash consideration is involved, the board should try to quantify its value, if feasible, to achieve an objective comparison of the alternatives. In addition, the board may assess a variety of practical considerations relating to each alternative including: an offer's fairness and feasibility; the proposed or actual financing for the offer, and the consequences of that financing; questions of illegality; the risk of non-consummation; the bidder's identity, prior background and other business venture experiences; and the bidder's business plans for the corporation and their effects on stockholder interests. [...] HN22 Where a corporate board has no reasonable basis upon which to judge the adequacy of a contemplated sale of control transaction, a no-shop restriction gives rise to the inference that the board seeks to forestall competing bids. The no-shop provision, like the lock-up option, while not per se illegal, is impermissible under the Unocal standards when a board's primary duty becomes that of an auctioneer responsible for selling the company to the highest bidder. [...] The realization of the best value reasonably available to the stockholders became the Paramount directors' primary obligation under these facts in light of the change of control. That obligation was not satisfied, and the Paramount Board's process was deficient. [...] Rather than seizing those opportunities, the Paramount directors chose to wall themselves off from material information which was reasonably available and to hide behind the defensive measures as a rationalization for refusing to negotiate with QVC or seeking other alternatives. Their view of the strategic alliance likewise became an empty rationalization as the opportunities for higher value for the stockholders continued to develop. ${ }^{223}$

Em outras palavras, entendeu-se que os administradores da Paramount violaram seus deveres fiduciários favorecendo a operação da Viacom, ao invés da oferta mais valiosa realizada pela QVC.

A Suprema Corte de Delaware entendeu, portanto, que os conselheiros da companhia-alvo violaram seus deveres fiduciários ao falharem em considerar de maneira adequada qual oferta seria melhor para os acionistas. As disposições de defesa não poderiam alterar esses deveres. Como consequência, a venda de controle da Paramount para a Viacom foi proibida pela decisão judicial.

\subsubsection{6 - Unitrin, Inc. v. American General Corp.}

No caso Unitrin v. American General Corp. ${ }^{224}$, analisou-se as medidas de defesa adotadas pelo Conselho de Administração da Unitrin,

\footnotetext{
${ }^{223}$ Paramount Communications v. Qvc Network (637 A.2d 34, Delaware, 1994, Rel. Veasey).

${ }^{224}$ Unitrin, Inc. v. Am. Gen. Corp. (651 A.2d 1361, Delaware, 1995, Rel. Holland).
} 
Inc. ("Unitrin") contra a oferta para aquisição de controle realizada pela American General Corporation ("American General").

Inicialmente, a American General tinha anunciado publicamente uma proposta de incorporação com a Unitrin por US\$ 2,6 bilhões pelo preço de US\$ 50-3/8 por ação, e alguns acionistas solicitaram o impedimento da Unitrin de realizar uma recompra de até 10 milhões de suas ações.

Em certo momento, James Tuerff, o presidente da American General, encontrou-se com Richard Vie, CEO da Unitrin. Tuerff avisou Vie que estava considerando adquirir outras companhias. A Unitrin aparentemente estava no topo de sua lista. Tuerff não mencionou quaisquer termos para a potencial aquisição da Unitrin. Vie replicou dizendo que a Unitrin tinha excelentes perspectivas como uma companhia independente e nunca havia considerado uma incorporação. Vie, portanto, avisou Tuerff de que a Unitrin não estava à venda.

Posteriormente, a American General enviou uma carta à Vie propondo uma operação de incorporação consensual. A oferta estava condicionada à elaboração de um acordo de incorporação e uma aprovação regulatória. O preço da oferta representava $30 \%$ de prêmio sobre o valor de mercado das ações da Unitrin. Na oferta, a American General disse que consideraria um preço mais alto, caso a Unitrin demonstrasse haver um valor adicional.

Logo após isso, o Conselho de Administração da Unitrin se reuniu para tratar sobre o assunto. Na ocasião, assistiram à apresentação de seu assessor financeiro, Morgan Stanley, que expressou a opinião de que a oferta apresentava um valor inadequado. Os advogados alertaram para o fato de que a incorporação geraria complicações de antitruste devido ao resultado de diminuição da competição no mercado em que atuavam as companhias.

Sendo assim, o Conselho de Administração da Unitrin conclui, por unanimidade, que a referida proposta de incorporação não estava de acordo 
com os interesses da companhia e de seus acionistas e, portanto, votou por sua rejeição. Com isso, Vie enviou uma carta à Tuerff, rejeitando a oferta.

Logo em seguida, a American General anunciou uma oferta hostil para a aquisição da totalidade das ações da Unitrin pelo preço de US\$ 503/8 por ação. Depois do anúncio, o mercado reagiu e houve um aumento do preço das ações da Unitrin.

O Conselho de Administração da Unitrin se reuniu depois disso, e entendeu que a oferta hostil coagia a venda da Unitrin por um preço inadequado. Tendo isso em vista, o Conselho de Administração aprovou, por unanimidade, a adoção de uma poison pill.

O Conselho se reuniu posteriormente para considerar um plano de recompra de ações da Unitrin, e acabou autorizando a recompra de até 10 milhões de ações da Companhia.

A Suprema Corte de Delaware definiu o seguinte:

HN5 The business judgment rule applies to the conduct of directors in the context of a takeover. See Pogostin v. Rice, Del. Supr., 480 A.2d 619 (1984); Aronson v. Lewis, Del. [*1373] Supr., 473 A.2d 805, 812 (1984). 10 Accord Paramount Communications, Inc. v. QVC Network, Inc., Del. Supr., 637 A.2d 34, 41-42 (1994). The business judgment rule is a "presumption that in making a business decision the directors of a corporation acted on an informed basis, in good faith and in the honest belief that the action taken was in the best interests of the company." Aronson v. Lewis, 473 A.2d at 812. 11 An application of the traditional business judgment rule places the burden on the "party challenging the [board's] decision to establish facts rebutting the presumption." Id. If the business judgment rule is not rebutted, a "court will not substitute its judgment for that ofthe board if the [board's] decision can be 'attributed to any rational business purpose.'" Unocal, 493 A.2d at 954 [**24] (citation omitted). [...]In Unocal, this Court reaffirmed HN6 "the application of the business judgment rule in the context of a hostile battle for control of a Delaware corporation where board action [**25] is taken to the exclusion of, or in limitation upon, a valid stockholder vote." Stroud v. Grace, 606 A.2d at 82. This Court has recognized that directors are often confronted with an "'inherent conflict of interest' during contests for corporate control 'because of the omnipresent specter that a board may be acting primarily in its own interests, rather than those of the corporation and its shareholders.'" Id. (quoting Unocal, 493 A.2d at 954). Consequently, in such situations, before the board is accorded the protection of the business judgment rule, and that rule's concomitant placement of the burden to rebut its presumption on the plaintiff, the board must carry its own initial two-part burden: First, a reasonableness test, which is satisfied by a demonstration that the board of directors had reasonable grounds for believing that a danger to corporate policy and effectiveness existed, and Second, a proportionality test, which is satisfied by a demonstration that the board of directors' defensive response was reasonable in relation to the threat posed. [...] HN18 "The obvious requisite to determining the 
reasonableness of a defensive action is a clear identification of the nature of the threat." Paramount Communications, Inc. v. Time, Inc., Del. Supr., 571 A.2d 1140, 1154 (1990). [**63] Courts, commentators and litigators have attempted to catalogue the threats posed by hostile tender offers. Id. at 1153 . Commentators have categorized three types of threats: (i) opportunity loss ... [where] a hostile offer might deprive target shareholders of the opportunity to select a superior alternative offered by target management [or, we would add, offered by another bidder]; (ii) structural coercion, . . . the risk that disparate treatment of nontendering shareholders might distort shareholders' tender decisions; and (iii) substantive coercion, ... . the risk that shareholders will mistakenly accept an underpriced offer because they disbelieve management's representations of intrinsic value. [...] HN26 If a defensive measure is not draconian, however, because it is not either coercive [*1388] or preclusive, the Unocal proportionality test requires the focus of enhanced judicial scrutiny to shift to "the range of reasonableness." Paramount Communications, Inc. v. QVC Network, Inc., Del. Supr., 637 A.2d 34, 45-46 (1994). Proper and proportionate defensive responses are intended and permitted to thwart perceived threats. When a corporation is not for sale, the board of directors is the defender of the metaphorical medieval corporate bastion and the protector of the corporation's shareholders. The fact that a defensive action must not be coercive or preclusive does not prevent a board from responding defensively before a bidder is at the corporate bastion's gate. [...] HN28 A limited nondiscriminatory self-tender, like some other defensive measures, may thwart a current hostile bid, but is not inherently coercive. Moreover, it does not necessarily preclude [**79] future bids or proxy contests by stockholders who decline to participate in the repurchase. Cf. AC Acquisitions Corp. v. Anderson, Clayton \& Co., Del. Ch., 519 A.2d 103 (1986) (enjoining a coercive self-tender and restructuring plan). A selective repurchase of shares in a public corporation on the market, such as Unitrin's Repurchase Program, generally does not discriminate because all shareholders can voluntarily realize the same benefit by selling. See Larry E. Ribstein, Takeover Defenses and the Corporate Contract, 78 Geo. L.J. 71, 129-31(1989). See also Michael Bradley \& Michael Rosenzweig, Defensive Stock Repurchases, 99 Harv. L. Rev. 1377 (1986). Here, there is no showing on this record that the Repurchase Program was coercive. [...] We hold that the Court of Chancery correctly determined that the Unocal standard of enhanced judicial scrutiny applied to the defensive actions of the Unitrin defendants in establishing the poison pill and implementing the Repurchase Program. The Court of Chancery's finding, that the Repurchase Program was a disproportionate defensive response, was based on faulty factual predicates, unsupported by the record. This error was exacerbated by its application of an erroneous legal standard of "necessity" to the Repurchase Program as a defensive response. ${ }^{225}$

Em outras palavras, a Suprema Corte de Delaware, entendeu que a Corte de Chancelaria havia, corretamente, entendido que o padrão Unocal deveria ser aplicado na adoção da poison pill e do plano de recompra de ações. No entanto, a Suprema Corte de Delaware entendeu que a Corte de Chancelaria determinou, erroneamente, que o programa de recompra de ações era uma medida desproporcional e, erroneamente, aplicou a norma

\footnotetext{
${ }^{225}$ Unitrin, Inc. v. Am. Gen. Corp. (651 A.2d 1361, Delaware, 1995, Rel. Holland).
} 
legal de "necessidade" para o programa de recompra como uma resposta defensiva. Como consequência, o programa de recompra de ações acabou não sendo proibido no caso. 


\section{CAPÍTULO 5 - OS MECANISMOS DE PROTEÇÃO NO BRASIL}

Diferentemente dos Estados Unidos, no Brasil por falta de um judiciário mais especializado em matéria societária, o tema sobre aquisição hostil de controle e medidas de proteção, na prática, fica mais a cabo da Comissão de Valores Mobiliários (CVM) e das entidades auto-reguladoras do mercado de capitais, que detêm mais expertise para julgar e regular essas matérias.

\section{1 - A Comissão de Valores Mobiliários (CVM)}

Antes de abordar os mecanismos de proteção no âmbito da CVM, faz-se necessária a introdução da autarquia. A CVM é uma entidade autárquica, em regime especial, vinculada ao Ministério da Fazenda, criada pela Lei $\mathrm{n}^{\mathrm{o}}$ 6.385/76, com a finalidade de disciplinar, fiscalizar e desenvolver o mercado de capitais brasileiro. ${ }^{226}$

\section{Segundo PINHEIRO DOS SANTOS:}

O fundamento constitucional do poder normativo da CVM está hoje positivado no art. 174 da $\mathrm{CF} / 88^{227}$. A base legal e geral daquele poder está no inciso I do artigo $8^{\circ}$ da Lei n. 6.385 , de 7 de dezembro de $1976^{228}$, que fixa a competência da CVM para regulamentar matérias expressamente previstas na própria Lei $\mathrm{n}$. 6.385/76 e na Lei Societária (Lei n. 6.404/76).

Especificamente quanto à atuação sancionadora do órgão regulador do mercado mobiliário, a Lei n. 6.385/76 estabelece, nos dias atuais, que o processo administrativo destinado a apurar 'atos ilegais e práticas não equitativas de administradores, membros do conselho fiscal e acionistas de companhias abertas,

\footnotetext{
226 Sobre isso ver: O que é a CVM? Disponível em: <http://www.investidor.gov.br/menu/Menu_Investidor/a_cvm/ACVM.html>. Acesso em: 09/02/2016.

227 Art. 174. Como agente normativo e regulador da atividade econômica, o Estado exercerá, na forma da lei, as funções de fiscalização, incentivo e planejamento, sendo este determinante para o setor público e indicativo para o setor privado. $\S 1^{\circ}$ A lei estabelecerá as diretrizes e bases do planejamento do desenvolvimento nacional equilibrado, o qual incorporará e compatibilizará os planos nacionais e regionais de desenvolvimento. $\S 2^{\circ}$ A lei apoiará e estimulará o cooperativismo e outras formas de associativismo. $\S 3^{\circ} \mathrm{O}$ Estado favorecerá a organização da atividade garimpeira em cooperativas, levando em conta a proteção do meio ambiente e a promoção econômico-social dos garimpeiros. $\S 4^{\circ}$ As cooperativas a que se refere o parágrafo anterior terão prioridade na autorização ou concessão para pesquisa e lavra dos recursos e jazidas de minerais garimpáveis, nas áreas onde estejam atuando, e naquelas fixadas de acordo com o art. 21, XXV, na forma da lei.

228 Art . $8^{\circ}$ Compete à Comissão de Valores Mobiliários: I - regulamentar, com observância da política definida pelo Conselho Monetário Nacional, as matérias expressamente previstas nesta Lei e na lei de sociedades por ações; [...]
} 
dos intermediários e dos demais participantes do mercado'229 observará o procedimento fixado pela CVM, a qual poderá aplicar aos autores das infrações contra o mercado de capitais as penalidades previstas no art. 11 daquele diploma legal, sem prejuízo da responsabilidade civil (no plano individual ou coletivo) ou penal. ${ }^{230}$

Sobre a configuração do poder disciplinar da CVM, afirma TAVARES GUERREIRO:

A primeira observação a ser feita é no sentido de que existe poder disciplinar conferido por lei à Comissão, configurado por sua faculdade de apurar, mediante inquérito administrativo, atos ilegais e práticas não equiitativas de administradores e acionistas de companhias abertas, dos intermediários e dos demais participantes do mercado (Lei 6.385/76, art. 9. ${ }^{\circ}, \mathrm{V}$ ). Concretiza-se a outorga desse poder com a permissão do legislador a que a CVM aplique aos autores dos referidos atos ilegais e das práticas não eqüitativas as penalidades previstas no art. 11, sem prejuízo da responsabilidade civil ou penal $[\ldots]{ }^{231}$

A autarquia tem por objetivo, basicamente: (i) estimular a formação de poupança e sua aplicação em valores mobiliários; (ii) promover a expansão e o funcionamento eficiente e regular do mercado de valores mobiliários; (iii) proteger os investidores; (iv) evitar ou coibir a prática de ilícitos no mercado de valores mobiliário; (v) assegurar o acesso público a informações sobre os valores mobiliários negociados e seus emissores; e (vi) garantir a efetividade do princípio do full and fair disclosure. ${ }^{232}$

\section{Para CHEDIAK:}

Todo o sistema de regulação do mercado de valores mobiliários se baseia na ampla e honesta divulgação de informações. Não há ordenamento que pretenda regular o mercado de valores mobiliários que fuja dessa regra. Quando a Lei 6.385 se refere a evitar fraudes ou manipulações, ou a assegurar o acesso a

\footnotetext{
${ }^{229}$ Art $9^{\circ}$ A Comissão de Valores Mobiliários, observado o disposto no $\S 20$ do art. 15, poderá: [...] V - apurar, mediante processo administrativo, atos ilegais e práticas não eqüitativas de administradores, membros do conselho fiscal e acionistas de companhias abertas, dos intermediários e dos demais participantes do mercado; (Redação dada pela Lei ${ }^{\circ} 10.303$, de 31.10.2001) VI - aplicar aos autores das infrações indicadas no inciso anterior as penalidades previstas no Art. 11, sem prejuízo da responsabilidade civil ou penal. [...] $\S 2^{\circ} \mathrm{O}$ processo, nos casos do inciso $\mathrm{V}$ deste artigo, poderá ser precedido de etapa investigativa, em que será assegurado o sigilo necessário à elucidação dos fatos ou exigido pelo interesse público, e observará o procedimento fixado pela Comissão. (Redação pelo Decreto $\mathrm{n}^{\circ}$ 3.995, de 31.10.2001)

${ }^{230}$ PINHEIRO DOS SANTOS, Alexandre. Mercado de capitais - Regime sancionador. MEDINA OSÓRIO, Fábio; SOTTO MAYOR WELLISCH, Julya. PINHEIRO DOS SANTOS, Alexandre (Coord.). Editora Saraiva, 2012. p. 183-184.

${ }^{231}$ TAVARES GUERREIRO, José Alexandre. Sobre o poder disciplinar da CVM. Revista de direito mercantil, industrial, econômico e financeiro. São Paulo: Revista dos Tribunais. v. 43. p. 64-78, jul/set, 1981.

${ }^{232}$ O mercado de valores mobiliários brasileiro / Comissão de Valores Mobiliários. 3. Ed. Rio de Janeiro: Comissão de Valores Mobiliários, 2014. p. 60-61.
} 
informações, ou ainda a assegurar a observância de práticas comerciais equitativas no mercado, já está autorizando a Comissão de Valores Mobiliários a proteger os investidores contra o "uso de informação relevante não divulgada no mercado de valores mobiliários" (grifos do autor). ${ }^{233}$

O modelo de regulação do mercado de capitais brasileiro foi inspirado no modelo norte-americano. A criação da CVM se baseou na entidade reguladora Securities and Exchange Commission (SEC).

Conforme ensina DUBEUX:

O modelo regulatório brasileiro, espelhado no modelo norte-americano capitaneado pela SEC, baseia-se fundamentalmente na política de disclosure (ou full disclosure).

[...] A regulação da divulgação de informações visa a assegurar ao público a disponibilidade, em tempo hábil, de forma eficiente e razoável, de informações necessárias para a tomada da decisão de investir em valores mobiliários.

[...] A política de disclosure almeja, a um só tempo, a proteção do investidor e a eficiência do mercado. ${ }^{234}$

Sendo assim, a CVM é, muitas vezes, referida sob o jargão de xerife do mercado de capitais, haja vista o seu poder para supervisionar, investigar, fiscalizar e, em alguns casos, aplicar sanções aos participantes do mercado que tenham infringido as normas aplicáveis.

\subsection{1 - Decisão do colegiado de 14/04/2009 - Memorando sobre as Brazilian pills de Marcos Barbosa pinto e Otavio Yazbek}

O memorando que instigou o Parecer de Orientação CVM n ${ }^{\circ} 36$, aprovado por audiência pública, procurou identificar os principais benefícios das Brazilian pills, e demonstrar que esses benefícios não são prejudicados pela ausência de cláusulas pétreas.

Para os diretores signatários do memorando, as cláusulas pétreas exacerbam os principais custos da Brazilian pill e, por isso, o modelo jurídico de Brazilian pill sem cláusula pétrea seria o mais indicado. ${ }^{235}$

\footnotetext{
${ }^{233}$ CHEDIAK, Julian Fonseca Peña. A reforma do mercado de valores mobiliários. In: LOBO, Jorge. Reforma da Lei das Sociedades Anônimas. Rio de Janeiro: Forense, 2002. p. 539.

${ }^{234}$ DUBEUX, Julio Ramalho. A Comissão de Valores Mobiliários e os principais instrumentos regulatórios do mercado de capitais brasileiro. Porto Alegre: Sérgio Antonio Fabris Ed., 2006. p. 43-45.

${ }^{235}$ Memorando do Diretor Marcos Barbosa Pinto e Diretor Otavio Yazbek, 14.04.2008. Disponível em: <http://www.cvm.gov.br/export/sites/cvm/decisoes/anexos/0005/6491-0.pdf>. Acesso em: $13 / 02 / 2016$.
} 
Segundo eles, as Brazilian pills possuem três benefícios: (i) garantem um tratamento relativamente igualitário entre os acionistas; (ii) protegem os acionistas contra ofertas coercitivas; e (iii) aumentam o poder de barganha dos acionistas, assim como também apresentam os seguintes custos: (i) podem impedir negócios eficientes do ponto de vista econômico; e (ii) aumentam os custos de agência.

\subsection{2 - Parecer de Orientação CVM n 36/09}

Conforme a redação do Parecer de Orientação CVM n ${ }^{\circ} 36$ abaixo, a CVM optou por não aplicar penalidades, em processos administrativos sancionadores, aos acionistas que votarem pela supressão ou alteração da cláusula de proteção à dispersão acionária, ainda que não realizem a oferta pública prevista na disposição acessória (cláusula pétrea).

Nos últimos anos, os estatutos de diversas companhias passaram a conter cláusulas de proteção à dispersão acionária que obrigam o investidor que adquirir determinado percentual das ações em circulação a realizar uma oferta pública de compra das ações remanescentes.

Além disso, alguns estatutos incluem disposições acessórias a essas cláusulas, impondo um ônus substancial aos acionistas que votarem favoravelmente à supressão ou à alteração das cláusulas, qual seja, a obrigação de realizar a oferta pública anteriormente prevista no estatuto.

A CVM entende que a aplicação concreta dessas disposições acessórias não se compatibiliza com diversos princípios e normas da legislação societária em vigor, em especial os previstos nos arts. 115, 121, 122, I, e 129 da Lei n ${ }^{\circ} 6.404$, de 15 de dezembro de 1976.

Por esse motivo, a CVM não aplicará penalidades, em processos administrativos sancionadores, aos acionistas que, nos termos da legislação em vigor, votarem pela supressão ou alteração da cláusula de proteção à dispersão acionária, ainda que não realizem a oferta pública prevista na disposição acessória. ${ }^{236}$

De todo modo, por mais que a CVM tenha dado um passo adiante, manifestando-se contrariamente à aplicação das cláusulas pétreas, entendese que a Autarquia perdeu uma grande oportunidade de se manifestar com mais veemência acerca da legalidade e pertinência das Brazilian pills na realidade brasileira. ${ }^{237}{ }^{238}$

\footnotetext{
236 Parecer de Orientação CVM $\mathrm{n}^{\circ}$ 36. Disponível em: <http://www.cvm.gov.br/legislacao/pare/pare036.html>. Acesso em: 14/02/2016.

${ }^{237}$ MÜSSNICH, Francisco Antunes Maciel; LOBÃO MELO, Vitor de Britto. Análise Prática e Considerações sobre a realidade e a aplicação das medidas de proteção à tomada de controle nos estatutos sociais das companhias abertas brasileiras (Brazilian Pills). In: SILVA, Alexandre
} 


\subsection{3- Casos}

\subsubsection{1 - Mittal Steel Company N.V. e Arcelor S.A.}

No Processo Administrativo CVM RJ 2006/6904, a Mittal Steel

Company N.V. ("Mittal Steel"), em sede de recurso, contestou a manifestação conjunta das Superintendências de Registro - SRE e de Relações com Empresas - SEP que entenderam ser obrigatória a realização de oferta pública de aquisição dirigida aos acionistas minoritários da Arcelor Brasil S.A. (“Arcelor Brasil”), de acordo com o art. 10 de seu estatuto social ${ }^{239}$.

No caso, a Mittal Steel, em um primeiro momento, tinha anunciado publicamente sua intenção de realizar uma oferta hostil (não solicitada) aos acionistas da Arcelor S.A (“Arcelor”). No entanto, tendo em vista a última modificação da oferta por parte da Mittal Steel, a Arcelor divulgou um comunicado conjunto com a Mittal Steel noticiando que seus órgãos diretivos haviam chegado a um acordo, ao qual se referiram como uma "transação entre partes iguais" (merger of equals).

A Arcelor era uma companhia aberta sediada em Luxemburgo e com subsidiárias e valores mobiliários listados em diversas jurisdições (Luxemburgo, Espanha, França, Bélgica e Estados Unidos). No Brasil, a

Couto (Coord.). Direito Societário - Estudos sobre a lei de sociedades por ações. 2013. Editora Saraiva. Disponível em:

<http://www.bmalaw.com.br/arquivos/Artigos/DIREITO\%20SOCIET\%C3\%81RIO\%20\%20ESTUDOS\%20SOBRE\%20A\%20LEI\%20DE\%20SOCIEDADES\%20POR\%20A\%C3\%87\% C3\%95ES.PDF>. Acesso em: 15/05/2016. p. 271.

238 ZANINI, Carlos Klein. A Poison Pill Brasileira: Desvirtuamento, antijuridicidade $e$ ineficiência. In: ADAMEK, Marcelo Vieira Von. (Coord.). Temas de Direito Societário $e$ Empresarial Contemporâneos. São Paulo: Malheiros, 2011. p. 276-277.

${ }^{239}$ Art. 10 - A oferta pública de aquisição de ações a que se refere o Artigo $8^{\circ}$ será também exigida caso uma pessoa, que não uma Pessoa Relacionada, adquira o poder de controle da Companhia por meio de aquisição de ações de emissão do acionista controlador final da Companhia. Neste caso, a sociedade objeto da aquisição do poder de controle ficará obrigada a declarar à Bolsa de Valores de São Paulo ("Bovespa") a mudança em seu controle acionário e a sociedade adquirente deste ficará obrigada a declarar à Bovespa o valor atribuído à Companhia nessa alienação. (Voto do Diretor Relator na Decisão do Colegiado de 25/09.2006). CVM, Processo Administrativo ${ }^{\circ}$ RJ 2006-6209. Rel. Wladimir Castelo Branco Castro. Disponível em: <http://www.cvm.gov.br/export/sites/cvm/decisoes/anexos/0003/5256-0.pdf>. Acesso em: 14/02/2016. 
Arcelor era controladora da Arcelor Brasil e da Acesita S.A., duas companhias abertas listadas na Bolsa de Valores de São Paulo.

Mittal Steel, por sua vez, era uma companhia aberta sediada na Holanda com valores mobiliários listados em diversos países. A Mittal Steel era controlada pelos integrantes da família Mittal que detinham, em conjunto, por meio de participações diretas e indiretas, a totalidade das ações de classe B com voto plural equivalente, por ação dessa classe, a dez vezes os votos das ações de classe A.

No caso, os acionistas minoritários da Arcelor Brasil defendiam a necessidade de realização de OPA prevista no art. 10 do estatuto social (Brazilian pill), tendo em vista a eventual aquisição de controle direto da Arcelor pela Mittal Steel e, consequentemente, indireto da Arcelor Brasil.

Fato é que, conforme as áreas técnicas da CVM entenderam, a Mittal Steel, "adquirente do poder de controle indireto da Arcelor Brasil, tem o dever legal de cumprir a obrigação estatutariamente prevista de realização de OPA para os acionistas minoritários da Companhia”. Após manifestação da Mittal Steel, as áreas mantiveram o mesmo posicionamento.

O Diretor Relator, Wladimir Castelo Branco Castro, votou pela manutenção da decisão da área técnica, para efeitos de manifestar o entendimento de que:

(i) a CVM tem competência para exercer suas atribuições legais à luz de cláusulas estatuárias, por força dos poderes que lhe são conferidos pela Lei 6.385/76;

(ii) o art. 10 do estatuto social da Arcelor Brasil disciplina uma nova hipótese de oferta pública de aquisição obrigatória, diversa das previstas na legislação brasileira, não se aplicando, pelos fundamentos constantes deste voto, os arts. 116 e 254-A da Lei 6.404/76;

(iii) o poder de controle da Arcelor Brasil deve ser definido de acordo com a lei brasileira e o poder de controle da Arcelor, de acordo com a Lei de OPA, sendo que a aquisição do controle da Arcelor (de acordo com a Lei de OPA) transfere também o controle da Arcelor Brasil (pela Lei 6.404/76), por força da relação de dominação existente entre elas;

(iv) no art. 10 do estatuto de Arcelor Brasil, acionista controlador final, é a Arcelor e aquisição do poder de controle tem o conceito que lhe é dado pelo art. $5^{\circ}$ da Lei de OPA, de conformidade, também, com a $13^{\text {a }}$ Diretiva Européia; e

(v) pelo conceito da lei brasileira, teria havido aquisição do poder de controle da Arcelor Brasil, não se podendo examinar previamente, nem podendo considerar 
se contratada, e vinculante, para efeitos jurídicos, o compromisso assumido sob regime de melhores esforços. ${ }^{240}$

Sendo assim o Colegiado, tendo em vista o voto do Diretor Relator, acompanhado pelo presidente Marcelo Fernandes Trindade, deliberou negar provimento ao recurso interposto.

Esse precedente é importante como uma posição consolidada da CVM de exigir o cumprimento da obrigação prevista em uma Brazilian pill. ${ }^{241}$

\subsubsection{2 - Reorganização societária de Datasul S.A. e Totvs S.A.; Construtora Tenda S.A. e Gafisa S.A.; e Company S.A. e Brascan Residencial Properties S.A. (memorando para a SRE, enviado pela GER-1 em 17/09/2008, referente ao Processo RJ n²008/7849)}

Neste processo, além da análise da aplicação ou não do artigo 254-A da Lei das S.A. em casos de incorporação, analisou-se também no caso as Brazilian pills contidas nos estatutos sociais das companhias Datasul S.A. ${ }^{242}$, Construtora Tenda S.A. ${ }^{243}$ e Company S.A. ${ }^{244}$, para fins de

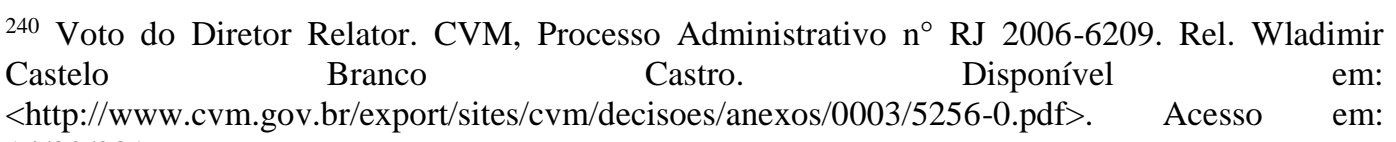
$14 / 02 / 2016$.

${ }^{241}$ Decisão do Colegiado de 25/09/2006. CVM, Processo Administrativo n ${ }^{\circ}$ RJ 2006-6209. Rel. Wladimir Castelo Branco Castro. Disponível em: <http://www.cvm.gov.br/export/sites/cvm/decisoes/anexos/0003/5256-0.pdf>. Acesso em: $14 / 02 / 2016$.

${ }^{242}$ Artigo 39 - Qualquer Acionista Adquirente, que adquira ou se torne titular de ações de emissão da Companhia, em quantidade igual ou superior a 15\% (quinze por cento) do total de ações de emissão da Companhia, deverá, no prazo máximo de 60 (sessenta) dias a contar da data de aquisição ou do evento que resultou na titularidade de ações em quantidade igual ou superior a 15\% (quinze por cento) do total de ações de emissão da Companhia, realizar uma oferta pública de aquisição da totalidade das ações de emissão da Companhia, observando-se o disposto na regulamentação aplicável da Comissão de Valores Mobiliários - CVM, inclusive quanto à necessidade ou não de registro de tal oferta pública, os regulamentos da BOVESPA e os termos deste Artigo 39, estando o Acionista Adquirente obrigado a atender as eventuais solicitações ou as exigências da CVM com base na legislação aplicável, relativas à oferta pública de aquisição, dentro dos prazos máximos prescritos na regulamentação aplicável. Parágrafo $2^{\circ}$ - O preço de aquisição na oferta pública de aquisição de cada ação de emissão da Companhia não poderá ser inferior ao maior valor entre (i) o Valor Econômico apurado em laudo de avaliação; (ii) $130 \%$ (cento e trinta por cento) do maior preço de emissão das ações em qualquer aumento de capital realizado mediante distribuição pública ocorrido no período de 12 (doze) meses que anteceder a data em que se tornar obrigatória a realização da oferta pública de aquisição nos termos deste Artigo 39, devidamente atualizado pelo IGPM/FGV até o momento do pagamento; e (iii) $130 \%$ (cento e trinta por cento) da cotação unitária média das ações de emissão da Companhia durante o período de 90 (noventa) dias anterior à realização da oferta pública de aquisição. Parágrafo $6^{\circ}-\mathrm{O}$ disposto neste Artigo não se aplica na hipótese de uma pessoa se tornar titular de ações de emissão 


\title{
caracterização ou não da necessidade de realizar oferta pública de aquisição
}

de ações.

\author{
No caso, a CVM se manifestou da seguinte forma:
}

Ao que parece, os próprios analistas indicaram que o questionamento seria do ponto de vista de governança corporativa, ainda que tecnicamente a transação estivesse correta. Buscavam os investidores um mecanismo de saída por meio das ofertas públicas, uma vez que se imaginavam blindados com as poison pills.

Nesse ponto, é importante ressaltar que as cláusulas continuavam válidas, mas as referidas companhias não foram objeto de tomadas hostis de controle.

Nos casos específicos de Tenda e Company, tais cláusulas somente serão eficazes no momento em que se configure o chamado controle difuso das companhias e, ainda assim, as operações de incorporações, seja de companhia ou de ações, são exceções ao gatilho para a realização de OPA, expressas no próprio estatuto.

da Companhia em quantidade superior a $15 \%$ (quinze por cento) do total das ações de sua emissão em decorrência (i) de sucessão legal, sob a condição de que o acionista aliene o excesso de ações em até 60 (sessenta) dias contados do evento que foi atingida tal participação; (ii) incorporação de uma outra sociedade pela Companhia; (iii) incorporação de ações de uma outra sociedade pela Companhia; ou (iv) da subscrição de ações da Companhia, realizada em uma única emissão primária, que tenha sido aprovada em Assembléia Geral de acionistas da Companhia.

${ }^{243} \mathrm{Na}$ hipótese de haver Controle Difuso, qualquer Acionista Adquirente (conforme definição abaixo), que adquira ou se torne titular de ações de emissão da Companhia, inclusive por força de usufruto que lhe assegure direitos políticos de sócio, em quantidade igual ou superior a $20 \%$ do total de ações de emissão da Companhia, excluídas para os fins deste cômputo as ações em tesouraria, deverá, no prazo de 60 dias a contar da data de aquisição ou do evento que resultou na titularidade de ações nessa quantidade, realizar ou solicitar o registro de uma oferta pública para aquisição da totalidade das ações de emissão da Companhia ("OPA"), observando-se o disposto na regulamentação aplicável da Comissão de Valores Mobiliários, os regulamentos da Bolsa de Valores de São Paulo e os termos deste Capítulo. O disposto neste Artigo não se aplica na hipótese de uma pessoa se tornar titular de ações de emissão da Companhia em quantidade superior a $20 \%$ do total das ações de sua emissão, em decorrência: da incorporação de uma outra sociedade pela Companhia ou da incorporação da Companhia por uma outra sociedade; e da incorporação de ações de uma outra sociedade pela Companhia ou da incorporação de ações da Companhia por uma outra sociedade;

244 Artigo 47 A partir da data em que o Controle da Companhia passe a ser qualificado como Controle Difuso, conforme definido no Parágrafo $3^{\circ}$ do Artigo 44 acima, qualquer Acionista Adquirente, que adquira ou se torne titular de ações de emissão da Companhia, em quantidade igual ou superior a $20 \%$ (vinte por cento) do total de ações de emissão da Companhia, deverá, no prazo máximo de 60 (sessenta) dias a contar da data de aquisição ou do evento que resultou na titularidade de ações em quantidade igual ou superior a $20 \%$ (vinte por cento) do total de ações de emissão da Companhia, realizar uma oferta pública de aquisição da totalidade das ações de emissão da Companhia, observando-se o disposto na regulamentação aplicável da Comissão de Valores Mobiliários - CVM, inclusive quanto à necessidade ou não de registro de tal oferta pública, os regulamentos da BOVESPA e os termos deste Artigo 47, estando o Acionista Adquirente obrigado a atender as eventuais solicitações ou as exigências da CVM com base na legislação aplicável, relativas à oferta pública de aquisição, dentro dos prazos máximos prescritos na regulamentação aplicável. Parágrafo Sétimo: O disposto neste Artigo não se aplica na hipótese de uma pessoa se tornar titular de ações de emissão da Companhia em quantidade superior a $20 \%$ (vinte por cento) do total das ações de sua emissão em decorrência (i) de sucessão legal, sob a condição de que o acionista aliene o excesso de ações em até 60 (sessenta) dias contados do evento que foi atingida tal participação; (ii) incorporação de uma outra sociedade pela Companhia; (iii) incorporação de ações de uma outra sociedade pela Companhia; ou (iv) da subscrição de ações da Companhia, realizada em uma única emissão primária, que tenha sido aprovada em Assembléia Geral de acionistas da Companhia. 
Já no caso de Datasul, tendo sido aprovada a incorporação de suas ações pela Makira e, subsequente migração da base acionária para a Totvs, tornando a Datasul subsidiária integral da Totvs, não há que se falar em oferta pública, por ausência de destinatários, já que todos passam a compor a base acionária da controladora, por deliberação assemblear. ${ }^{245}$

\subsubsection{3 - Processo Administrativo Sancionador CVM n RJ 2005/1443}

Embora o caso não trate especificamente de medidas de proteção, a defesa dos acusados recorreu à ampla aceitação das Brazilian pills pelo mercado e pela CVM, como forma de demonstrar a legitimidade do exercício do poder de controle e a finalidade de mantê-lo, conforme o trecho abaixo:

Além disso, os indiciados destacam que, sendo o controle uma realidade reconhecida pela Lei 6.404/76, seria legítimo o exercício de tal poder tendo por objetivo mantê-lo, da mesma forma como também é natural haver discordância com as decisões tomadas pelo controlador. Demonstraria tal legitimidade, no Brasil, a recente utilização, aplaudida pelo mercado e aceita pela CVM, de mecanismos destinados a evitar tomada hostil de controle de que são exemplos certos dispositivos estatutários (poison pills) utilizados por companhias que abriram recentemente seu capital. “(...) a precedência do interesse da maioria sobre o interesse da minoria não é ilegal. A existência de divergências entre os interesses dos acionistas não significa, necessariamente, que a maioria está agindo abusivamente, lesando a minoria. [...]". ${ }^{246}$

\section{2 - A Bolsa de Valores de São Paulo (BM\&FBovespa)}

Há no Brasil a obrigação de que bolsas de valores e entidades do mercado de balcão organizado, como órgãos auxiliares da Comissão de Valores Mobiliários, fiscalizem os respectivos membros e as operações com valores mobiliários nelas realizadas. Essa obrigação decorre da Lei $\mathrm{n}^{\circ}$ $6.385 / 76.247$

\footnotetext{
245 MEMO/SRE/GER-1/No 214/2008 de 17/09/2008. Disponível em: <http://www.cvm.gov.br/export/sites/cvm/noticias/anexos/2008/20081006-1-memo-sre.pdf . Acesso em: 20/04/2016.

${ }^{246}$ Processo Administrativo Sancionador CVM n RJ 2005/1443. Rel. Pedro Oliva Marcilio de Sousa. Disponível em: <http://www.cvm.gov.br/sancionadores/sancionador/2006/20060510_RJ20051443.html>. Acesso em: 20/04/2016.

247 CHEDIAK, Julian Fonseca Peña. O Modelo ANBID: Autorregulação Voluntária em Complemento à Regulação Estatal. Rio de Janeiro, abril de 2009. p. 17.
} 
Atualmente, a autorregularão se dá, basicamente, no âmbito da BM\&FBovespa e da CETIP S.A. - Balcão Organizado de Ativos e Derivativos. $^{248}$

A BM\&FBovespa, em específico, é uma companhia que administra mercados organizados de títulos, valores mobiliários e contratos derivativos, além de prestar serviços de registro, compensação e liquidação, atuando, principalmente, como contraparte central garantidora da liquidação financeira das operações realizadas em seus ambientes. ${ }^{249}$

A bolsa possui a Câmara de Arbitragem do Mercado (CAM), que é considerado o foro mais adequado para resolver disputas societárias e do mercado de capitais. A CAM atua na administração de procedimentos arbitrais originários de conflitos surgidos no âmbito das companhias comprometidas com a adoção de práticas diferenciadas de governança corporativa e transparência, cujas ações são listadas na BM\&FBovespa, e também em outros litígios entre pessoas físicas e jurídicas, desde que sejam referentes a direito empresarial. O ambiente é independente, sigiloso e eficiente para a solução de controvérsias, pautado nas diretrizes da Lei de Arbitragem. ${ }^{250}$

\subsection{1 - Diagnósticos da América S.A. e Cromossomo Participações II S.A. (Caso da Câmara de Arbitragem da BM\&FBovespa)}

No âmbito da aquisição de controle da Dasa pela Cromossomo, o Conselho de Administração da Dasa entendeu que a OPA de aquisição de controle da Cromossomo ensejaria a realização de OPA prevista no art. 45 do estatuto social da Dasa (Brazilian pill). ${ }^{251}$

Tendo em vista a divergência com o Conselho de Administração da Dasa, a Cromossomo recorreu à Câmara de Arbitragem do Mercado da

\footnotetext{
${ }^{248}$ Ibid. p. 17.

$249 \quad$ Disponível em: <http://www.bmfbovespa.com.br/pt-br/intros/intro-sobre-abolsa.aspx?idioma=pt-br $>$.

250 Disponível em: <http://www.bmfbovespa.com.br/pt-br/regulacao/camara-de-arbitragem-domercado/camara-de-arbitragem-do-mercado.aspx?idioma=pt-br $>$.
} 
BM\&FBovespa (“CAM”) para firmar uma decisão de caráter definitivo, encerrando a discussão ${ }^{252}$ e, após adquirir o controle, ${ }^{253}$ ainda, contou com pareceres de juristas que adotavam tese contrária ao do Conselho de Administração da Dasa. ${ }^{254}$

Por fim, a CAM julgou procedente o pedido da Cromossomo para declarar que a mesma não estava obrigada a realizar a oferta pública para aquisição de ações da Dasa (art. 45 do estatuto social da Companhia). ${ }^{255}$

Para o escritório Trindade Sociedade de Advogados (parecer) ${ }^{256}$, a OPA estatutária da Dasa visava proteger a dispersão acionária, lidando com os seguintes riscos da concentração: (i) consolidação de controle majoritário ou minoritário em mãos de um acionista ou grupo de acionistas que possa alterar a condução dos negócios sociais; e (ii) perda de liquidez das ações.

Segundo o parecer, como a ofertante da OPA de aquisição de controle Cromossomo era controlada por dois acionistas da Dasa que detinham maior participação no capital, a oferta, se bem-sucedida, teria o efeito de consolidar o controle na mão desses acionistas.

A questão levantada foi se a OPA Cromossomo por si só já não cumpriria as finalidades da OPA estatutária, dispensando a realização da segunda. Para o escritório, a resposta seria afirmativa, caso a OPA Cromossomo observasse os requisitos objetivos da OPA estatutária.

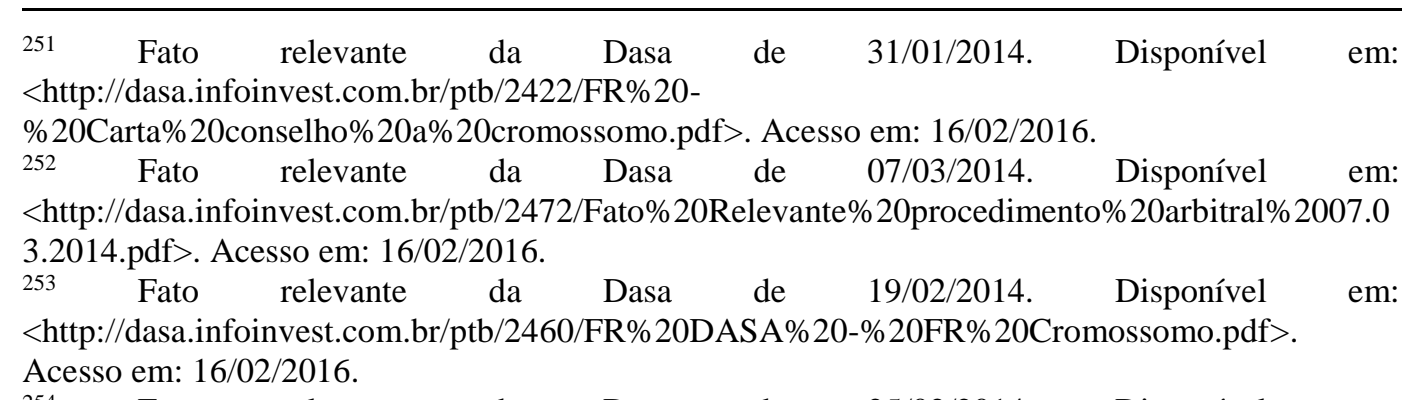

254 Fato relevante da Dasa de 25/02/2014. Disponível em: <http://dasa.infoinvest.com.br/ptb/2468/AnexoI_CompilaodePareceres_FEV2014CormossomoOP AEstatutria.pdf>. Acesso em: 16/02/2016.

255 Fato relevante da Dasa de 01/12/2014. Disponível em: $<$ http://dasa.infoinvest.com.br/ptb/2683/FR\%20DASA\%20-

$\% 20$ Arbitragem\%20DG\%20\%281\%29\%20vf.pdf>. Acesso em: 15/05/2016.

${ }^{256}$ Parecer de Marcelo Trindade. Não Incidência de Cláusula de Proteção à Dispersão Acionária: aquisição por meio de oferta pública voluntária que preenche os requisitos da cláusula de proteção. Disponível 
Isso porque, ao tratar dos riscos já citados, decorrentes da concentração, a solução do estatuto foi exatamente de obrigar a realização de OPA para assegurar liquidez a todos os acionistas, simultaneamente, e nas mesmas condições. E ainda, o estatuto previa a OPA estatuária, pois a concentração acionária em companhias de capital disperso normalmente ocorre por meio de aquisições em bolsa ou privadas, segundo o parecer.

Nesses casos, atingido o limite de aquisição estatutário, haveria o disparo da obrigação de realização da OPA. No entanto, se a OPA de aquisição de controle preenchesse os mesmos requisitos da OPA estatutária, o risco se consumaria ao mesmo tempo em que o remédio de assegurar a liquidez se verificaria.

Assim, entendeu-se no parecer que a OPA Cromossomo preenchia todos os requisitos da OPA estatutária, servindo aos acionistas da Dasa a oportunidade de liquidez que o estatuto quis assegurar-lhes. Entendeu, portanto, que, ainda que as formalidades do estatuto não fossem observadas, substancialmente a obrigação tinha sido cumprida, não podendo ser novamente exigida.

\subsection{2 - Regulamento de Listagem do Novo Mercado}

O Regulamento de Listagem do Novo Mercado estabelece, em seu dispositivo 3.1.2 257 , que as companhias listadas nesse segmento não poderão prever em seus estatutos sociais, exceto nos casos exigidos em lei ou regulamentação aplicável, disposições que: (i) estabeleçam quórum qualificado para a deliberação de matérias que devam ser submetidas à assembleia geral de acionistas; e (ii) impeçam o exercício de voto favorável ou imponham ônus aos acionistas que votarem favoravelmente à supressão de ou alteração de cláusulas estatutárias.

<http://dasa.infoinvest.com.br/ptb/2468/AnexoI_CompilaodePareceres_FEV2014CormossomoOP AEstatutria.pdf>. Acesso em: 16/02/2016.

257 “3.1.2 Disposições do Estatuto Social. Exceto nos casos exigidos em lei ou regulamentação aplicável, as Companhias não poderão prever, em seus estatutos sociais, disposições que: (i) estabeleçam quorum qualificado para a deliberação de matérias que devam ser submetidas à assembleia geral de acionistas; e (ii) impeçam o exercício de voto favorável ou imponham ônus aos acionistas que votarem favoravelmente à supressão ou alteração de cláusulas estatutárias." 
Tal previsão representa um avanço, pois acaba com a suspensão de direitos de acionistas e cláusulas pétreas em companhias listadas no Novo Mercado, ressalvadas as peculiaridades do dispositivo $14.5^{258}$, que trata das companhias que já possuíam valores mobiliários de sua emissão admitidos à negociação no Novo Mercado na data da entrada em vigor da reforma do Regulamento de Listagem, em 10/05/2011.

E, principalmente, conforme o dispositivo $4.8^{259}$, o Regulamento ainda prevê a necessidade de o Conselho de Administração elaborar parecer sobre toda e qualquer oferta pública de aquisição que tenha por objeto as ações de emissão da Companhia listada, em linha com o que ocorre nos Estados Unidos, onde o Conselho de Administração detém ainda mais autonomia para tratar sobre a aceitação ou não de uma oferta. Nos Estados Unidos, os conselheiros simplesmente podem adotar a medida de defesa Just Say No, recusando uma oferta sem qualquer fundamentação, e sem que seja necessária a chancela dos acionistas, enquanto no Brasil, isso não é possível.

Especificamente sobre isso, já dizia PRADO:

\footnotetext{
258 “14.5 Disposições de Transição para as Companhias já Listadas. As Companhias que possuíam valores mobiliários de sua emissão admitidos à negociação no Novo Mercado na data da entrada em vigor da reforma do Regulamento de Listagem, em 10/05/2011: (i) terão o prazo de 3 (três) anos, contados a partir da referida data, para adaptar seus estatutos sociais de modo a cumprir as disposições previstas no item 4.4 deste Regulamento de Listagem; (ii) poderão manter suas disposições estatutárias, em vigor na referida data, que estabeleçam quorum qualificado de deliberação e/ou imponham ônus aos acionistas que votarem favoravelmente à supressão ou alteração de cláusulas estatutárias, que não poderão ser alteradas, salvo quando visarem à exclusão em cumprimento ao disposto no item 3.1.2(i) e/ou (ii) deste Regulamento de Listagem; e (iii) poderão manter suas disposições estatutárias, em vigor na referida data, que limitem o número de votos de acionista ou Grupo de Acionistas em percentuais inferiores a 5\% (cinco por cento) do capital social exclusivamente na hipótese de deliberação de alteração de cláusula estatutária sobre oferta pública de aquisição de ações para o acionista que atingir determinada participação no capital social, sendo que tal limitação de voto somente poderá ser alterada quando visar à sua adaptação em cumprimento ao disposto no item 3.1.1 deste Regulamento de Listagem."

259 "4.8. Manifestação do Conselho de Administração. O Conselho de Administração da Companhia deverá elaborar e tornar público parecer prévio fundamentado sobre toda e qualquer oferta pública de aquisição que tenha por objeto as ações de emissão da Companhia, no qual se manifestará: (i) sobre a conveniência e oportunidade da oferta quanto ao interesse do conjunto dos acionistas e em relação à liquidez dos valores mobiliários de sua titularidade; (ii) sobre as repercussões da oferta sobre os interesses da Companhia; (iii) quanto aos planos estratégicos divulgados pelo ofertante em relação à Companhia; e (iv) outros pontos que considerar pertinentes. No parecer, o Conselho de Administração deverá manifestar opinião fundamentada favorável ou contrária à aceitação da oferta pública de aquisição de ações, alertando que é responsabilidade de cada acionista a decisão final acerca da aceitação, ou não, da referida oferta."
} 
À luz do que ocorre nos Estados Unidos, pode ser interessante adotarmos, no Brasil, semelhante atuação - no mínimo estatutária - do Conselho de Administração nos casos de ofertas públicas de aquisição de ações de companhias que possuam poison pills, devendo o Conselho, no exercício dos seus deveres de lealdade e diligência, conforme os artigos 153 e seguintes da Lei das S/A, encaminhar a discussão sobre a conveniência de sua supressão em assembleia, após criteriosa análise da oferta e sempre zelando pelo interesse de todos os acionistas da companhia. ${ }^{260}$

Ou seja, ainda que o Regulamento, na parte final do dispositivo 4.8, sugira que o Conselho de Administração tem um dever meramente opinativo acerca da aceitação ou não da oferta, sendo responsabilidade de cada acionista sua decisão final, os administradores devem pautar suas ações nos deveres de lealdade, de informação e de diligência a que estão sujeitos. ${ }^{261}$ Além disso, também devem observar esses deveres ao se posicionarem diante de tomadas hostis de controle e mecanismos de proteção.

\footnotetext{
${ }^{260}$ PRADO, Roberta Nioac. Desconcentração do Poder de Controle e Poison Pills: Evolução no Mercado de Capitais Brasileiro. In: CASTRO, Rodrigo R. Monteiro de; MOURA AZEVEDO, Luís André N. de (Coord.). Poder de Controle e Outros Temas de Direito Societário e Mercado de Capitais. São Paulo: Quartier Latin. 2010. p. 408

${ }^{261}$ SHIGUEMATSU, Plínio José Lopes. Mecanismos de proteção e estratégias de defesa em tomadas hostis de controle. In: CASTRO, Rodrigo R. Monteiro de; ARAGÃO, Leandro Santos de (coord.). Direito Societário - Desafios Atuais. São Paulo: Quartier Latin, 2009. p. 438.
} 


\section{CAPÍTULO 6 - OS DEVERES DOS ADMINISTRADORES NA LEI DAS S.A.}

O estudo dos deveres dos administradores consiste em um dos aspectos mais importantes da Lei das S.A. no que se refere ao funcionamento das sociedades por ações, ainda mais em razão do fenômeno representado pela separação entre a propriedade e gestão de companhias constatado por BERLE e MEANS. ${ }^{262}$

Os administradores, sobretudo, aqueles das companhias com capital pulverizado, detêm grande parte do poder empresarial, e muitas vezes o verdadeiro poder, de fato, é exercido na administração da companhia e não na assembleia geral, ainda mais por conta do absenteísmo dos acionistas. ${ }^{263}$

Não obstante a isso, nota NASCIMENTO:

A preocupação do legislador pátrio foi estabelecer padrões de comportamento, a fim de guiar a atuação dos administradores da companhia, tendo este propósito sido refletido na Exposição de Motivos da Lei ${ }^{\circ}$ 6.404/76 ao referir-se à "enumeração minuciosa, e até pedagógica, [d]os deveres e responsabilidades dos administradores". Sendo assim, deve-se examinar de que maneira os padrões de comportamento estabelecidos pelo legislador brasileiro amoldam-se às reflexões sobre tomadas de controle e às defesas adotadas em oposição a estas últimas. ${ }^{264}$

Portanto, o estudo dos deveres dos administradores também é fundamental para fins de análise da atuação dos administradores diante de aquisições hostis de controle e da adoção dos mais diversos mecanismos de proteção.

\section{1 - Dever de diligência}

Primeiramente, a Lei das S.A. determina o dever de diligência em seu artigo $153^{265}$, estabelecendo que o administrador deve empregar, no

\footnotetext{
${ }^{262}$ CAMPOS, Luiz Antonio de Sampaio. Deveres e Responsabilidades. In: LAMY FILHO, Alfredo; BULHÕES PEDREIRA, José Luiz. Direito das Companhias. Volume I. Rio de Janeiro: Forense, 2009. p. 1084.

${ }^{263}$ Ibid. p. 1085.

${ }^{264}$ NASCIMENTO, João Pedro Barroso do. Medidas Defensivas à Tomada de Controle de Companhias. São Paulo: Quartier Latin, 2011. p. 228.

${ }^{265}$ Art. 153. O administrador da companhia deve empregar, no exercício de suas funções, o cuidado e diligência que todo homem ativo e probo costuma empregar na administração dos seus próprios negócios.
} 
exercício de suas funções, o cuidado e a diligência que todo homem ativo e probo costuma empregar na administração de seus próprios negócios.

Aqui está, conforme CAMPOS ${ }^{266}$, a "chave" da responsabilização dos administradores, pois esse é o padrão de comportamento ao qual se refere a exposição de motivos da Lei das S.A. ${ }^{267}$ e do qual se desdobram os demais deveres.

$\mathrm{O}$ autor afirma ainda que embora seja genérico, esse padrão tem conteúdo específico, equivocando-se aqueles que o assimilam ao comportamento do pater familiae. Na verdade, o critério da Lei está inerentemente ligado ao do homem de negócios, o businessman do direito anglo-saxão.

Essa distinção é importante, pois o comportamento do bom pai de família não se ajusta ao do administrador. O modelo do pai de família, proveniente do direito romano, diz respeito a uma pessoa conservadora e avessa a riscos, preocupada mais em preservar o patrimônio do que aumenta-lo. A estrutura da companhia pressupõe a propensão ao risco empresarial. ${ }^{268}$

\subsection{1 - Dever de se informar}

266 CAMPOS, Luiz Antonio de Sampaio. Deveres e Responsabilidades. In: LAMY FILHO, Alfredo; BULHÕES PEDREIRA, José Luiz. Direito das Companhias. Volume I. Rio de Janeiro: Forense, 2009. p. 1097.

267 "Os artigos 154 a 161 definem, em enumeração minuciosa, e até pedagógica, os deveres e responsabilidades dos administradores. É Seção da maior importância no Projeto porque procura fixar os padrões de comportamento dos administradores, cuja observância constitui a verdadeira defesa da minoria e torna efetiva a imprescindível responsabilidade social do empresário. Não é mais possível que a parcela de poder, em alguns casos gigantesca, de que fruem as empresas - e, através delas, seus controladores e administradores - seja exercido em proveito apenas de sócios majoritários ou dirigentes, e não da companhia, que tem outros sócios, e em detrimento, ou sem levar em consideração, os interesses da comunidade. As normas desses artigos são, em sua maior parte, meros desdobramentos e exemplificações do padrão de comportamento dos administradores definido pela lei em vigor - o do "homem ativo e probo na administração dos seus próprios negócios" ( $\$ 7^{\circ}$ do art. 116 do Decreto-lei $\left.n^{\circ} 2.627\right)$ e, em substância, são as que vigoram, há muito tempo, nas legislações de outros povos; formuladas, como se encontram, tendo presente a realidade nacional, deverão orientar os administradores honestos, sem entorpecê-los na ação, com excessos utópicos. Servirão, ainda, para caracterizar e coibir abusos."

268 CAMPOS, Luiz Antonio de Sampaio. Deveres e Responsabilidades. In: LAMY FILHO, Alfredo; BULHÕES PEDREIRA, José Luiz. Direito das Companhias. Volume I. Rio de Janeiro: Forense, 2009. p. 1100-1101. 
O dever de se informar diz respeito ao procedimento de um administrador diligente tomar decisões de maneira informada. Em outras palavras, significa que o administrador deve procurar se informar sobre os negócios da companhia em geral e buscar obter os dados necessários para uma diligente tomada de decisão. ${ }^{269}$

\subsection{2 - Dever de vigilância}

O dever de vigilância diz respeito não a atos específicos, mas sim a uma vigilância geral. Isso quer dizer que o administrador deve monitorar o andamento dos negócios, a execução das deliberações e decisões tomadas. $^{270}$

\subsection{3 - Dever de investigar}

O dever de investigar dos administradores diz respeito a fatos que tomem conhecimento ou que despertem algum interesse em particular. No caso, os administradores devem examinar criticamente as informações que recebem sem que isso lhes retire o direito de confiar nas informações recebidas por outros administradores ou empregados da companhia. Esse princípio decorre do dever de se informar. ${ }^{271}$

\subsection{4 - Dever de intervir}

Quando o administrador constatar algum indício de irregularidade, há o dever de agir ou intervir. Esse dever integra o dever de investigar. ${ }^{272}$

\subsection{5 - Dever de assiduidade}

O dever de assiduidade diz respeito à obrigação de comparecer às reuniões de conselho de administração e diretoria, conforme o caso. Esse dever integra o dever de diligência. ${ }^{273}$

\section{2 - Dever de lealdade}

O artigo $155^{274}$ da Lei da S.A. prevê que os administradores devem servir com lealdade à companhia, bem como guardar reserva a respeito de

\footnotetext{
269 Ibid. p. 1106.

270 Ibid. p. 1107.

271 Ibid. p. 1108

272 Ibid. p. 1110

273 Ibid. p. 1110.
} 
seus negócios. ${ }^{275}$ Também ganhou projeção no cenário norte-americano o conceito do standard of loyalty, que constitui boa fonte de comparação jurídica para o aplicador do direito, mas que deve ser estudado com devida atenção à diferença dos sistemas.

Em observância a esse princípio, o administrador não só não deve obter benefícios às custas da sociedade, como também deve evitar que a companhia, por ato ou omissão sua, sofra prejuízo ou deixe de auferir benefício. ${ }^{276}$

\section{Como afirma MÜSSNICH:}

O dever de lealdade impede que os administradores usem em benefício próprio ou de outrem, as oportunidades comerciais que lhes são proporcionadas em decorrência do cargo que ocupam. O fundamento legal desta obrigação é que os administradores devem exercer as suas funções no interesse da empresa, tendo em vista a sua função social. ${ }^{277}$

\section{3 - Dever de sigilo}

\section{Como informa REQUIÃO:}

Quando o Presidente Franklin Delano Roosevelt, no início da década de 1930, enfrentou a depressão econômica causada pela crise bolsista de 1929, e instituiu a política do New Deal, preocupou-se em sanear e moralizar o mercado financeiro e acionário dos Estados Unidos, sujeitando as corporations a severa fiscalização,

\footnotetext{
${ }^{274}$ Art. 155. O administrador deve servir com lealdade à companhia e manter reserva sobre os seus negócios, sendo-lhe vedado: I - usar, em benefício próprio ou de outrem, com ou sem prejuízo para a companhia, as oportunidades comerciais de que tenha conhecimento em razão do exercício de seu cargo; II - omitir-se no exercício ou proteção de direitos da companhia ou, visando à obtenção de vantagens, para si ou para outrem, deixar de aproveitar oportunidades de negócio de interesse da companhia; III - adquirir, para revender com lucro, bem ou direito que sabe necessário à companhia, ou que esta tencione adquirir. $\S 1^{\circ}$ Cumpre, ademais, ao administrador de companhia aberta, guardar sigilo sobre qualquer informação que ainda não tenha sido divulgada para conhecimento do mercado, obtida em razão do cargo e capaz de influir de modo ponderável na cotação de valores mobiliários, sendo-lhe vedado valer-se da informação para obter, para si ou para outrem, vantagem mediante compra ou venda de valores mobiliários. $\S 2^{\circ} \mathrm{O}$ administrador deve zelar para que a violação do disposto no $\S 1^{\circ}$ não possa ocorrer através de subordinados ou terceiros de sua confiança. $\S 3^{\circ}$ A pessoa prejudicada em compra e venda de valores mobiliários, contratada com infração do disposto nos $\S \S 1^{\circ}$ e $2^{\circ}$, tem direito de haver do infrator indenização por perdas e danos, a menos que ao contratar já conhecesse a informação. § 4o É vedada a utilização de informação relevante ainda não divulgada, por qualquer pessoa que a ela tenha tido acesso, com a finalidade de auferir vantagem, para si ou para outrem, no mercado de valores mobiliários. (Incluído pela Lei no 10.303 , de 2001)

275 CAMPOS, Luiz Antonio de Sampaio. Deveres e Responsabilidades. In: LAMY FILHO, Alfredo; BULHÕES PEDREIRA, José Luiz. Direito das Companhias. Volume I. Rio de Janeiro: Forense, 2009. p. 1128.

276 Ibid. p. 1129.

277 MÜSSNICH, Francisco Antunes Maciel. A utilização desleal de informações privilegiadas "Insider Trading" - no Brasil e nos Estados Unidos. Revista de direito mercantil, industrial, econômico e financeiro $\mathrm{n}^{\circ}$ 34, Abril/Junho de 1979, Ano XVIII. p. 33.
} 
ao mesmo tempo que instituía a Securities and Exchange Commission, como agência do governo para policiar o mercado de capitais. Surgiu uma legislação repressora da prática das transações feitas dentro da sociedade, por diretores bem informados sobre os negócios sociais. A esses atos de deslealdade deu-os a doutrina norte-americana a conhecer sob a designação de insider trading. Os objetivos do direito norte-americano são precisamente "pôr os proprietários de títulos em posição de igualdade, tanto quanto possível, com os dirigentes das sociedades emissoras e, no que diz respeito à informação disponível, colocar o comprador em pé de igualdade com o vendedor'. A intenção final desse sistema, como disse uma decisão judicial, é 'proteger os que ignoram as condições do mercado contra os abusos do que as conhecem' ${ }^{278}$

Cumpre destacar que o direito norte-americano inspirou a regra do artigo 3º, X, da Lei n 4.728, de 1965 ("Lei de Mercado de Capitais") 279 que conferiu a atribuição ao Banco Central do Brasil ("BACEN") de fiscalizar a utilização de informações não divulgadas ao público em benefício próprio ou de terceiros, por acionistas ou pessoas que, por força de cargos que exerçam, a elas tenham acesso.

Além disso, o artigo $155, \S 1^{\circ}$ da Lei das S.A. ${ }^{280}$, bem como o artigo $8^{\circ}$ da ICVM $358^{281}$, estabelece que cumpre ao administrador guardar sigilo sobre qualquer informação que ainda não tenha sido divulgada ao do mercado.

\section{Em razão disso, afirma REQUIÃO:}

Deve o administrador zelar, diz a lei, como se viu, para que a violação do segredo da sociedade não possa ocorrer através de subordinados ou terceiros de sua

\footnotetext{
${ }^{278}$ REQUIÃO, Rubens. Curso de direito comercial. $2^{\circ}$ volume. 31. ed. São Paulo: Saraiva, 2014. p. 270.

279 Art. $3^{\circ}$ Compete ao Banco Central: [...] X - fiscalizar a utilização de informações não divulgadas ao público em benefício próprio ou de terceiros, por acionistas ou pessoas que, por força de cargos que exerçam, a elas tenham acesso.

280 Art. 155. O administrador deve servir com lealdade à companhia e manter reserva sobre os seus negócios, sendo-lhe vedado: [...] $] 1^{\circ}$ Cumpre, ademais, ao administrador de companhia aberta, guardar sigilo sobre qualquer informação que ainda não tenha sido divulgada para conhecimento do mercado, obtida em razão do cargo e capaz de influir de modo ponderável na cotação de valores mobiliários, sendo-lhe vedado valer-se da informação para obter, para si ou para outrem, vantagem mediante compra ou venda de valores mobiliários.

${ }^{281}$ Art. $8^{\circ}$ Cumpre aos acionistas controladores, diretores, membros do conselho de administração, do conselho fiscal e de quaisquer órgãos com funções técnicas ou consultivas, criados por disposição estatutária, e empregados da companhia, guardar sigilo das informações relativas a ato ou fato relevante às quais tenham acesso privilegiado em razão do cargo ou posição que ocupam, até sua divulgação ao mercado, bem como zelar para que subordinados e terceiros de sua confiança também o façam, respondendo solidariamente com estes na hipótese de descumprimento.
} 
confiança. Entre 'terceiros de sua confiança' se incluem, naturalmente, além dos amigos íntimos e sócios em outros negócios extrassociais, os seus familiares. ${ }^{282}$

Sendo assim, por força do dever de sigilo, os administradores, em razão da posição em que ocupam dentro da companhia, devem guardar reserva de toda e qualquer informação não pública que tenham tido conhecimento na época em que estavam exercendo a função de administradores, até mesmo para evitar que haja o uso indevido de informação privilegiada por terceiros. ${ }^{283}$

\section{4 - Dever de informar}

\section{Conforme REQUIÃO:}

Outro instituto de relevância, transplantado do direito norte-americano pela atual lei, é a disclosure. Trata-se do dever de revelar certas situações e negócios em que a companhia e os administradores estão empenhados, e que podem influir no mercado, no que se refere aos valores mobiliários por ela emitidos. A disclosure constitui, pois, um conjunto de regras que visam a proteger a lisura e a respeitabilidade do mercado de capitais. Não se refere propriamente à informação sobre os negócios inerentes à realização do objeto social da companhia, pois esses integram e são protegidos pelos princípios do sigilo profissional da empresa, mas diz respeito a tudo aquilo que possa influir na cotação dos valores mobiliários (ações, debêntures etc.) emitidos pela companhia, e que são objeto de operações do mercado. ${ }^{284}$

O dever de informar está previsto no artigo $157^{285}$ da Lei das S.A., que enuncia as regras que a companhia deve seguir para manter o mercado

${ }^{282}$ REQUIÃO, Rubens. Curso de direito comercial. $2^{\circ}$ volume. 31. ed. São Paulo: Saraiva, 2014. p. 271.

${ }^{283}$ CAMPOS, Luiz Antonio de Sampaio. Deveres e Responsabilidades. In: LAMY FILHO, Alfredo; BULHÕES PEDREIRA, José Luiz. Direito das Companhias. Volume I. Rio de Janeiro: Forense, 2009. p. 1143-1144.

${ }^{284}$ REQUIÃO, Rubens. Curso de direito comercial. $2^{\circ}$ volume. 31. ed. São Paulo: Saraiva, 2014. 277.

285 Art. 157. O administrador de companhia aberta deve declarar, ao firmar o termo de posse, o número de ações, bônus de subscrição, opções de compra de ações e debêntures conversíveis em ações, de emissão da companhia e de sociedades controladas ou do mesmo grupo, de que seja titular. (Vide Lei $\mathrm{n}^{\mathrm{o}} 12.838$, de 2013) $\S 1^{\circ} \mathrm{O}$ administrador de companhia aberta é obrigado a revelar à assembléia-geral ordinária, a pedido de acionistas que representem $5 \%$ (cinco por cento) ou mais do capital social: a) o número dos valores mobiliários de emissão da companhia ou de sociedades controladas, ou do mesmo grupo, que tiver adquirido ou alienado, diretamente ou através de outras pessoas, no exercício anterior; b) as opções de compra de ações que tiver contratado ou exercido no exercício anterior; c) os benefícios ou vantagens, indiretas ou complementares, que tenha recebido ou esteja recebendo da companhia e de sociedades coligadas, controladas ou do mesmo grupo; d) as condições dos contratos de trabalho que tenham sido firmados pela companhia com os diretores e empregados de alto nível; e) quaisquer atos ou fatos relevantes nas atividades da companhia. $\S 2^{\circ}$ Os esclarecimentos prestados pelo administrador poderão, a pedido de qualquer acionista, ser reduzidos a escrito, autenticados pela mesa da 
plenamente informado, a respeito de sua política e seus negócios, que nele

podem influir. ${ }^{286}$ Esse dever, portanto, desdobra-se na obrigação de informação aos acionistas e ao mercado. ${ }^{287}$

Cabe ressaltar que a CVM atua, decisivamente, na fiscalização da prestação dessas informações. ${ }^{288}$

assembléia, e fornecidos por cópia aos solicitantes. $\S 3^{\circ} \mathrm{A}$ revelação dos atos ou fatos de que trata este artigo só poderá ser utilizada no legítimo interesse da companhia ou do acionista, respondendo os solicitantes pelos abusos que praticarem. $\S 4^{\circ}$ Os administradores da companhia aberta são obrigados a comunicar imediatamente à bolsa de valores e a divulgar pela imprensa qualquer deliberação da assembléia-geral ou dos órgãos de administração da companhia, ou fato relevante ocorrido nos seus negócios, que possa influir, de modo ponderável, na decisão dos investidores do mercado de vender ou comprar valores mobiliários emitidos pela companhia. $\S 5^{\circ}$ Os administradores poderão recusar-se a prestar a informação $\left(\S 1^{\circ}\right.$, alínea e), ou deixar de divulgá-la $\left(\S 4^{\circ}\right)$, se entenderem que sua revelação porá em risco interesse legítimo da companhia, cabendo à Comissão de Valores Mobiliários, a pedido dos administradores, de qualquer acionista, ou por iniciativa própria, decidir sobre a prestação de informação e responsabilizar os administradores, se for o caso. § 6o Os administradores da companhia aberta deverão informar imediatamente, nos termos e na forma determinados pela Comissão de Valores Mobiliários, a esta e às bolsas de valores ou entidades do mercado de balcão organizado nas quais os valores mobiliários de emissão da companhia estejam admitidos à negociação, as modificações em suas posições acionárias na companhia. (Incluído pela Lei n ${ }^{\circ} 10.303$, de 2001)

${ }^{286}$ REQUIÃO, Rubens. Curso de direito comercial. $2^{\circ}$ volume. 31. ed. São Paulo: Saraiva, 2014. P 278.

287 CAMPOS, Luiz Antonio de Sampaio. Deveres e Responsabilidades. In: LAMY FILHO, Alfredo; BULHÕES PEDREIRA, José Luiz. Direito das Companhias. Volume I. Rio de Janeiro: Forense, 2009. p. 1171.

${ }^{288}$ REQUIÃO, Rubens. Curso de direito comercial. $2^{\circ}$ volume. 31. ed. São Paulo: Saraiva, 2014. p. 279. 


\section{CAPÍTULO 7 - EXAME DA APLICAÇÃO E PERTINÊNCIA DOS MECANISMOS DE PROTEÇÃO NO BRASIL}

Após o fornecimento de parâmetros necessários à análise da pesquisa empírica realizada por este trabalho. Finalmente, faz-se a análise prática dos mecanismos de proteção aplicados no Brasil.

Primeiramente, conforme NASCIMENTO, os efeitos das medidas são os seguintes: (i) estabilização da dispersão acionária; (ii) efeito no preço de compra; (iii) efeito disciplinar em relação à administração; (iv) desestímulo ao investimento; e (v) envolvimento da administração na negociação ${ }^{289}$.

As companhias dotadas de dispersão acionária ficam mais protegidas contra eventuais tomadas hostis de controle com as medidas de proteção. Além disso, as medidas de proteção tendem a elevar o preço de compra das ações, inclusive, para desestimular eventual ofertante hostil de adquirir o controle da companhia. No entanto, alguns defendem, por outro lado, que as medidas defensivas causam a redução do valor das ações, e diminuem a ocorrência de ofertas públicas.

Em companhias com ações dispersas no mercado, a possibilidade de tomada de controle, aliada à inexistência de proteções, faz com que os administradores atuem de forma eficiente na gestão das companhias. Entretanto, a adoção de medidas de defesa pode acabar protegendo a manutenção de uma administração ineficiente, que corre o risco de ser substituída após a tomada de controle.

Alguns acreditam que as medidas de proteção desestimulam investimentos estratégicos, já que investidores de mercado costumam evitar aplicar recursos em companhias que podem restringir a circulação de suas ações.

\footnotetext{
289 NASCIMENTO, João Pedro Barroso do. Medidas Defensivas à Tomada de Controle de Companhias. São Paulo: Quartier Latin, 2011. p. 191-198.
} 
E ainda, por outro lado, as medidas de defesa funcionam como instrumentos de envolvimento da administração da companhia na negociação da oferta, pois levam os potenciais adquirentes a procurar a administração para discutir o preço.

Dentre os inúmeros argumentos que podem ser utilizados contra e a favor da adoção de mecanismos de proteção contra a tomada hostil de controle, talvez o mais importante e de especial interesse deste trabalho seja em relação à questão do eventual entrincheiramento (entrenchment) da administração (no caso de um controle gerencial) e/ou dos acionistas controladores (no caso de um controle difuso, minoritário ou compartilhado).

Afinal, os mecanismos no Brasil atendem à finalidade de proteção dos acionistas ou são mais utilizados como instrumentos de entrincheiramento?

Qualquer que seja a resposta a essa indagação, nenhuma delas é absoluta. No entanto, faz-se necessário a reflexão crítica sobre a aplicação dos mecanismos no cenário em que vêm sendo aplicados e da forma como vêm sendo aplicados.

Conforme CARVALHOSA, a licitude e legitimidade dessas iniciativas ou medidas devem ser analisadas sob a perspectiva da estrutura de capital acionário da companhia. ${ }^{290}$

Como bem visto anteriormente, no Brasil, predomina o fenômeno da concentração acionária. Conforme dados extraídos da análise feita pela Revista Capital Aberto em 2015, das 100 companhias com as ações mais líquidas da bolsa, 47\% possuíam controle majoritário, 49\% possuíam controle minoritário ou compartilhado, e apenas $4 \%$ possuíam capital pulverizado. ${ }^{291}{ }^{292}$

\footnotetext{
290 CARVAlHOSA, Modesto. As Poison Pills Estatutárias na Prática Brasileira - Alguns Aspectos de sua Legalidade. In: CASTRO, Rodrigo R. Monteiro de; ARAGÃO, Leandro Santos de (Coord.). Direito Societário - Desafios Atuais. São Paulo: Quartier Latin, 2009. p. 20.

${ }^{291}$ De acordo com o levantamento da Revista Capital Aberto, em 2015, 47\% das companhias analisadas possuíam controle majoritário, $49 \%$ possuíam controle minoritário ou compartilhado, e
} 
Ainda, segundo a Revista Capital Aberto, em 2015, 29\% das companhias analisadas apresentavam "poison pill" no estatuto e, dentre essas companhias com “poison pill”, 21\% apresentavam cláusula pétrea. ${ }^{293}$ 294 Ou seja, verifica-se a quantidade substancial de companhias que possuem mecanismos de proteção em um ambiente de mercado marcado pela concentração acionária.

Em análise específica, realizada por este trabalho (Anexo I), de todas as companhias do Novo Mercado em 2016, verificou-se que dentre 130 companhias do Novo Mercado (i) 70,7\% das companhias apresentavam controle definido; (ii) dentre essas companhias de controle definido, 52,1\% apresentavam Brazilian pill; e (iii) dentre essas companhias de controle definido e com Brazilian pill, 22,9\% apresentavam cláusulas pétreas. ${ }^{295}$

Percebe-se, portanto, pela configuração do mercado brasileiro, que em alguns casos, a inserção de shark repellents sob a forma das Brazilian pills em companhias com controle definido pode acabar gerando o reforço e

4\% possuíam capital pulverizado. Segundo a matéria, "Na edição passada deste anuário, os dados indicavam uma tendência de expansão do controle minoritário ou compartilhado (em que o maior acionista não tem mais de $50 \%$ das ações ordinárias). Na publicação deste ano, esse movimento foi revertido e deu lugar ao avanço do controle majoritário. As estatísticas revelam que o número de empresas em que o maior acionista possui mais de $50 \%$ das ações ON subiu de $41 \%$ para $47 \%$. Já o percentual de companhias com controle minoritário ou compartilhado caiu de $54 \%$ para $49 \%$." (Concentração de poder. Aumenta percentual de companhias com sócio majoritário. Anuário de Governança Corporativa das Companhias Abertas 2015-2016. Revista Capital Aberto. N 43. p. 07).

292 Segundo o anuário da Revista Capital Aberto, em 2015, apenas quatro companhias se encaixavam no grupo de companhias com capital pulverizado (em que o maior acionista detém menos de $10 \%$ do capital votante): Kroton, Valid, Cyrela e Even. Companhias como Hering e Gafisa, antes pulverizadas, passaram à categoria de controle minoritário ou compartilhado. (Anuário de Governança Corporativa das Companhias Abertas 2015-2016. Revista Capital Aberto. $\mathrm{N}^{\circ}$ 43. p. 07).

293 De acordo com os dados coletados pela Revista Capital Aberto no anuário de 2015-2016, as companhias que apresentam "poison pill" são as seguintes: Aliansce; Anima; Arteris; B2W Digital; BM\&FBovespa; BR Malls; BR Properties; BRF; Cetip; Direcional Engenharia; Embraer; Estácio; Even; Eztec; Fibria; Gafisa; Gol; Iochpe-Maxion; JBS; Lojas Renner; Magazine Luiza; Minerva; Multiplan; Natura; Odontoprev; São Martinho; Sulamérica; Totvs; Valid. Anuário de Governança Corporativa das Companhias Abertas 2015-2016. Revista Capital Aberto. № 43.

${ }^{294}$ De acordo com os dados coletados pela Revista Capital Aberto no anuário de 2015-2016, as companhias que apresentam "cláusula pétrea" acompanhando a "poison pill" são as seguintes: Iochpe-Maxion; Lojas Renner; Multiplan; Odontoprev; Totvs; Valid. (Anuário de Governança Corporativa das Companhias Abertas 2015-2016. Revista Capital Aberto. Ano 6. № 43).

${ }^{295}$ Verificou-se a partir da pesquisa empírica realizada no âmbito deste trabalho que, dentre as 130 companhias do Novo Mercado, (i) 92 companhias apresentavam controle definido; (ii) dentre essas companhias com controle definido, 48 apresentavam Brazilian pill; e (iii) dentre essas companhias de controle definido e com Brazilian pill, 11 apresentavam cláusula pétrea. 
a defesa de um controle já instituído, atendendo a uma finalidade contrária àquela originalmente proposta pelas medidas. E isso se torna ainda mais flagrante quando há a inserção adicional de cláusulas pétreas, com a clara intenção de tornar essas medidas imutáveis. A doutrina é vasta nesse sentido.

\section{TOLEDO argumenta nesse mesmo sentido:}

Note-se, a propósito, que as sociedades anônimas brasileiras com capital pulverizado ainda são uma raridade. Assim, os beneficiários das medidas são, na realidade, não os acionistas - como, idealmente, deveria ser - nem os administradores das companhias (ante a inocorrência da dispersão de propriedade das ações), mas sim os próprios controladores, quer se trate de controle difuso, compartilhado ou minoritário. ${ }^{296}$

CARVALHOSA também chega a defender esse ponto em seu trabalho sobre a legalidade das Brazilian pills:

[...] se é do interesse da companhia unir-se a outra ou ser adquirida, a cláusula de poison pill não pode ser utilizada como pretexto para a manutenção de uma administração ineficiente, a qual corre o risco de ser substituída caso haja essa consolidação que atenderia melhor ao interesse social existente. $\mathrm{O}$ que tem ocorrido atualmente no mercado brasileiro é um desvirtuamento da proposta da poison pill: ao invés de oferecerem a proteção contra ofertas inesperadas de tomada de controle, acabam sendo utilizadas como forma de manutenção do atual controle na companhia, sem levar em consideração a pulverização de parte de seu capital, bem como a possibilidade de maximização do valor da sociedade através da viabilização de propostas de fusão e de aquisição feitas por terceiros, via uma oferta hostil. ${ }^{297}[\ldots]$ a poison pill pode ser definida como um mecanismo jurídico utilizado com o intuito de entrincheirar o grupo controlador e os administradores por ele indicados na companhia. ${ }^{298}$ [...] De uma maneira geral, as vantagens e as desvantagens das poison pills podem assegurar a manutenção do capital pulverizado e a continuidade/estabilidade do grupo controlador minoritário e da sua administração. Porém aumentam a dificuldade de alteração do titular do poder de controle, além de gerarem o desestímulo ao surgimento de um "mercado secundário do poder de controle", benéfico para o mercado como um todo. ${ }^{299}$

Adicionalmente, isso se reitera com o fato de que as medidas de defesa da forma como vêm sendo inseridas nos estatutos sociais de companhias, prevendo preços absurdos e irreais de OPA, reforçam ainda

\footnotetext{
${ }^{296}$ TOLEDO, Paulo Fernando Campos Salles de. Poison pill: Modismo ou Solução? In: CASTRO, Rodrigo R. Monteiro de; ARAGÃO, Leandro Santos de (Coord.). Direito Societário - Desafios Atuais. São Paulo: Quartier Latin, 2009. p. 176.

297 CARVAlHOSA, Modesto. As Poison Pills Estatutárias na Prática Brasileira - Alguns Aspectos de sua Legalidade. In: CASTRO, Rodrigo R. Monteiro de; ARAGÃO, Leandro Santos de (Coord.). Direito Societário - Desafios Atuais. São Paulo: Quartier Latin, 2009. p. 21.

${ }^{298}$ Ibid. p. 22.
} 
mais a tese de que na verdade, muitas vezes, o que se pretende de fato com sua adoção é impossibilitar qualquer tomada de controle, ao invés de atingir as principais finalidades para as quais tais medidas foram propostas, como alcançar melhores condições de oferta e/ou deter/impedir ofertas que sejam coercitivas.

\begin{abstract}
Nesse sentido, afirma EIZIRIK:
Em primeiro lugar, os critérios estatutariamente estabelecidos para a definição do preço a ser adotado na OPA por atingimento de participação relevante tinham por objetivo, em diversas situações, inviabilizar, na prática, qualquer possibilidade de um novo investidor adquirir o controle ou uma participação relevante da companhia. [...] A redação dos dispositivos estatutários [que tratam sobre os preços da OPA] acima mencionados deixa claro que, em tais casos, o objetivo da regra não é proteger os acionistas da companhia com capital pulverizado contra uma tomada de controle ou uma aquisição de participação relevante promovida de forma não equitativa, mas, ao contrário, perpetuar no poder os administradores ou principais acionistas da companhia, impedindo que qualquer outro investidor adquira uma participação acionária relevante. [...] Diante disso, não há dúvida de que as cláusulas estatutárias que estabelecem critérios absurdos e irreais para o cálculo do preço da OPA por atingimento de participação são absolutamente inválidas, na medida em que visam proteger os interesses particulares dos administradores ou de determinados acionistas, prejudicando a própria companhia e os demais acionistas, que ficam impossibilitados de vender suas ações em uma eventual oferta de compra formulada por um terceiro investidor. Com efeito, a ilegalidade de tal cláusula de poison pill decorre do fato de ela inviabilizar operações que potencialmente atenderiam ao interesse da companhia, como, por exemplo, a aquisição de seu controle ou de uma participação relevante por um novo investidor, tendo como único efeito perpetuar no poder os administradores ou principais acionistas da companhia. ${ }^{300}$
\end{abstract}

\title{
Em relação a isso, faz-se necessário considerar as seguintes
}

\section{ponderações de MÜSSNICH e LOBÃO MELO:}

[...] as Brazilian pills, da forma que são previstas hoje nos estatutos sociais das companhias abertas nacionais, são prejudiciais ao mercado em geral e, em muitos casos, à própria companhia em que elas se inserem.

No entanto, as medidas defensivas à aquisição hostil de controle podem em alguns casos ter utilidade, como pílula que são, mas devem ser ministradas parcimoniosamente a quem delas precise e cujo uso é indicado.

Tais medidas, por exemplo podem cumprir seu papel na manutenção da dispersão acionária de uma determinada companhia, porém, não na forma como são elaboradas hoje em dia, com cláusulas pétreas e afins, e sim adaptada à realidade de cada companhia, de cada mercado, de cada universo de acionistas. ${ }^{301}$

\footnotetext{
${ }^{299}$ Ibid. p. 29.

${ }^{300}$ EIZIRIK, Nelson. A legalidade das poison pills adotadas pelas companhias brasileiras. In: Direito societário - estudos e pareceres. São Paulo: Quartier Latin, 2015. p. 600-602.

${ }^{301}$ MÜSSNICH, Francisco Antunes Maciel; LOBÃO MELO, Vitor de Britto. Análise Prática e Considerações sobre a realidade e a aplicação das medidas de proteção à tomada de controle nos
} 
Quanto à inserção das chamadas cláusulas pétreas nos estatutos, a doutrina é praticamente unânime quanto à sua ilegalidade. Sendo o entendimento, praticamente, pacífico de que tais cláusulas são contrárias à Lei. Essas cláusulas evidenciam ainda mais a intenção de perpetuar o controle já instituído ou a administração da companhia, já que preveem sanções desproporcionais a qualquer acionista que vote pela exclusão ou alteração da Brazilian pill.

CARVALHOSA discorre sobre a ilegalidade das referidas cláusulas:

O que se tem observado, contudo, é que a poison pill pretende adquirir em muitos casos, feições de imutabilidade, de verdadeira cláusula "pétrea", evidenciando aquela primeira questão de utilizá-las como mecanismo jurídico de perpetuação de um determinado grupo no controle da companhia. São exemplos deste tipo aberrante as cláusulas estatutárias que punem aqueles acionistas que votarem em assembléia geral pela alteração ou exclusão, obrigando-os a realizar a OPA referente a todas as ações de emissão da companhia, sendo esta a própria oferta prevista na cláusula da poison pill. Percebe-se, neste caso, a extrema ilegalidade e imoralidade deste tipo de cláusula de poison pill, pois constrange o exercício do direito de voto do acionista, o qual deverá ser manifestado, sempre, de forma livre e em consonância com o interesse social.

Esse tipo de punição ao acionista que votar pela alteração ou exclusão da poison pill do estatuto evidencia o ilegítimo intuito de manutenção de administração ineficiente na companhia, frente à possibilidade de sua alteração através de uma possível oferta hostil.

[...] Portanto fica expressa a falta de consonância com o interesse social, mediante a tentativa de sobreposição dos interesses de um pequeno grupo em detrimento dos demais e da própria sociedade. Essa cláusula, absolutamente contrária à lei societária e ao próprio sistema jurídico, destrói a validade, a licitude e a legitimidade das poison pills com tais características de absoluta iniqüidade. ${ }^{302}$

\section{Sobre tais cláusulas, MÜSSNICH e LOBÃO MELO resumem o} seguinte:

Esta limitação do seu direito de voto acaba por desencadear diversas ofensas frontais a princípios basilares do direito societário e normas legais de ordem pública, evidenciando as cláusulas pétreas como dispositivos flagrantemente ilegítimos e ilegais.

estatutos sociais das companhias abertas brasileiras (Brazilian Pills). In: SILVA, Alexandre Couto (Coord.). Direito Societário - Estudos sobre a lei de sociedades por ações. 2013. Editora Saraiva. Disponível em: <http://www.bmalaw.com.br/arquivos/Artigos/DIREITO\%20SOCIET\%C3\%81RIO\%20\%20ESTUDOS\%20SOBRE\%20A\%20LEI\%20DE\%20SOCIEDADES\%20POR\%20A\%C3\%87\% C3\%95ES.PDF>. Acesso em: 13/05/2016. p. 275-276.

302 CARVAlHOSA, Modesto. As Poison Pills Estatutárias na Prática Brasileira - Alguns Aspectos de sua Legalidade. In: CASTRO, Rodrigo R. Monteiro de; ARAGÃO, Leandro Santos de (coord.). Direito Societário - Desafios Atuais. São Paulo: Quartier Latin, 2009. p. 26-27. 
Dentre esses princípios, podemos citar (i) o princípio da soberania da assembleia geral, positivado na Lei das S.A., principalmente na norma constante em seus arts. 121 e 122, que define a assembleia geral como órgão máximo e soberano das companhias brasileiras (inclusive para aprovar a reforma do seu estatuto social art. 122, I); (ii) o princípio majoritário, pelo qual se confere à maioria do capital votante o poder de prevalecer, ressalvadas poucas exceções da lei, nas referidas assembleias (art. 129 da Lei das S.A.); (iii) o próprio direito de voto, pelo qual o acionista, caso o exerça no interesse social, tem total liberdade para escolher como votar (art. 155); e (iv) os princípios da autonomia privada e da liberdade de contratar, pelos quais os indivíduos possuem a liberdade e a autonomia para criar e alterar normas entre si (art. 421 do Código Civil Brasileiro). ${ }^{303}$

Sendo assim, entende-se que os mecanismos de defesa, conforme foram pensados nos Estados Unidos, deveriam atender à finalidade de proteger, de fato, a companhia contra ofertas coercitivas e ofertas que representem uma verdadeira ameaça aos seus negócios ${ }^{304}$. Assim como poderiam também ser utilizados como instrumento para negociação de melhores preços de oferta, dentre outras finalidades que visem defender o melhor interesse da companhia e de seus acionistas.

Para isso, tais medidas não poderiam ser aplicadas e arquitetadas com a finalidade única de impossibilitar uma eventual oferta hostil, como ocorre no caso de muitas Brazilian pills. Essas medidas deveriam ser aplicadas de modo proporcional contra reais ameaças à companhia.

Além disso, as ofertas públicas para a aquisição de controle, muitas vezes, são importantes para o desenvolvimento do mercado de capitais, já

\footnotetext{
${ }^{303}$ MÜSSNICH, Francisco Antunes Maciel; LOBÃO MELO, Vitor de Britto. Análise Prática e Considerações sobre a realidade e a aplicação das medidas de proteção à tomada de controle nos estatutos sociais das companhias abertas brasileiras (Brazilian Pills). In: SILVA, Alexandre Couto (Coord.). Direito Societário - Estudos sobre a lei de sociedades por ações. 2013. Editora Saraiva. Disponível em: <http://www.bmalaw.com.br/arquivos/Artigos/DIREITO\%20SOCIET\%C3\%81RIO\%20\%20ESTUDOS\%20SOBRE\%20A\%20LEI\%20DE\%20SOCIEDADES\%20POR\%20A\%C3\%87\% C3\%95ES.PDF>. Acesso em: 13/05/2016. p. 266-267.

304 "Some commentators have suggested that the threats posed by hostile offers be categorized into not two but three types: "(i) opportunity loss . . . [where] a hostile offer might deprive target shareholders of the opportunity to select a superior alternative offered by target management [or, we would add, offered by another bidder]; (ii) structural coercion, . . . the risk that disparate treatment of non-tendering shareholders might distort shareholders' tender decisions; and . . . (iii) substantive coercion, ... . the risk that shareholders will mistakenly accept an underpriced offer because they disbelieve management's representations of intrinsic value." The recognition of substantive coercion, the authors suggest, would help guarantee that the Unocal standard becomes an effective intermediate standard of review. Gilson \& Kraakman, Delaware's Intermediate Standard for Defensive Tactics: Is There Substance to Proportionality Review?, 44 The Business
} 
que forçam a administração a manter padrões altos de desempenho. E ainda, permitem a entrada de recursos e de novos investidores em companhias ainda em fase de desenvolvimento, permitindo assim sua expansão e, consequentemente, a do mercado em que atuam.

Por fim, sobre isso, vale destacar as seguintes ponderações bastante pertinentes de JENSEN sobre as ofertas públicas para a tomada de controle e sua importância para o mercado:

The takeover market also provides a unique, powerful, and impersonal mechanism to accomplish the major restructuring and redeployment of assets continually required by changes in technology and consumer preferences. Recent changes occurring in the oil industry provide a good example.

Scientific evidence indicates that activities in the market for corporate control almost uniformly increase efficiency and shareholders' wealth. Yet there is an almost continuous flow of unfavorable publicity and calls for regulation and restriction of unfriendly takeovers. Many of these appeals arise from managers who want protection from competition for their jobs and others who desire more controls on corporations. The result, in the long run, may be a further weakening of the corporation as an organizational form and a reduction in human welfare. ${ }^{305}$

Lawyer, 247, 267 (1989)". (Paramount Communications, Inc. v. Time, Inc. 571 A.2d 1140, Delaware, 1990, Rel. Horsey. Nota de rodapé n 17).

305 JENSEN, Michael C. Takeovers: Folklore and Science. Harvard Business Review. Nov-Dec 1984. p. 27. Disponível em: <http://papers.ssrn.com/sol3/papers.cfm?abstract_id=350425>. Acesso em: 10/03/2016. 


\section{CONCLUSÃO}

A partir da análise doutrinária e jurisprudencial, tanto brasileira como norte-americana, bem como da pesquisa empírica realizada por este trabalho, conclui-se, primeiramente, que a realidade do mercado brasileiro ainda é marcada pelo fenômeno da concentração acionária. Diversas companhias brasileiras possuem controle definido e ainda assim adotam mecanismos de proteção em seus estatutos sociais, a fim de evitar a entrada de um novo controlador. Nos Estados Unidos, no entanto, a realidade é diferente. A maioria das companhias norte-americanas possuem capital disperso e, por isso, acabam sendo controladas, não pelos acionistas, mas pelos próprios administradores.

Não obstante a isso, a simples migração, ainda que de forma embrionária, de companhias brasileiras para estruturas de capital disperso já representa a quebra de um paradigma no Brasil, suficiente para alertar o possível surgimento de um mercado para aquisições hostis de controle, já vivenciado nos Estados Unidos, sobretudo, na década de 1980, caso a tendência do fenômeno da dispersão acionária se concretize.

Entende-se que as medidas de proteção, de uma forma geral, devem sim ser permitidas no Brasil, mas não da forma como vêm sendo adotadas, impondo ônus absurdos e preços abusivos aos acionistas e eventuais ofertantes. Tais medidas não devem ser adotadas com o único e exclusivo intento de impedir/impossibilitar eventual tomada de controle que, muitas vezes, podem ser benéficas à companhia e seus acionistas.

Os mecanismos de proteção, em geral, devem ser opostos contra reais ameaças à companhia e seus negócios, e devem ser razoáveis e proporcionais à ameaça apresentada, em linha com o que já ocorre nos Estados Unidos. Além disso, devem ser utilizados de forma a proteger os acionistas contra ofertas coercitivas, ou então a alcançar um melhor preço de oferta, por meio de negociação, dentre outras finalidades que visem os melhores interesses da companhia e de seus acionistas. 
Além disso, a adoção das medidas de proteção, quaisquer que sejam, devem ser feitas com o mínimo de reflexão com respeito a sua legalidade e adequação à realidade de cada mercado, e cada companhia. O que não pode haver é a inserção automática de cláusulas padronizadas que impõem condições absurdas aos acionistas e potenciais ofertantes, tornando quase impossível a aquisição de controle, como é o caso das Brazilian pills, e que podem acabar gerando o entrincheiramento da administração e/ou de seus controladores, haja vista a quantidade de companhias com controle definido que adotam tais medidas.

Além disso, a intenção do entrincheiramento se torna ainda mais flagrante no caso de companhias que adotam cláusulas pétreas visando aplicar sanções desproporcionais aos acionistas que votarem pela alteração ou exclusão da Brazilian pill. Isso demonstra, de forma ainda mais evidente, o objetivo dos que possuem o poder de domínio da companhia de se resguardarem contra a tomada de controle por parte de um terceiro interessado, ainda que essa aquisição seja do interesse dos acionistas.

Percebe-se, com isso, o desvirtuamento da finalidade originalmente proposta pelos mecanismos idealizados nos Estados Unidos que foram incorporados no Brasil, muitas vezes, sem as devidas reflexões/adequações. Nota-se, por meio dos casos analisados, que tanto as medidas de proteção quanto as ofertas públicas hostis são reconhecidas e aceitas nos Estados Unidos e no Brasil, a depender do caso concreto.

Especificamente nos Estados Unidos, as aquisições hostis e os mecanismos de proteção já foram exaustivamente analisados pelos tribunais. Os casos paradigmáticos estudados demonstram, em síntese, que (i) as medidas de defesa devem visar os melhores interesses dos acionistas; (ii) as ofertas hostis não necessariamente são prejudiciais às companhias e seus acionistas; e (iii) os administradores devem observar seus deveres fiduciários quando da adoção de uma medida de proteção, ou quando da rejeição ou aceitação de uma oferta hostil. 
No Brasil, no entanto, a experiência com relação à matéria no mercado ainda é muito incipiente, e a jurisprudência sobre o tema ainda é escassa e, por isso, faz-se necessário recorrer, muitas vezes, à doutrina e jurisprudência estrangeira, sobretudo, de mercados mais experientes em relação às aquisições hostis e mecanismos de proteção.

Atualmente, o assunto merece especial atenção, sobretudo, por parte da CVM, principalmente, no que diz respeito à legalidade e pertinência das Brazilian pills, que vêm sendo adotadas pelas mais diversas companhias brasileiras, com controle definido ou não.

Por fim, encerra-se este trabalho propondo à CVM a adoção de um posicionamento mais sólido em relação aos mecanismos de proteção contra a tomada hostil de controle, sobretudo, para orientar o mercado, tendo em vista a insegurança jurídica enfrentada com relação à matéria no Brasil.

Sendo assim, sugere-se à CVM que:

(i) coíba as cláusulas excessivamente onerosas previstas nas Brazilian pills e determine sua revisão, de forma a estabelecer preços razoáveis para a realização da OPA estatutária;

(ii) edite ato normativo regulamentando os mecanismos de proteção no Brasil ou parecer de orientação que possa servir de guia para as companhias abertas e seus administradores sobre o posicionamento da CVM com relação à matéria; $\mathrm{e}$

(iii) estabeleça que as companhias abertas não poderão prever em seus estatutos sociais disposições que: a) estabeleçam quórum qualificado para a deliberação de matérias que devam ser submetidas à assembleia geral de acionistas, haja vista a ilegalidade de tais disposições, conforme o previsto no artigo $129, \S 1^{\circ}$ c/c 136 da Lei das S.A.; e b) impeçam o exercício de voto favorável ou imponham ônus aos acionistas que votarem favoravelmente à supressão de ou alteração de cláusulas estatutárias. ${ }^{306}$

\footnotetext{
306 O Regulamento de Listagem do Novo Mercado, por exemplo, adotou essa regra em seu item 3.1.2. A previsão representa um avanço, pois acaba com a existência de cláusulas pétreas e suspensão de direitos de acionistas dos estatutos sociais de companhias listadas no segmento.
} 


\section{BIBLIOGRAFIA}

A BEAUTIFUL MIND. Direção de Ron Howard. Estados Unidos: Universal Pictures/DreamWorks Pictures/Imagine Entertainment. 2001. A versão brasileira foi intitulada "Uma mente brilhante".

Anuário de Governança Corporativa das Companhias Abertas 2015-2016. Revista Capital Aberto. Ano 6. № 43.

APPENDINO, Fábio. O Instituto do Direito de Voto em um Contexto de Dispersão Acionária. In: CASTRO, Rodrigo R. Monteiro de; MOURA AZEVEDO, Luís André N. de (Coord.). Poder de Controle e Outros Temas de Direito Societário e Mercado de Capitais. São Paulo: Quartier Latin, 2010. p. 437-473.

BERLE, Adolf; MEANS, Gardiner. The Modern Corporation and Private Property. Revised Edition. 1967. First Edition 1932. New York: Harcourt, Brace \& World, Inc. 380 p.

BORBA, José Edwaldo Tavares. Direito societário. $13^{\mathrm{a}}$ ed. Rio de Janeiro: Renovar, 2012. 595 p.

CAMPOS, Luiz Antonio de Sampaio. Deveres e Responsabilidades. In: LAMY FILHO, Alfredo; BULHÕES PEDREIRA, José Luiz. Direito das Companhias. Volume I. Rio de Janeiro: Forense, 2009. p. 1084-1262.

CARVAlHOSA, Modesto. As Poison Pills Estatutárias na Prática Brasileira - Alguns Aspectos de sua Legalidade. In: CASTRO, Rodrigo R. Monteiro de; ARAGÃO, Leandro Santos de (Coord.). Direito Societário Desafios Atuais. São Paulo: Quartier Latin, 2009. p. 19-29.

CASTRO, Marcílio Moreira de. Dicionário de direito, economia e contabilidade: português-inglês/inglês-português. $4^{\mathrm{a}}$ ed. Rio de Janeiro: Forense, 2013. 827 p.

CHEDIAK, Julian Fonseca Peña. A reforma do mercado de valores mobiliários. In: LOBO, Jorge (Coord.). Reforma da Lei das Sociedades Anônimas. Rio de Janeiro: Forense, 2002. p. 525-551. 
CHEDIAK, Julian Fonseca Peña. O Modelo ANBID: Autorregulação Voluntária em Complemento à Regulação Estatal. Rio de Janeiro, abril de 2009. $31 \mathrm{p}$.

CLARK, Robert Charles. Corporate Law. Boston/Toronto: Little, Brown and Company, 1986. 837 p.

COMPARATO, Fábio Konder. O poder de controle na sociedade anônima. $6^{\mathrm{a}}$ ed. Rio de Janeiro: Editora Forense, 2014. 502 p.

COSTA, Len. The Perfect Pill. A small innovation that transformed corporate takeovers. Legal Affairs. Abril de 2005. Disponível em: <http://www.legalaffairs.org/issues/March-April2005/toa_costa_marapr05.msp>. Acesso em: 07/02/2016.

CVM. Processo Administrativo CVM N RJ2013/10913. Voto da Diretora Ana Dolores Moura Carneiro de Novaes. 25/03/2014.

Decisão do Colegiado da CVM de 09/09/2010. Disponível em: <http://www.cvm.gov.br/decisoes/2010/20100909_R1/20100909_D09.html >. Acesso em: 14/02/2016.

Decisão do Colegiado de 14/04/2009. Disponível em: <http://www.cvm.gov.br/decisoes/2009/20090414_R1/20090414_D04.html >. Acesso em: 03/07/2016.

Decisão do Colegiado da CVM de 25/09/2006. CVM, Processo Administrativo $\mathrm{n}^{\circ}$ RJ 2006-6209. Rel. Wladimir Castelo Branco Castro. Disponível em: <http://www.cvm.gov.br/export/sites/cvm/decisoes/anexos/0003/52560.pdf>. Acesso em: 14/02/2016.

DUBEUX, Julio Ramalho. A Comissão de Valores Mobiliários e os principais instrumentos regulatórios do mercado de capitais brasileiro. Porto Alegre: Sérgio Antonio Fabris Ed., 2006. 112 p.

EIZIRIK, Nelson. A legalidade das poison pills adotadas pelas companhias brasileiras. In: Direito societário - estudos e pareceres. São Paulo: Quartier Latin, 2015. p. 600-602. 
EIZIRIK, Nelson. A Lei das S/A Comentada. Volume I. São Paulo: Quartier Latin, 2011.735 p.

EIZIRIK, Nelson. A Lei das S/A Comentada. Volume III. São Paulo: Quartier Latin, 2011.640 p.

EIZIRIK, Nelson; GAAL, Ariádna B.; PARENTE, Flávia; HENRIQUES, Marcus Freitas. Mercado de Capitais - Regime Jurídico. $3^{\text {a }}$ ed. Rio de Janeiro: Renovar, 2011. 660 p.

FLOM, Joseph H. Mergers \& Acquisitions: The Decade in Review. University of Miami Law Review. 2000. Disponível em: $<$ http://repository.law.miami.edu/cgi/viewcontent.cgi?article=1593\&contex t=umlr $>$. Acesso em: 09/05/2016. p. 753-781.

FRIEDENBERG, Ellen S. Jaws III: The impropriety of shark-repellent amendments as a takeover defense. Disponível em: $<$ http://www.djcl.org/wp-content/uploads/2014/07/Jaws-III-THEIMPROPRIETY-OF-SHARK-REPELLENT-AMENDMENTS-AS-ATAKEOVER-DEFENSE1.pdf>. Acesso em: 07/05/2016.

GARNER, Bryan A. (editor in chief). Black's Law Dictionary. 3a ed. Thomson/West, 2006. 810 p.

GLADWELL, Malcolm. Fora de Série - Outliers. Tradução de Ivo Korytowski. Rio de Janeiro: Sextante, 2008. 283 p.

GORGA, Erica. Changing the Paradigm of Stock Ownership from Concentrated towards Dispersed Ownership: Evidence from Brazil and Consequences for Emerging Countries. Northwestern Journal of International Law \& Business. 2009. Disponível em: $<$ http://scholarlycommons.law.northwestern.edu/cgi/viewcontent.cgi?article $=1689 \&$ context $=$ jilb $>$. Acesso em: 16/05/2016. p. 439-554.

JENSEN, Michael C. Jensen. Takeovers: Their Causes and Consequences. Journal of Economic Perspectives, Winter 1988, Vol. 2, No. pp. 21-48. Disponível em: 
<http://papers.ssrn.com/sol3/papers.cfm?abstract_id=173455>. Acesso em: 07/02/2016.

JENSEN, Michael C. Takeovers: Folklore and Science. Harvard Business Review. Nov-Dec 1984. 31 p. Disponível em: <http://papers.ssrn.com/sol3/papers.cfm?abstract_id=350425>. Acesso em: 10/03/2016.

LAMY FILHO, Alfredo; BULHÕES PEDREIRA, José Luiz. Estrutura da Companhia. In: LAMY FILHO, Alfredo; BULHÕES PEDREIRA, José Luiz (Coord.). Direito das Companhias. Volume I. Rio de Janeiro: Forense, 2009. p. $775-870$.

LIPTON, Martin; ROWE, Paul K. Pills, Polls, and Professors: A Reply to Professor Gilson. The Delaware Journal of Corporate Law, Vol. 27, No. 1, pp. $1-55,2002$. p. $14-15$

MANKIW, N. Gregory. Tradução de Allan Vidigal Hastings, Elisete Paes e Lima. Introdução à Economia. Título original: Principles of economics. 5. ed. norte-americana. São Paulo: Cengage Learning, 2009. 838 p.

MARTINS NETO, Carlos. Dispersão Acionária, Tomada Hostil de Controle e Poison Pills: Breves Reflexões. Dez. 2009. Disponível em: <http://www.bocater.com.br/UPLOAD/noticias/564d93f37f654.pdf>. Acesso em: 08/02/2016. 58 p.

MEMO/SRE/GER-1/No 214/2008 de 17/09/2008. Disponível em: <http://www.cvm.gov.br/export/sites/cvm/noticias/anexos/2008/200810061-memo-sre.pdf>. Acesso em: 20/04/2016.

Memorando do Diretor Marcos Barbosa Pinto e Diretor Otavio Yazbek, 14.04.2008. Disponível em: <http://www.cvm.gov.br/export/sites/cvm/decisoes/anexos/0005/64910.pdf>. Acesso em: 13/02/2016.

Moran v. Household Int'1 (500 A.2d 1346, Delaware, 1985, Rel. MecNeilly). 
MUNHOZ, Eduardo Secchi. Desafios do Direito Societário Brasileiro na Disciplina da Companhia Aberta: Avaliação dos Sistemas de Controle Diluído e Concentrado. In: CASTRO, Rodrigo R. Monteiro de; ARAGÃO, Leandro Santos de (Coord.). Direito Societário - Desafios Atuais. São Paulo: Quartier Latin, 2009. p. 119-155.

MUNIZ, Ian de Porto Alegre. Fusões e Aquisições - Aspectos Fiscais e Societários. 2a ed. São Paulo: Quartier Latin, 2011. 350 p.

MÜSSNICH, Francisco Antunes Maciel. A utilização desleal de informações privilegiadas - "Insider Trading" - no Brasil e nos Estados Unidos. Revista de direito mercantil, industrial, econômico e financeiro $\mathrm{n}^{\circ}$ 34, Abril/Junho de 1979, Ano XVIII. p. 31-51.

MÜSSNICH, Francisco Antunes Maciel; HENRIQUE PERES, Fábio. Administração deve colaborar para o melhor uso das poison pills. Out. 2008.

em:

<http://www.bmalaw.com.br/arquivos/Artigos/Numero\%2025.pdf>. Acesso em: 13/02/2016.

MÜSSNICH, Francisco Antunes Maciel; LOBÃO MELO, Vitor de Britto. Análise Prática e Considerações sobre a realidade e a aplicação das medidas de proteção à tomada de controle nos estatutos sociais das companhias abertas brasileiras (Brazilian Pills). In: SILVA, Alexandre Couto (Coord.). Direito Societário - Estudos sobre a lei de sociedades por ações. 2013. Editora Saraiva. Disponível em: $<$ http://www.bmalaw.com.br/arquivos/Artigos/DIREITO\%20SOCIET\%C3 $\% 81 \mathrm{RIO} \% 20-$

\%20ESTUDOS\%20SOBRE\%20A\%20LEI\%20DE\%20SOCIEDADES\%20 POR\%20A\%C3\%87\%C3\%95ES.PDF>. Acesso em: 13/05/2016. p. 253278.

NASCIMENTO, João Pedro Barroso do. Medidas Defensivas à Tomada de Controle de Companhias. São Paulo: Quartier Latin, 2011. 285 p. 
NASH, John. Non-cooperative games. Annals of Mathematics. Vol. 54, No., September, 1951. p. 286-295.

"No Mas" to "Just Say No"? David Fox, Kirkland \& Ellis LLP. Disponível em: <https://corpgov.law.harvard.edu/2010/03/20/no-mas-to-just-say-no/>. Acesso em: 08/02/2016.

O mercado de valores mobiliários brasileiro / Comissão de Valores Mobiliários. 3. Ed. Rio de Janeiro: Comissão de Valores Mobiliários, 2014. $370 \mathrm{p}$.

O que é a CVM? Disponível em: $<$ http://www.investidor.gov.br/menu/Menu_Investidor/a_cvm/ACVM.html >. Acesso em: 09/02/2016.

Ora, pílulas. Istoé Dinheiro. Julho de 2009. Disponível em: $<$ http://www.istoedinheiro.com.br/noticias/dinheiro-em-acao/20090715/orapilulas/12568.shtml>. Acesso em: 08/02/2016.

OSÓRIO, José Diogo Horta. Da Tomada do Controlo de Sociedades (takeovers) por Leveraged Buy-Out e sua Harmonização com o Direito Português. Coimbra: Almedina, 2001. p. 9. Apud: NASCIMENTO, João Pedro Barroso do. Medidas Defensivas à Tomada de Controle de Companhias. São Paulo: Quartier Latin, 2011. p. 102.

OTHER PEOPLE'S MONEY. Direção de Norman Jewison. Estados Unidos: Warner Bros. 1991. 1 DVD (101 minutos), Color.

Paramount Communications v. Qvc Network (637 A.2d 34, Delaware, 1994, Rel. Veasey).

Paramount Communications, Inc. v. Time, Inc. (571 A.2d 1140, Delaware, 1990, Rel. Horsey).

Parecer de Orientação CVM $\mathrm{n}^{\circ}$ 36. Disponível em: <http://www.cvm.gov.br/legislacao/pare/pare036.html>. Acesso em: $14 / 02 / 2016$.

PEREIRA, Atademes Branco; TREIGER, José Marcos. Por que abrir o capital? In: SIQUEIRA, Marcelo; PEREIRA, Atademes Branco; 
TREIGER, José Marcos (Coord.). Brasil S/A: Guia de Acesso ao Mercado de Capitais para Companhias Brasileiras. Rio de Janeiro: RR Donnelley Financial Comunicação Corporativa, 2014. p. 15-21.

PINHEIRO DOS SANTOS, Alexandre. Mercado de capitais - Regime sancionador. MEDINA OSÓRIO, Fábio; SOTTO MAYOR WELLISCH, Julya. PINHEIRO DOS SANTOS, Alexandre (Coord.). Editora Saraiva, 2012. 295 p.

PRADO, Roberta Nioac. Desconcentração do Poder de Controle e Poison Pills: Evolução no Mercado de Capitais Brasileiro. In: CASTRO, Rodrigo R. Monteiro de; MOURA AZEVEDO, Luís André N. de (Coord.). Poder de Controle e Outros Temas de Direito Societário e Mercado de Capitais. São Paulo: Quartier Latin, 2010. p. 375-410.

PRETTY WOMAN. Direção de Garry Marshall; Produção de Arnon Milchan. Estados Unidos: Touchstone Pictures. 1990. 1 DVD (115 minutos), Color.

Processo Administrativo Sancionador CVM n RJ 2005/1443. Rel. Pedro Oliva Marcilio de Sousa.

REQUIÃO, Rubens. Curso de direito comercial. $2^{\circ}$ volume. 31. ed. São Paulo: Saraiva, 2014. 861 p.

Revlon Inc. v. Macandrews \& Forbes Holdings, Inc. (506 A.2d 173, Delaware, 1986, Rel. Moore).

RIBSTEIN, Larry E. Imagining Wall Street. Virginia Law and Business Review, Vol. 1, p. 165, 2006. Disponível em: $<$ http://papers.ssrn.com/sol3/papers.cfm?abstract_id=771724\#\#>. Acesso em: 10/03/2016.

SHIGUEMATSU, Plínio José Lopes. Mecanismos de proteção $e$ estratégias de defesa em tomadas hostis de controle. In: CASTRO, Rodrigo R. Monteiro de; ARAGÃO, Leandro Santos de (Coord.). Direito Societário - Desafios Atuais. São Paulo: Quartier Latin, 2009. p. 389-440. 
SILVEIRA LOBO, Carlos Augusto da. Oferta Pública para Aquisição de Controle de Companhia Aberta. In: LAMY FILHO, Alfredo; BULHÕES PEDREIRA, José Luiz. Direito das Companhias. Volume II. Rio de Janeiro: Forense, 2009. p. 2031-2044.

STRINE JR, Leo E. Can We Do Better by Ordinary Investors? A Pragmatic Reaction to the Dueling Ideological Mythologists of Corporate Law. In: Columbia Law Review. vol. 114, p. 449-502. Disponível em: <http://columbialawreview.org/wp-content/uploads/2014/03/Strine-L..pdf>. Acesso em: 24/03/2016.

SUBRAMANIAN, Guhan. Bargaining in the Shadow of Takeover Defenses. Yale Law Journal, Vol. 113, Issue 3. p. 621-686, December, 2003. Disponível em: $<$ http://papers.ssrn.com/sol3/papers.cfm?abstract_id=442721>. Acesso em: 10/03/2016.

SUITS. Direção de Kevin Bray. Estados Unidos: Universal Pictures. 2011. Season 1, Episode 7.

TAVARES GUERREIRO, José Alexandre. Sobre o poder disciplinar da CVM. Revista de direito mercantil, industrial, econômico e financeiro. São Paulo: Revista dos Tribunais. v. 43. p. 64-78, jul/set, 1981. p. 64-78.

The Delaware Way: Deference to the Business Judgment of Directors Who Act Loyally and Carefully. Disponível em: <http://corplaw.delaware.gov/eng/delaware_way.shtml>. Acesso em: 08/02/2016.

The Investor's Advocate: How the SEC Protects Investors, Maintains Market Integrity, and Facilitates Capital Formation. Jun. 2013. Disponível em: <https://www.sec.gov/about/whatwedo.shtml>. Acesso em: 08/02/2016.

The Role of the SEC. Disponível em: $<$ https://www.investor.gov/introduction-markets/role-sec $>$. Acesso em: 08/02/2016. 
The Williams Act: a Truly "Modern" Assessment. Disponível em: $<$ http://corpgov.law.harvard.edu/wp-content/uploads/2011/10/TheWilliams-Act-A-Truly-Modern-Assessment.pdf>. Acesso em: 08/02/2016. TOLEDO, Paulo Fernando Campos Salles de. Poison pill: Modismo ou Solução? In: CASTRO, Rodrigo R. Monteiro de; ARAGÃO, Leandro Santos de (Coord.). Direito Societário - Desafios Atuais. São Paulo: Quartier Latin, 2009. p. 157-176.

Unitrin, Inc. v. Am. Gen. Corp. (651 A.2d 1361, Delaware, 1995, Rel. Holland).

Unocal Corp. v. Mesa Petroleum Co. (493 A.2d 946, Delaware, 1985, Rel. Moore).

VALVERDE, Trajano de Miranda. Sociedades por Ações. Vol. II. $3^{\mathrm{a}}$ edição. Rio de Janeiro: Forense, 1959. 462 p.

VILARINHO BORGES, Leandro; PETRI BERNARDES, Lucas; COMETTI, Marcelo Tadeu; NAKAYAMA, Wilson. A poison pill brasileira: proteção da dispersão acionária ou reforço do poder de controle? Revista de direito mercantil, industrial, econômico e financeiro. Ano L. julho-dezembro/2011. Editora Malheiros. p. 231-244.

WALL STREET. Direção de Oliver Stone; Produção de Edward R. Pressman. Estados Unidos: Twentieth Century Fox Film Corporation. 1987. 1 DVD (125 minutos), Color.

Why Businesses Choose Delaware. Disponível em: $<$ http://corplaw.delaware.gov/eng/why_delaware.shtml>. Acesso em: 08/02/2014.

ZANINI, Carlos Klein. A Poison Pill Brasileira: Desvirtuamento, antijuridicidade e ineficiência. In: ADAMEK, Marcelo Vieira Von. (Coord.). Temas de Direito Societário e Empresarial Contemporâneos. São Paulo: Malheiros, 2011. p. 256-277. 


\section{ANEXO I}

TABELA DE COMPANHIAS DO NOVO MERCADO

\begin{tabular}{|c|c|c|c|c|}
\hline $\mathbf{N}^{\circ}$ & Companhia & $\begin{array}{l}\text { Controle } \\
\text { definido? }\end{array}$ & $\begin{array}{l}\text { Brazilian } \\
\text { pill? }\end{array}$ & $\begin{array}{l}\text { Cláusula } \\
\text { pétrea? }\end{array}$ \\
\hline 1 & Aliansce Shopping Centers S.A. & Sim & Sim & Não \\
\hline 2 & GAEC Educação S.A. & Sim & Sim & Não \\
\hline 3 & Arezzo Indústria e Comércio S.A. & Sim & Não & Não \\
\hline 4 & Arteris S.A. & Sim & Sim & Não \\
\hline 5 & B2W - Companhia Digital & Sim & Sim & Não \\
\hline 6 & BB Seguridade Participações S.A. & Sim & Não & Não \\
\hline 7 & Biosev S.A. & Sim & Sim & Não \\
\hline 8 & BM\&FBovespa S.A. & Não & Sim & Não \\
\hline 9 & Brasil Brokers Participações S.A. & Não & Sim & Não \\
\hline 10 & $\begin{array}{c}\text { Brasil Insurance Participações e Adm. } \\
\text { S.A. }\end{array}$ & Não & Sim & Não \\
\hline 11 & BR Malls Participações S.A. & Não & Sim & Não \\
\hline 12 & Brasil Pharma S.A. & Sim & Sim & Não \\
\hline 13 & BR Properties S.A. & Não & Sim & Não \\
\hline 14 & Banco do Brasil S.A. & Sim & Não & Não \\
\hline 15 & $\begin{array}{c}\text { Brasilagro - Cia Bras. de Prop. } \\
\text { Agrícolas }\end{array}$ & Sim & Sim & Sim \\
\hline 16 & BRF S.A. & Não & Sim & Não \\
\hline 17 & CCR S.A. & Sim & Não & Não \\
\hline 18 & CCX Carvão da Colômbia S.A. & Não & Não & Não \\
\hline 19 & CETIP S.A. - Mercados Organizados & Não & Sim & Não \\
\hline 20 & Cia Hering & Não & Sim & Não \\
\hline 21 & Cielo S.A. & Sim & Não & Não \\
\hline 22 & Cia de Saneamento de Minas Gerais & Sim & Não & Não \\
\hline 23 & Cosan S.A. Indústria e Comércio & Sim & Não & Não \\
\hline 24 & Cosan Logística S.A. & Sim & Não & Não \\
\hline 25 & CPFL Energia S.A. & Sim & Não & Não \\
\hline 26 & CPFL Energias Renováveis S.A. & Sim & Não & Não \\
\hline 27 & $\begin{array}{c}\text { CR2 Empreendimentos Imobiliários } \\
\text { S.A. }\end{array}$ & Não & Não & Não \\
\hline 28 & CSU Cardsystem S.A. & Sim & Não & Não \\
\hline 29 & $\begin{array}{c}\text { CVC Brasil Operadora e Ag. de } \\
\text { Viagens S.A. }\end{array}$ & Sim & Não & Não \\
\hline
\end{tabular}




\begin{tabular}{|c|c|c|c|c|}
\hline 30 & $\begin{array}{l}\text { Cyrela Commercial Propert. S.A. } \\
\text { Empr. Part. }\end{array}$ & Sim & Sim & Sim \\
\hline 31 & $\begin{array}{l}\text { Cyrela Brazil Realty S.A. Empreend. e } \\
\text { Part. }\end{array}$ & Sim & Não & Não \\
\hline 32 & Direcional Engenharia S.A. & Sim & Sim & Não \\
\hline 33 & Duratex S.A. & Sim & Não & Não \\
\hline 34 & $\begin{array}{c}\text { Ecorodovias Infraestrutura e Logística } \\
\text { S.A. }\end{array}$ & Sim & Não & Não \\
\hline 35 & Embraer S.A. & Não & Sim & Não \\
\hline 36 & EDP - Energias do Brasil S.A. & Sim & Não & Não \\
\hline 37 & Eneva S.A. & Não & Não & Não \\
\hline 38 & Equatorial Energia S.A. & Não & Não & Não \\
\hline 39 & Estácio Participações S.A. & Não & Sim & Não \\
\hline 40 & Eternit S.A. & Não & Não & Não \\
\hline 41 & $\begin{array}{c}\text { Even Construtora e Incorporadora } \\
\text { S.A. }\end{array}$ & Não & Não & Não \\
\hline 42 & EZ TEC Empreend. e Participações S.A. & Sim & Sim & Sim \\
\hline 43 & Fertilizantes Heringer S.A. & Sim & Sim & Sim \\
\hline 44 & Fibria Celulose S.A. & Sim & Sim & Não \\
\hline 45 & Fleury S.A. & Não & Não & Não \\
\hline 46 & Gafisa S.A. & Não & Sim & Não \\
\hline 47 & General Shopping Brasil S.A. & Sim & Sim & Sim \\
\hline 48 & Grendene S.A. & Sim & Não & Não \\
\hline 49 & Helbor Empreendimentos S.A. & Sim & Sim & Sim \\
\hline 50 & Hypermarcas S.A. & Sim & Sim & Não \\
\hline 51 & Ideiasnet S.A. & Não & Não & Não \\
\hline 52 & $\begin{array}{c}\text { Iguatemi Empresa de Shopping } \\
\text { Centers S.A. }\end{array}$ & Sim & Não & Não \\
\hline 53 & $\begin{array}{l}\text { International Meal Company } \\
\text { Alimentação S.A. }\end{array}$ & Sim & Não & Não \\
\hline 54 & Industrias Romi S.A. & Sim & Sim & Sim \\
\hline 55 & lochpe-Maxion S.A. & Sim & Sim & Sim \\
\hline 56 & JBS S.A. & Sim & Sim & Não \\
\hline 57 & JHSF Participações S.A. & Sim & Sim & Não \\
\hline 58 & JSL S.A. & Sim & Sim & Não \\
\hline 59 & Kroton Educacional S.A. & Não & Não & Não \\
\hline 60 & $\begin{array}{l}\text { Restoque Comércio e Conf. de Roupas } \\
\text { S.A. }\end{array}$ & Não & Não & Não \\
\hline 61 & Light S.A. & Não & Não & Não \\
\hline 62 & Linx S.A. & Sim & Sim & Não \\
\hline 63 & Localiza Rent a Car S.A. & Sim & Sim & Não \\
\hline 64 & Companhia de Locação das Américas & Sim & Sim & Não \\
\hline
\end{tabular}




\begin{tabular}{|c|c|c|c|c|}
\hline 65 & Log-In Logística Intermodal S.A. & Não & Sim & Sim \\
\hline 66 & Marisa Lojas S.A. & Sim & Sim & Não \\
\hline 67 & Lojas Renner S.A. & Não & Sim & Sim \\
\hline 68 & LPS Brasil Consultoria de Imóveis S.A. & Não & Sim & Sim \\
\hline 69 & Lupatech S.A. & Não & Sim & Não \\
\hline 70 & $\begin{array}{l}\text { M. Dias Branco S.A. Ind. Com. de } \\
\text { Alimentos }\end{array}$ & Sim & Não & Não \\
\hline 71 & Magazine Luiza S.A. & Sim & Sim & Não \\
\hline 72 & Magnesita Refratários S.A. & Sim & Não & Não \\
\hline 73 & Marfrig Global Foods S.A. & Sim & Não & Não \\
\hline 74 & Mahle-Metal Leve S.A. & Sim & Não & Não \\
\hline 75 & Metalfrio Solutions S.A. & Não & Não & Não \\
\hline 76 & $\begin{array}{c}\text { Mills Estruturas e Serviços de } \\
\text { Engenharia S.A. }\end{array}$ & Sim & Sim & Não \\
\hline 77 & Minerva S.A. & Sim & Sim & Não \\
\hline 78 & MMX Mineração e Metálicos S.A. & Sim & Não & Não \\
\hline 79 & MRV Engenharia e Participações S.A. & Sim & Sim & Não \\
\hline 80 & Multiplus S.A. & Sim & Não & Não \\
\hline 81 & Natura Cosméticos S.A. & Sim & Sim & Não \\
\hline 82 & Odontoprev S.A. & Sim & Sim & Sim \\
\hline 83 & Óleo e Gás Participações S.A. & Sim & Não & Não \\
\hline 84 & OSX Brasil S.A. & Sim & Não & Não \\
\hline 85 & $\begin{array}{l}\text { Ouro Fino Saúde Animal Participações } \\
\text { S.A. }\end{array}$ & Sim & Não & Não \\
\hline 86 & Paranapanema S.A. & Não & Não & Não \\
\hline 87 & FPC Par Corretora de Seguros S.A. & Sim & Sim & Não \\
\hline 88 & $\begin{array}{c}\text { PDG Realty S.A. Empreend. e } \\
\text { Participações }\end{array}$ & Não & Não & Não \\
\hline 89 & Petro rio S.A. & Não & Não & Não \\
\hline 90 & Pomifrutas S.A. & Sim & Não & Não \\
\hline 91 & Porto Seguro S.A. & Sim & Sim & Não \\
\hline 92 & PBG S.A. & Sim & Sim & Não \\
\hline 93 & Positivo Informática S.A. & Sim & Sim & Sim \\
\hline 94 & $\begin{array}{c}\text { Profarma Distrib Prod Farmacêuticos } \\
\text { S.A. }\end{array}$ & $\operatorname{Sim}$ & Sim & Não \\
\hline 95 & Prumo Logística S.A. & Sim & Não & Não \\
\hline 96 & QGEP Participações S.A. & Sim & Não & Não \\
\hline 97 & Qualicorp S.A. & Sim & Não & Não \\
\hline 98 & Raia Drogasil S.A. & Sim & Sim & Não \\
\hline 99 & Rodobens Negócios Imobiliários S.A. & Sim & Sim & Não \\
\hline 100 & Rossi Residencial S.A. & Sim & Sim & Não \\
\hline 101 & Rumo Logística Operadora & Sim & Sim & Não \\
\hline
\end{tabular}




\begin{tabular}{|c|c|c|c|c|}
\hline & Multimodal S.A. & & & \\
\hline 102 & Cia Saneamento Básico Est. São Paulo & Sim & Não & Não \\
\hline 103 & $\begin{array}{c}\text { São Carlos Empreend e Participações } \\
\text { S.A. }\end{array}$ & Sim & Sim & Não \\
\hline 104 & São Martinho S.A. & Não & Sim & Não \\
\hline 105 & Ser Educacional S.A. & Sim & Não & Não \\
\hline 106 & Sonae Sierra Brasil S.A. & Sim & Não & Não \\
\hline 107 & SLC Agrícola S.A. & Sim & Sim & Não \\
\hline 108 & Smiles S.A. & Sim & Não & Não \\
\hline 109 & Somos Educação S.A. & Não & Não & Não \\
\hline 110 & Springs Global Participações S.A. & Sim & Sim & Não \\
\hline 111 & Tarpon Investimentos S.A. & Sim & Não & Não \\
\hline 112 & Technos S.A. & Não & Sim & Não \\
\hline 113 & Tecnisa S.A. & Sim & Sim & Sim \\
\hline 114 & Tegma Gestão Logística S.A. & Sim & Não & Não \\
\hline 115 & Tempo Participações S.A. & Sim & Não & Não \\
\hline 116 & Tereos Internacional S.A. & Sim & Não & Não \\
\hline 117 & Tim Participações S.A. & Sim & Não & Não \\
\hline 118 & T4F Entretenimento S.A. & Sim & Sim & Não \\
\hline 119 & TOTVS S.A. & Não & Sim & Sim \\
\hline 120 & Tractebel Energia S.A. & Sim & Não & Não \\
\hline 121 & Trisul S.A. & Sim & Sim & Não \\
\hline 122 & TPI - Triunfo Particip. e Invest. S.A. & Sim & Sim & Não \\
\hline 123 & Tupy S.A. & Sim & Sim & Não \\
\hline 124 & Ultrapar Participações S.A. & Não & Sim & Não \\
\hline 125 & Unicasa Indústria de Móveis S.A. & Sim & Não & Não \\
\hline 126 & Vanguarda Agro S.A. & Não & Não & Não \\
\hline 127 & $\begin{array}{l}\text { Valid Sol. e Serv. Seg. Meios Pag. } \\
\text { Ident. S.A. }\end{array}$ & Não & Sim & Sim \\
\hline 128 & Vigor Alimentos S.A. & Sim & Sim & Não \\
\hline 129 & $\begin{array}{c}\text { Viver Incorporadora e Construtora } \\
\text { S.A. }\end{array}$ & Não & Sim & Não \\
\hline 130 & Weg S.A. & Sim & Não & Não \\
\hline
\end{tabular}

\section{FONTES:}

Lista de companhias do Novo Mercado. Disponível em:

$<$ http://www.bmfbovespa.com.br/pt_br/produtos/listados-a-vista-ederivativos/renda-variavel/empresas-listadas.htm>. Acesso em: 20/04/2016.

Estatutos sociais das companhias, bem como o item 15.1/15.2 de seus formulários de referência. Disponível em: 〈http://sistemas.cvm.gov.br/>. Acesso em: 20/04/2016 a 22/04/2016. 